Portland State University

PDXScholar

8-2-1996

\title{
Dramatic Conflict and Historical Reality in Carl Zuckmayer's Hauptmann von Kopenick
}

Craig O. Smith

Portland State University

Follow this and additional works at: https://pdxscholar.library.pdx.edu/open_access_etds

Part of the German Language and Literature Commons Let us know how access to this document benefits you.

Recommended Citation

Smith, Craig O., "Dramatic Conflict and Historical Reality in Carl Zuckmayer's Hauptmann von Kopenick" (1996). Dissertations and Theses. Paper 5107.

https://doi.org/10.15760/etd.6983

This Thesis is brought to you for free and open access. It has been accepted for inclusion in Dissertations and Theses by an authorized administrator of PDXScholar. Please contact us if we can make this document more accessible: pdxscholar@pdx.edu. 


\section{THESIS APPROVAL}

The abstract and thesis of Craig O. Smith for the Master of Arts in German were presented August 2, 1996 and accepted by the thesis committee and the department.

COMMITTEE APPROVALS:

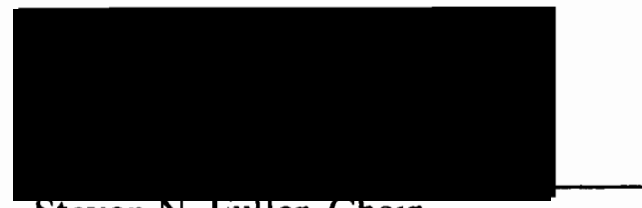

Steven N. Fuller, Chair

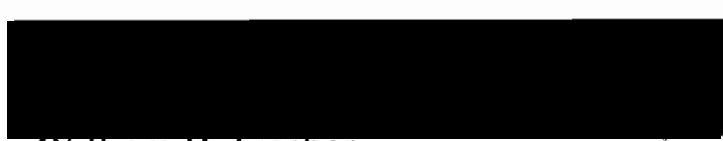

Willam B. Fischer

DEPARTMENT APPROVAL:

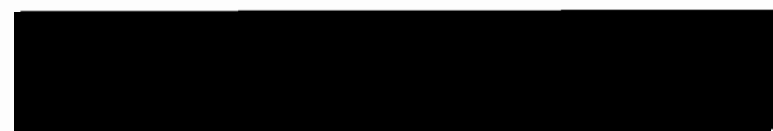

Friedrich E. Schuler

Representative of the Office of Graduate Studies

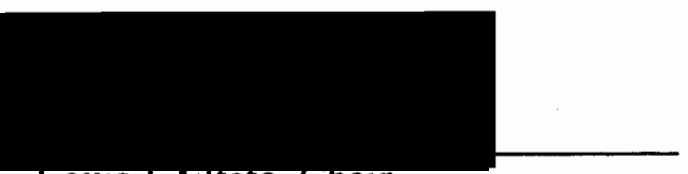

Louis J. Elteto, Chair

Department of Foreign Languages and Literatures

$* * * * * * * * * * * * * * * * * * * * * * * * * * * * * * * * * * * * * * * * * * * * * * * * * * * * * * * * * * * * * * * * * * * * *$

ACCEPTED FOR PORTLAND STATE UNIVERSITY BY THE LIBRARY

by

on

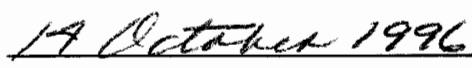




\begin{abstract}
An abstract of the thesis of Craig O. Smith for the Master of Arts in German presented August 2, 1996.

Title: Dramatic Conflict and Historical Reality in Carl Zuckmayer's Hauptmann von Köpenick

Carl Zuckmayer drafted his drama, Der Hauptmann von Köpenick, as an intended contribution to the Heidelberger Festspiele in late 1930. He chose Wilhelm Voigt's 1906 seizure of the Rathaus in Köpenick as the theme best suited for the realization of his twofold intention - the combination of an Eulenspiegel figure and criticism of contemporary events. The following thesis analyzes the relationship between theatrical and historic event through an examination of the composition of the Hauptmann von Köpenick's generic elements. Through an evaluation of Zuckmayer's drama in terms of form, technical composition, and socio-political environment, this study intends to arrive at a complete understanding of the thematic construction of the play's central dramatic conflict.

The central conflict of the Hauptmann von Köpenick is analyzed in terms of its relation to history and society. This study evaluates the Hauptmann von Köpenick in terms of structure and genre. It presents the composition of the drama's plot as fully symmetrical, then considers the way in which the varying composition of each act brings that symmetry about. This study examines the significance of the play's structural numerical relationships and their connection to fairy tale. An examination of the drama's fairy tale elements and their impact on the drama's central conflict
\end{abstract}


follows. The Volksstück acts as the ideal genre for a consolidated attack against National Socialism. The genres of Expressionism and Neue Sachlichkeit bring Voigt's subjective struggle for identity against the objective powers of military bureaucracy to full contrast. The dramatic conflict of the Hauptmann von Köpenick is examined next in terms of its relevance to contemporary events, an aspect that brings Zuckmayer's drama into consideration as Zeitstück. The analysis of the Hauptmann von Köpenick concludes that Zuckmayer, by drawing upon the widest possible range of elements, formulated his dramatic conflict into an objective attack against subjective conceptions of struggle supported by the NSDAP. 


\section{DRAMATIC CONFLICT AND HISTORICAL REALITY \\ IN CARL ZUCKMAYER'S \\ HAUPTMANN VON KÖPENICK}

by

CRAIG O. SMITH

A thesis submitted in partial fulfillment of the requirements for the degree of

\section{MASTER OF ARTS}

in

GERMAN

Portland State University

1996 


\section{ACKNOWLEDGMENTS}

To Pr. Dr. Steven Fuller, whose perusals, analyses and tips aided in the transformation of a practically illegible series of disjointed ideas into the virtually decipherable textual interpretation of the following pages. And to my wife, Katja, and my Mother and Father, without whose help this task would have been unaccomplishable. 


\section{TABLE OF CONTENTS}

PAGE

ACKNOWLEDGMENTS $\ldots \ldots \ldots \ldots \ldots \ldots \ldots \ldots \ldots \ldots \ldots \ldots \ldots \ldots \ldots$ ii

Chapter

1. INTRODUCTION $\ldots \ldots \ldots \ldots \ldots \ldots \ldots \ldots \ldots \ldots \ldots \ldots \ldots \ldots \ldots$

2. EVENTS OF THE PLOT $\ldots \ldots \ldots \ldots \ldots \ldots \ldots \ldots \ldots \ldots$

3. HISTORISCHE UND SOZIALE DICHTUNG $\ldots \ldots \ldots \ldots \ldots \ldots \ldots$

4. STRUCTURE OF THE PLOT $\ldots \ldots \ldots \ldots \ldots \ldots \ldots \ldots \ldots \ldots \ldots$

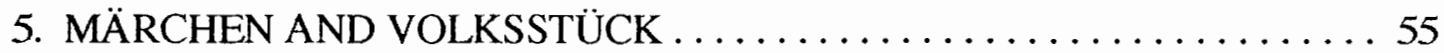

6. EXPRESSIONISMUS KONTRA

NEUE SACHLICHKEIT $\ldots \ldots \ldots \ldots \ldots \ldots \ldots \ldots \ldots, 76$

7. ZEITSTÜCK IM MÄRCHEN $\ldots \ldots \ldots \ldots \ldots \ldots \ldots \ldots \ldots \ldots$

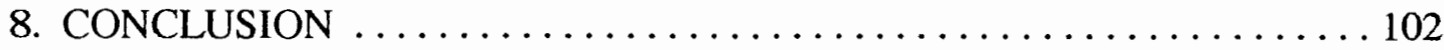

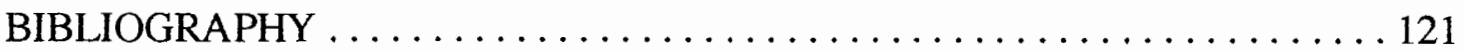




\section{INTRODUCTION}

The breadth of popularity that Carl Zuckmayer's Hauptmann von Köpenick was able to claim makes it stand out not as a monument to, but against the times. At the time of its premiere on March 5, 1931 at the National Theater in Berlin, battle lines of civil unrest had already been drawn. The Weimar Republic was torn by internal divisions from top to bottom. Hermann Müller's resignation from the post of Chancellor on March 27, 1931 "marked the end of the German democracy in Weimar." 1 The Center Party supported a program of "sensible" authoritarianism with provisions for rule by emergency decree under Article 48 of the constitution if the Reichstag could not resolve its internal divisions. ${ }^{2}$ Since 1928 , "the old schemes for staging a coup d'état and setting up a directorate had been surreptitiously circulating in various quarters of the Reichswehr. In short, everything the Republic had spent so long trying to escape from was back again."3 Following a vote of no confidence on July 18, 1930, Chancellor Brüning informed Parliament that Hindenburg had ordered its dissolution. ${ }^{4}$ The results of the election of September 14, 1930 increased the threat of a revolution from both sides:

The principal gainer was the National Socialist Party with its 6.4 million votes (18.3 per cent), won for the most part in Protestant rural areas. Instead of the little band of twelve members they had hitherto had, 107 uniformed(!) National Socialists filed into the Reichstag as the second strongest party - with the declared aim of abolishing that institution. On the opposite wing, the Communists gained 4.6 million votes and now had seventy-seven seats instead of fifty-four. 5

With the threat from the left by no means ignorable, the predominant menace to the Weimar Republic was mounting with alarming rapidity from the reactionary right. The prevailing tendency was either to step back totally from society and politics, or to cross party lines with the sole intention of doing physical and verbal battle. ${ }^{6}$ 
In contrast to the ideologically polemical style of many of his contemporaries, Zuckmayer's message in Der Hauptmann von Köpenick is clearly peaceful. His remarks in Als wär's ein Stück von mir give every indication of his intention to address contemporary events. In the "Geleitwort" to Ingeborg Engelsing-Malek's »Amor Fati in Zuckmayers Dramen, Zuckmayer emphasizes the same intention with respect to his complete works:

Solche Art von Dichtung, die, ohne im ideologischen Sinn Partei zu ergreifen, dennoch in ihrer Gegenwart wurzelt und sich bemüht, zeitklärend zu wirken, ist wohl schwer 'einzuordnen'. Aus der Tradition ins Künftige wachsend, ohne Richtung oder Eingruppierung innerhalb der eignen Epoche, darin liegt sicher beides, eine Schwäche aber auch eine Stärke. Hier sehe ich auch den Grund, weshalb trotz vielfacher Versuche und Bemühungen bisher darüber keine zusammenfassende Darstellung, keine literaturkritische Diskussion entstanden ist. Es läßt sich da bislang keine Formel finden, keine These, die zur Antithese und Synthese herausfordert, höchstens Eigenschaften, Züge, vielleicht ein Grundzug. ${ }^{7}$

Zuckmayer refused to adapt his work to any particular doctrine in addressing the reality of the times. His method clearly indicates an attempt to compose his work within the Zeitstück genre, free of the outward bias of the Lehr- or Tendenzstück. Many critics place his drama within the Neue Sachlichkeit movement for precisely this reason. Its open criticism of Prussian militarism makes the Hauptmann von Köpenick's call to lay down arms in pursuit of a peaceful solution plainly evident. Zuckmayer's elaborate dramatic composition of the events surrounding Wilhelm Voigt's seizure of the Köpenicker Rathaus in 1906 successfully crosses class and party barriers with its message of peace.

In the Hauptmann von Köpenick, Zuckmayer formulates his dramatic criticism of Prussian militarism into an harmoniously unified whole. He creates of the historical Voigt a figure of guiltless determination in his struggle against bureaucratic and societal forces united against him. Zuckmayer's plot reflects the same unity with 
respect to both the overall dramatic composition and its subdivision into twenty-one scenes. The first and third acts contrast in terms of structural simplicity with the structurally complex second act. The result ia a symmetrically unified whole. The closed construction of the second-act dramatic core reflects itself in each individual scene and character of the Hauptmann von Köpenick. Zuckmayer maximizes the possibilities for the interrelationship between individual dramatic components by providing each with the distinctive traits through which differentiation and comparison become possible. His inclusion of the triple relationship of the Zahlenmystik at various levels forms the principal structural bond between Zuckmayer's "Märchen in drei Akten" and the world of fairy tale. Zuckmayer composes the tripartite division of the Hauptmann von Köpenick into a structurally unified statement of internal harmony.

In transforming the folk-hero, Wilhelm Voigt, into a fabulous character for dramatic presentation, Zuckmayer combines the traditional and timeless elements of fairy tale with the socially critical and entertainment demands of the Volksstück. Voigt corresponds to the third royal son of Wilhelm Grimm's fairy tale interpretation, the subjective spirit of humanity in conflict with the objectifying forces of bureaucracy. Zuckmayer transforms and lends new sense to the sentences he takes from Rumpelstilzchen and the Bremer Stadtmusikanten. Both fairy tale and Volksstück complete the bond between stage, author, and audience. The author performs his societally critical function as author in the Volksstück genre. He transforms sociopolitical reality into a piece of dramatic entertainment fit for public performance. Zuckmayer draws on the principal genres from his era and the Western literary tradition in formulating his attack against the spirit of militarism. Yet the Hauptmann von Köpenick preserves an objective attitude of presentation throughout, never lapsing 
into defamatory language or tendentiousness. The Märchen element provides the timeless quality that permits Zuckmayer to address his anti-military theme to the contemporary events of 1931 . The Voigt Zuckmayer transforms into the fairy tale figure of his Volksstück represents the subective human will at odds with the gathering forces of objective military absolutism.

In the Hauptmann von Köpenick, Zuckmayer takes an objectively critical look at societal indifference to the plight of a man without work and official identity. Through a contrast of similar but distinct objects of the stage, Zuckmayer draws out the subjective-objective distinction that reaches the heighth of contrast in the Expressionistic twelfth scene. To this he opposes an overall construction in the Neue Sachlichkeit genre. Within the Hauptmann von Köpenick, the element of Sachlichkeit reflects the spirit of indifference of the leaders of Weimar to the economic hardships of the lower classes and mounting threat of military authoritarianism.

The timelessness of fable clears the ground for the Hauptmann von Köpenick's assault on the traditional roots of Prussian militarism. By bringing Wilhelmine Germany into direct relationship with Weimar, Zuckmayer exposes the conservative German justice system and military objectives of the NSDAP at their traditional authoritarian core. Joseph Goebbels' open defense of his party's objectives against the Hauptmann von Köpenick's satire of militarism demonstrates the relevance of its author's Zeitkritik. Zuckmayer's drama links the democratic present of 1931 to the looming spectre of its undying authoritarian past.

Zuckmayer unites historical and social criticism at the psychological level at the level where individual confronts society. He bases his drama on the publicly sensational criminal prank of a cobbler become folk hero: 
Am 16. Oktober 1906 verwandelte sich der arbeitslose, mehrfach vorbestrafte Schuster Wilhelm Voigt durch eine bei einem Trödler erstandene alte Uniform in einen preußischen Hauptmann. Er brachte eine Handvoll Soldaten unter sein Kommando, besetzte mit ihnen das Köpenicker Rathaus, verhaftete den Bürgermeister der Stadt Köpenick, ließ sich die Stadtkasse uibergeben und ward nicht mehr gesehen. ${ }^{8}$

Zuckmayer intensifies the effect of Wilhelm Voigt's metamorphosis into the "Captain of Köpenick" by transforming the historical Voigt into a victim of societal circumstance. He strays from factual presentation of the events surrounding October 16, 1906 in order to preserve the spirit of the Köpenickiade as reflected in the German press. The original Voigt was by no means beyond guilt. The fictive Voigt is. Zuckmayer shifts the full motivation for Voigt's coup from the scheming individual onto the military bureaucracy. The authoritarian Prussian military system imposes its psychology over von Schlettow's aristocratic sense of propriety, Obermüller's bourgeois intellectualism and Voigt's lower-class common sense. Schlettow, Obermuiller and Voigt, as psychological victims of authoritarian ideological control, are the characters through whom Zuckmayer exposes the nonsense in the well-ordered authoritarian system.

The broad comedic genre is the vehicle Zuckmayer uses to span class barriers and objectify authoritarian thought for an effective catharsis. Through the method of the Neue Sachlichkeit, Zuckmayer exposes the absurdity of the sort of bureaucratically objective thinking that loses sight of its human subject. Voigt's purely subjective surrender to righteous self-justification enters the domain of the absurd as he, despite meticulous attention to detail, loses sight of the entire object of his Rathaus seizure. Zuckmayer examines the absurdity of a militarily controlled society at all class levels and, through Voigt, from both outside and in. 
Zuckmayer's Hauptmann von Köpenick presents a dramatic conflict that directly confronts the National Socialist conception of struggle in appeal and content. Voigt is a symbol of the part of the German people disinherited by the Depression. By extension, he symbolizes the German people as a whole. Zuckmayer combines the full range of literary techniques at his disposal to contemporize what he sees as the ongoing struggle of the German people for sovereignty against its age-old foe: the stubbornly rigid spirit of Prussian militarism. Zuckmayer brings the central dramatic conflict to the level of psychological confrontation with a repetition of the antagonistic opposition between the interests of the civil individual and military society that spans history and class. The central dramatic conflict of the Hauptmann von Köpenick becomes the people's struggle between exclusion and integration defined in structural terms. In the language of poetry it is the struggle of democracy against the unseen forces of history incorporated in the military bureaucracy. Zuckmayer uses the techniques of Expressionism and the Neue Sachlichkeit in order to raise the subjectiveobjective dischord between the humanitarian ideal and its subversion by bureaucratic order to the level of open confrontation. As a criticism of contemporary developments in the Zeitstück genre, the Hauptmann von Köpenick embodies the battle of the people for autonomy. It describes the people's battle for hegemony against the constricting power of traditional authoritarianism under resurrection by a new order composed largely of military upstarts. Zuckmayer's objectification of societal relationships appeals to the reason of the people. The baldly subjective arguments of the leaders of the NSDAP appealed to public emotion. Voigt's comic struggle for identity is the German people's attempt at maintaining autonomy against the stifling powers of a military bureaucracy. The leader of the NSDAP formulated the struggle of the German people and military against the powers of Parliament into the personally 
subjective language of Mein Kampf. Zuckmayer, on the other hand, appeals to the objective power of reason. Hitler appealed to public emotion. Zuckmayer confronts German society with his own all-encompassing version of struggle that directly opposes the views of the writer of Mein Kampf in both its method of appeal and in its placement of loyalties. 


\section{ENDNOTES}

1 Helmut Heiber, The Weimar Republic, trans. W.E. Yuill (Oxford, U.K. and Cambridge, U.S.A.: Blackwell Publishers, 1993) 170.

${ }^{2}$ Heiber, 171.

3 Heiber, 173.

${ }^{4}$ Heiber, 176.

5 Heiber, 177.

6 Zuckmayer describes the spirit of violence that ruled the streets at the time of his drama's premiere. See below, page 65, note 36 .

7Carl Zuckmayer, "Geleitwort," Ingeborg Engelsing-Malek, "Amor Fati« in Zuckmayers Dramen (Berkeley and Los Angeles: University of California Press, 1960) vii.

${ }^{8}$ Siegfried Mews, Carl Zuckmayer: Der Hauptmann von Köpenick:

Grundlagen und Gedanken zum Verständnis des Dramas (Frankfurt am Main, Berlin, München: Verlag Moritz Diesterweg, 1982) 8. 


\section{EVENTS OF THE PLOT}

The Hauptmann von Köpenick's internal divisions provide for the greatest number of interrelations between character and elements of the plot. Zuckmayer divides the Hauptmann von Köpenick into three acts of seven scenes each. Each act forms a closed unit, as do each of the scenes. Zuckmayer thus lends the acts and scenes of his "deutsches Märchen in drei Akten" the possibility for forming comparative relationships within the text. He provides each member of his cast of seventy-three characters with the distinguishing features necessary for their wide-scale comparison. "Die Figurenkonstellation entspricht dem dramaturgischen Grundprinzip der kontrastiven, additiven oder differenzierenden Verklammerung von Szenen.”' Each scene rounds out with some sort of capping statement, appearing in most cases at the scene's end. The first act is an Expressionistically disconnected series of scenes in the form of a comedic Stationendrama. The second act is a symmetrically constructed Trauerspiel. The scenes of the third act run through the series of logical steps of the "slapstick comedy" of the Köpenickiade. The first and third acts form a comparative bond on the basis of uniformity. The unidirectional motion of the third act, however, forms a unified contrast with the monotone atmosphere of stagnation of the first act. The second act opposes both on the basis of its complexity of dramatic motion and its intricate structural relationships. The internal components of Zuckmayer's drama form wide-ranging interrelationships at all levels.

Adolf Wormser's "Uniformladen" in Potsdam constitutes the setting for the first scene of Zuckmayer's drama. ${ }^{2}$ Wormser is fitting Hauptmann von Schlettow for a new uniform when the latter detects that, "mit der Uniform da stimmt was nicht. Da is was nich in Ordnung. Das hab ich im Gefühl" (7). To Wormser's initial resistance to the idea of making a slight alteration in the distance between the "Gesäßknöppe" in 
compliance with mitlitary regulations, Schlettow mentions to Wormser that one notices "auf Schritt und Tritt, daß Se nich gedient haben." As arrangements are being concluded for the alterations in tailoring, the specter of Wilhelm Voigt appears twice "an der Glastür." Voigt silently departs after his first appearance. But when asked a second time what he wants, Voigt says: "Ick wollte mir nur mal erkundigen -," to which Wormser responds with, "Raus!! Hier wird nich gebettelt!!" (11). The scene closes with Schlettow's statement: "Wenn ich mir eine neue Montur bauen lasse, denn muß nu alles tadellos in Form sein, da hab ich meine Freude dran, verstehense?" (11).

In the second scene, Voigt appears in the bureaucratic sphere represented by the Polizeibüro in Potsdam. He repeats the line of the first scene: "ick wollte mir nur mal erkundigen - "(12), this time about a residence permit. The "Oberwachtmeister" recites Voigt's official history in examining his file: "Fuffzehn Jahre Zuchthaus, wegen Posturkundenfälschung" (13). Voigt describes his subsequent employment by a Jewish shoe manufacturer in Bucharest and the reasons for his return to Germany:

Da unten, da sinse alle janz anders, und da redense ooch janz anders. Und da hat nu schließlich der Mensch seine Muttersprache, und wenn er nischt hat, denn hat er die immer noch. Det glaubense jarnich, wie scheen Deutschland is, wenn man weit wech is und immer nur dran denkt. Aber ick sage ja, det war dumm von mir (15).

Zuckmayer places the Pointe of the second scene within a few verbal interchanges before the conclusion, as indicated by the Oberwachtmeister's command, "Jetzt machense mal 'n Punkt" (17). Voigt's answer cuts to the central Heimat theme that forms a main ingredient in the structuring of the core of Zuckmayer's drama: ${ }^{3}$ "Nee, nee ick reg mir jarnich uff, aber't muß ja nu 'n Platz geben, wo der Mensch hingehört!" (17). The scene concludes with a bureaucratically abrupt command for Voigt to leave. Voigt has interrupted the Oberwachtmeister and Wachtmeister during their lunch-break with his awkward inquiries. 
The publicly diverse intercultural realm of the Café National in Berlin forms the setting for the third scene. Zuckmayer elevates the scene to the status of fable through his integration of a self-fulfilling prophecy paralleling Aesop's "slow and steady wins the race." The grenadier coaxes the Plörösenmietze to his table. Tensions rise as Kalle objects. Schlettow ignores protocol to check the grenadier's militarily inappropriate behavior. A comic scene results in which the rankingly superior Schlettow scuffles with the grenadier, who rejects Schlettow's call to obedience with an insult: "Det kann jeder sagen! For mir biste'n deemlicher Zivilist!" (29).

The fourth scene takes place in the public sphere of the "Axolotl" shoe factory's personnel office, where Voigt inquires after a job. This is the only scene for which the stage instructions give no details regarding location in the Berlin area. The clerk asks Voigt, "Wo hamse gedient?" He turns Voigt away in repetition of the same theme of exclusion of the first and second scenes. The clerk repeats his "Wo hamse gedient??" to the next comer as the lights go down (32-33).

The private sphere of Schlettow's elegantly furnished room in Potsdam sets the atmosphere for the fifth scene. Wabschke appears with his tailored uniform. Schlettow announces his military resignation to Wabschke. Wabschke consoles Schlettow with the consideration, that "wenn eener 'n richtiger Mensch is, det is doch de Hauptsache, nich?" Schlettow soliloquizes over these words: "Vielleicht vielleicht hat er recht - Nee, pfui!" (36).

The public "Herberge zur Heimat" in north Berlin forms the setting for the following scene. Its setting is really a cross between the private and public sheres. A representative body of the male unemployed from all over Germany constitutes the cast. Voigt reveals his plan for erasing his criminal record by breaking into the Polizeirevier in Potsdam (40-41). A Wachtpatrouille appears to enforce curfew, check 
passes and impose silence. The lights of the sixth scene are extinguished as Voigt states to the nearly sleeping Kalle, "Herrgott - wenn ick erst raus bin -" (47).

The seventh scene returns the action to the setting of scene number one. Dr. Obermüller comes to order a uniform as an officer of the reserve (49). Wormser convinces Obermuller to accept the alterations in Schlettow's former uniform. He remarks, as Obermüller gets out of ear shot: "Der hat's geschafft. Was heutzutag nich alles Offizier wird! Nemm dir e Beispiel, Willy!" (52). The first act thus establishes Voigt's exclusion from society and ends with an indirect solution to his problem as exemplified in the person of Obermuiller.

The second act commences with the eighth scene. The Zuchthauskapelle of the Prussian corrections facility of Sonnenburg provides the setting. A celebration of the fortieth anniversary of the victory of Prussian troops over French forces is held "Sedantag" (Zuckmayer has added four years to the original date of Voigt's Köpenickiade, so the year is now 1910). ${ }^{3}$ In a mock-up reenactment of the battle, Voigt tests his abilities in the role of commander and excels. The scene concludes with the prison director's praise of Voigt's talent for marshaling troops:

Hervorragend. Voigt! Beisspielgebend! Zu den andern Das ist ja diejenige denkende Selbständigkeit des Unterführers, die im Ernstfall benötigt wird. Ein Jammer, daß es zu spät ist. Voigt! Sie sind der geborene Soldat, trotz Ihrer O-beine. Aber jetzt setzt sich die Kavallerie in Galopp und geht zur Attacke uiber! Vorwärts marsch! (58).

The living room of Voigt's sister and her husband in Rixdorf forms the private atmosphere of the next scene. Frau Hoprecht receives her brother and offers him shelter (63). Her husband is a soldier in the reserves (63). Hoprecht returns from work, welcomes Voigt and sustains his hopes for fair treatment by the authorities:

Das geht alles seinen Gang, Willem. Machen kannste da gar nichts. So wolln wir jetzt auch gar nicht anfangen, was? Da mußte den 
richtigen Weg einschlagen, denn klappt das auch. Hintenrum, das wär ein Delikt! Und was dir zusteht, das kriegste, dafür sind wir in Preußen. Also prost, Willem, aufs neue Leben! Da mach dir man keine Sorgen. Das geht alles seinen Gang!

The ninth scene closes as Voigt clinks glasses with Hoprecht: "Na, prosit!" (65).

The tenth scene takes place in the private bedroom of Obermuiller and his wife in Köpenick. Obermüller needs his new uniform for the "Kaiserliche Manöver," but the new uniform must be expedited by telephone from Wormser's (66). The former uniform of Schlettow has grown too small to fit Obermüller's present proportions (67). Wabschke arrives with the uniform's replacement. Taking the used uniform with him in departing, Wabschke states as the lights go down: "Na, fiern Maskenball wird se vielleicht noch jehn." (69).

The setting of the eleventh scene is provided by the foyer of the Einwohnermeldeamt of the Polizeirevier in Rixdorf. Voigt waits for entry to room number nine, where he has been instructed, "probiernse's mal drin" (71). The officer of the police responds to Voigt's pleas that his case must be heard, “- denn is ja zu spät" (71), with the repeated command for Voigt to take a seat. The police officer disappears into his office. The reader of the Social-Democratic Vorwärts announces that time has run out, and leaves (73). Voigt remains on his own. The voice of the officer can be heard with increasing volume from inside his office: “... kann ich keine Rücksicht nehmen! Befehl is Befehl, darnach habense sich zu richten!!" Voigt then rises from his seat, tiptoes to the office door and peeps through the keyhole as the lights go out (73).

The highly private realm of the garret at the Hoprechts' in Rixdorf lends an atmosphere of seclusion to the twelfth scene. Voigt comforts the ailing Liesken. Court musicians sing their songs outside. Liesken evidences her slipping health by 
begging Voigt not to leave her. While reading her a passage from the Bremer Stadtmusikanten of the Brothers Grimm, Voigt receives the order of expulsion from a bureaucratic representative. He reads the notice sotto voce, believing that Liesken has fallen asleep. He stops reading, and she prompts him to continue. As the lights fade, he resumes his reading of the fairy tale lines: "Komm mit sagte der Hahn - etwas besseres als den Tod werden wir überall finden" (78).

The following scene takes place in the Festsaal bei Dressel. A celebration takes place, in which the Wormsers and various representatives of the military caste take part. The thirteenth scene ends with an appearance by Wormser's daughter, Augusta, dressed in the uniform previously owned by Schlettow and Obermuiller. The uniform accidently gets spotted with pineapple compote, champagne and water from a vase as Wormser reaches over the table to light the master of cavalry's cigarette. In response to Augusta's laugh, Wormser states: "lach nicht auch noch! Die schöne Uniform! Jetzt kannse zum Trödler." Augusta answers irreverently: "Da gehört se auch hin!" (84).

The fourteenth scene returns the action to the private sphere of the Hoprecht's livingroom in Rixdorf. Frau Hoprecht tells her husband of Liesken's death and Voigt's attendance at her funeral (85). Voigt returns and declares his departure in accordance with the official expulsion order (88). He remains oblivious to Hoprecht's assertions that, "Bei uns gibt's kein Unrecht! Wenigstens nich von oben runter! Bei uns geht Recht und Ordnung uiber alles, das weiß jeder Deutsche!" (90). Voigt departs with the laughing exclamation that, "Was de andern können, dat kann ick noch lange." The scene lighting fades with Hoprecht's remark: "Der Mensch - der Mensch is ja gefährlich!!" (92). The second act thus concludes with evidence that Voigt has decided on doing something drastic toward the improvement of his condition. 
The fifteenth scene commences the final act as Voigt appears in the public realm of "Krakauers Kleiderladen." Voigt buys Schlettow's original uniform under pretense: "Ick brauchse fiern Maskenball" (93). Krakauer sends him on his way: “Adjeh, Herr Hauptmann, viel Vergnïgen, Herr Hauptmann!! - Auch e Hauptmann!!” (96).

The public realm of the Sanssoucci Park in Potsdam provides the setting for the isolated mini-drama of the sixteenth scene. Apart from Voigt's presence as observer upon the scene, its action is external to the developments of the main plot (thus serving as a neu-sachlich counterpart to the internally motivating events of the twelfth scene). Different pairs of uniformed members of society establish an external referent to the internal plot of the Hauptmann von Köpenick. Voigt's courteous comportment in comparison with the malicious behavior of a pair of young boys gains recognition in the remark of one of a pair of elderly women: "Bei jungen Leuten findet man heutzutage leider solche Höflichkeit nicht mehr." To which her companion wisely answers, "Ja, ja, die alte Schule" (99).

The action of the seventeenth scene transpires in the public realm of the Schlesischer Bahnhof, in Berlin. Voigt, carrying a cardboard box, walks past a pair of railway officials, enters the public lavatory and emerges in military Captain's attire. He commands one of the pair to consign his package to the Gepäckaufbewahrung. He then dismisses them from duty, to which the first official responds with "Jawohl, Herr Hauptmann" (102).

The foyer of the Rathaus in Köpenick, the bureaucratic sphere, is the setting upon which the action of the eighteenth scene intrudes. After a pro forma exchange between various officials, the sound of bootsteps and military commands enters the set from beyond the scenes. Wearing the Hauptmannsuniform, Voigt enters in command 
of a ten-man force and rapidly takes affairs under his own authority (105). He announces an order from above calling for the imposition of Belagerungszustand to the Stadtschutzmann Kilian, to whom he immediately delegates the responsibility of giving the command to "marsch" (106).

The action of the preceding scene carries directly over into the guardedly private bureaucratic realm of Obermüller's gubernatorial office in Köpenick. Voigt takes everyone and everything into military custody with reference to a command issued from his superiors (107). His establishment of authority is primarily based upon his use of the previously ingrained rhetorical device, "Haben Sie gedient?" (107-108). Upon experiencing that passports are not issued in Köpenick (110), Voigt maintains his composure and orders his troops to confiscate the till's contents, which he takes into personal custody before abandoning the set of the nineteenth scene (116).

The twentieth scene transpires in the open public setting of "Aschingers Bierquelle in der Neuen Friedrichstraße." As the charwoman prepares to clean up before opening time, she discovers Voigt sleeping on a bench (116). The waiter explains that Voigt fell asleep in his dinner the evening before (117). A group of guests enters, and the chauffeur laughingly announces the news of events in Köpenick (118). Holding a copy of the "Extrablatt," the driver reads the description of the "Hauptmann von Köpenick" aloud: "Mager und knochig - jebeugte Kopfhaltung schiefe Schulter - bleiches häßliches Jesichte - krankhaftes Aussehen ..."(11920). Voigt listens silently as the lights go down.

The twenty-first scene takes place in the bureaucratic realm, in the interrogation room of the "Berliner Polizeipräsidium." The inspector reads the report of the Kaiser's reaction to the Köpenickiade: "Habense den Geheimbericht nich gelesen? Gelacht hat er, wie man's ihm vorgetragen hat, und stolz war er noch drauf! 
Mein lieber Jago, hat er zum Präsidenten gesagt, da kann man sehen, was Disziplin heißt! Kein Volk der Erde macht uns das nach!" (121). The inspector comments that forty arrests have been made and dozens of confessions given. The Passkommissar announces Voigt as the "Hauptmann von Köpenick" (122). He explains the declaration Voigt has made before him in the passport issuing office: "Er sei der vorbestrafte Wilhelm Voigt und brauche unbedingt einen Paß. Wenn ich ihm verspreche, daß er später einen $\mathrm{Pa}$ ß bekommt - er sagte ausdrücklich 'später' - , dann könne er mir den Hauptmann von Köpenick zur Stelle schaffen." (122). He adds that he complied with Voigt's request by making the promise, upon which Voigt revealed himself as the culprit (122-23). The uniform is also recovered. His captors treat Voigt with respect and hospitality, offering him a glass of port and something to smoke. "So gut is mir noch nich jegangen uffn Amt," says Voigt. "Sonst hamse mir immer nur einjesperrt oder rausjeschmissen" (127). Voigt asks for a mirror, that he might view himself for the first time in captain's uniform. Standing with his back to the audience, silent then with twitching shoulders, he begins to tremble and stagger to the point that wine spills from his glass (128). Voigt turns toward the audience and begins laughing with growing intensity, "mit dem ganzen Körper, aus dem ganzen Wesen - lacht, bis ihm der Atem wegbleibt und die Tränen herunterlaufen." A word forms itself out of his laughter, "erst leise, unverständlich fast - dann immer stärker, deutlicher, endgültiger - schließlich in neuem, großem, befreitem und mächtigem Gelächter alles zusammenfassend Unmöglich!! Dunkel" (128).

Zuckmayer combines modern and traditional elements in laying out the structure for the Hauptmann von Köpenick. The "Stationendrama" of the first act forms the underlying theme for Voigt's second-act decision to carry out the Köpenickiade of the final act. Despite Zuckmayer's deft use of the techniques of 
Expressionism and the Neue Schlichkeit, the overall dramatical structure is very traditional. The peripeteia comes at the middle of the play (following the twelfth scene). The plot then follows the falling pattern of the traditional katabasis up to the closing scene. ${ }^{4}$ The general structure of the Hauptmann von Köpenick is fairly traditional, but Voigt's direction of his final exclamation to the audience leaves the plot open-ended. In this respect, the close of the final act directly contradicts Aristotelian dramatic convention. ${ }^{5}$ 


\section{ENDNOTES}

1 Jürgen Hein, "Zuckmayer, Der Hauptmann von Köpenick," Die Deutsche Komödie vom Mittelalter bis zur Gegenwart, ed. Walther Hinck (Düsseldorf: August Bagel Verlag, 1977) 278.

${ }^{2}$ Hein presents a threefold breakdown of the realms of activity presented in the scenes the Hauptmann von Köpenick. His scheme is adhered to here for the simplistic clarity that it offers for differentiation between scenes. Hein defines his categorization of scenes as follows: "Die neunzehn verschiedenen Bühnenorte lassen sich in drei Gruppen einteilen, in private (Möbliertes Zimmer, bürgerliche Wohnstube, Schlafzimmer, Stube mit Bett), öffentliche (Uniformladen, Café National, Personalbüro, Herberge, Allee, Bahnhof u. a.) und amtlich-polizeiliche (Polizeibüro, Zuchthauskapelle, Amtszimmer des Bürgermeisters u. a.)." Hein, 278.

${ }^{3}$ The Sedantag was an outward manifestation of the German heroising trend that extends back into the nineteenth century with Germany's 1813 victory over Napoleon at the "Battle of the Peoples" at Leipzig. "Militarism, heroism, and national unity were also the keynotes of the newly-instituted national feast day to celebrate the victory over the French at the battle of Sedan in 1870." Ian Kershaw, The Hitler Myth: Image and Reality in the Third Reich (Oxford: Clarendon Press, 1987) 14.

${ }^{4}$ Gero von Wilpert defines "Peripetie" in the following terms: "seit Aristoteles (Poetik Kap. 10 und 11) Begriff der Poetik, insbes. des Dramas für den (oft im Mittelakt liegenden) Höhepunkt des inneren Aufbaus, auf den die Handlung hinstrebt, der e. wegen der Spannung überraschende, jedoch nicht zufällig erscheinende Schürzung des Knotens - oft durch Anagnorisis - enthält und nach dem Umschlag selbt in die fallende Handlung (Katabasis) übergeht." Wilpert, Sachwörterbuch der Literatur (Stuttgart: Alfred Kröner Verlag, 1964) 505.

5In the Poetics (1449b), Aristotle's designation of tragedy as "Nachahmung einer ... in sich geschlossener Handlung" has had a strong impact on traditional dramatic theory in general, especially since the second book of his Poetics has been lost. Aristoteles, Poetik: Griechisch/Deutsch, trans. and ed. Manfred Fuhrmann (Stuttgart: Philipp Reclam jun. GmbH, 1982) 18-19. 


\section{HISTORISCHE UND SOZIALE DICHTUNG}

The historical dimension of Der Hauptmann von Köpenick is undeniable, and many see it as the definitive element of its content. Yet Zuckmayer's portrayal of the social environment of the Wilhelmine era does not meet with universal acceptance by any means. His drama nearly always receives condemnation from Marxist critics for his failure to investigate the underlying capitalistic determination of the events of the Köpenickiade. ${ }^{1}$ The Hauptmann von Köpenick is, however, a masterpiece of synthesis of the genres of historical and social drama. By focusing his attention on the military theme, Zuckmayer offers a compelling picture of the military presence that pervaded Wilhelmine society down to the individual mentality of the citizenry. ${ }^{2}$ Behind the fabulous theme announced by Zuckmayer's deutsches Märchen in drei Akten, its relevance to historical fact makes itself unfailingly clear:

Doch bricht das Geschehen um den historischen Hauptmann von Köpenick, seine Authentizität und komische Widerspiegelung im Stuick, die Märchenwirklichkeit auf. Das Spiel um des Kaisers Kleid, die Uniform, weist hinaus auf die historische Wirklichkeit der Wilhelminischen Ära, der es entspringt. ${ }^{3}$

In order to heighten that "authenticity" and more comically reflect the spirit of Germany under constitutional monarchy, Zuckmayer transforms the personality of the historical Gauner around whom he bases his plot. He cleanses Voigt nearly totally of culpability for the punishment he receives from society and bureaucracy, thus largely reflecting journalistic reception of the historical mini-coup of October 16, 1906. The actual Voigt was nonetheless a victim of circumstance. Zuckmayer reverses the element of motivation for Voigt's crime, however. By making the military bureaucracy the culprit behind Voigt's motivation, Zuckmayer is able to present a far broader picture of the bureaucratic apparatus in the social context. He moves Prussian militarism and bureaucracy into position for direct conflict with Voigt, enabling his 
drama to demonstrate the underlying danger to German internal constitutional security posed by the expanding might of the military on the eve of the First World War. He describes the point at which the military comes into immediate contact with the individual at all levels of society, from aristocracy to bourgeoisie to working class. Zuckmayer exposes the trend of societo-militarily induced self-abnegation at all levels, each time showing the underlying irrationality in individual conformity to military principles.

Although remaining close to the skeleton of events around which his plot evolves, Zuckmayer liberally employs poetic licence in altering about every essential detail in the character of Voigt and the circumstances surrounding the Köpenickiade. "Die Vorgeschichte Voigts wird gänzlich umstrukturiert und anders akzentuiert."4 The same holds true for particular details of Voigt's character, of the manner with which he seizes the Rathaus and of succeeding events. Zuckmayer transfers the motivating impulse for the historical Voigt's action from the figure himself to the malevolence of military bureaucratic forces that implicitly receive the bulk of the blame.

In shifting the guilt from the historical Wilhelm Voigt to the bureaucratic milieu against which he launches his coup, Zuckmayer is fully in keeping with the event's original public reception as immediately manifest in most of the press. The left was jubilant. The bourgeois center criticized the power of the military, while the conservative right stood behind it and shifted the blame to the unmilitary conduct of the officials at Köpenick. ${ }^{5}$ With the anaphoral repetion of the words, "Die Welt lacht," the Social Democratic Vorwärts of 18 October 1906 seized upon the events at Köpenick as an opportunity to mock its aristocratic enemy from an international perspective. ${ }^{6}$ The more moderate Vossische Zeitung received Voigt's action as a 
warning against similar occurences because of the priveleged aspect the uniform lent anyone, regardless of character. ${ }^{7}$ In an article entitled "Fetischuniform," the Berliner Tageblatt criticized the way in which all political sectors prostrated themselves to anyone wearing the Prussian uniform, merely "weil er uniformiert ist." 8 To suit the political environment of 1931 , Zuckmayer seizes upon the same critical feeling that had surrounded the uniform in 1906 and concentrates his attack.

The elimination of the guilt-aspect pertaining to Voigt is fundamental to Zuckmayer's redefinition of the circumstances surrounding his leading character's decision to take justice into his own hands. He thus exaggerates the severity of Voigt's original conviction, thereby instilling his protagonist with sufficient righteous indignation to justify his ultimate breach with the law.

Der historische Voigt wird erst als Zweiundvierzigjähriger nach einer Serie von Vorstrafen wegen Diebstahls im Rückfall zu fünfzehn Jahren Zuchthaus verurteilt, Zuckmayers Voigt schon als 'junger Dachs' und beim ersten lächerlich geringfügigen Delikt, so daß es scheinen muß, daß Voigt ein Opfer des brutalen Polizei- und Justizterrors ist. ${ }^{9}$

Zuckmayer in fact reinterprets the character of Voigt to such a degree, that the fictional Voigt really does become an inadvertant victim of a sort of unconsciously directed "brutal police and legal terror." Zuckmayer deletes all traits from the fictional Voigt's character that could create a bias against him. ${ }^{10}$ And while the Voigt of Zuckmayer's drama strives for nothing more than a societally justified position, the historical Voigt was constantly searching for a new and better home along with improved military placement:

Das Wanderpensum des realen Voigt ist enorm. Der Teufelskreis des fiktiven Voigt, ohne Arbeit keine Papiere und ohne Papiere keine Arbeit zu erhalten, hat sich um die historische Figur nicht in diesem fatalen Sinne geschlossen. Voigt hat 1906 in Wisnar eine Arbeitsstelle gefunden, zieht ohne Not weiter nach Berlin, findet auch dort Arbeit und wird erst hier ausgewiesen. ${ }^{11}$ 
The Voigt who committed the sensational robbery of 1906 strove for material aggrandizement and had learned "von Kindsbeinen an den Glanz der Ordnung als höhere Wirklichkeit zu verehren." 12 The "higher reality" of his fictive counterpart is the human dignity that he asserts against the bureaucratic forces of order. His humble desire for societal integration at the level of common citizen stands in marked contrast to the aspirations of the historical Voigt, who seems to have been obsessed with no greater notion than to raise himself above the common crowd. The fictive Voigt yearns to join society. When refused a residence permit for being unemployed, Voigt states to the Oberwachtmeister, "Nee, nee ick reg mir jarnich uff, aber't muß ja nu'n Platz geben, wo der Mensch hingehört!" (17). The actual Voigt was fully willing to divorce himself from society. There was no discrepancy between the actual Voigt's character and his criminal act. Zuckmayer purges all trace of guilt from the original Voigt in transforming him into the fabulous protagonist of the Hauptmann von Köpenick. The pureness of the fictitious Voigt's character stands in marked contrast to the criminality of his Gaunerstreich and constitutes one of the principal ingredients in the dramatic tension of the plot.

Yet as reflected in the popular press of 1906 , the element of guiltlessness was not wholly absent from the character of the historical Voigt. The Berliner Morgenpost thus commented: "Die Traurigkeit, die in Voigts Schicksal liegt, ist nicht ganz vom Fatum, sondern zum guten Teile von der Unzulänglichkeit der von uns selbst gesetzten Institutionen verursacht." 13 Zuckmayer applies the talents of his craft to shift the majority of the guilt from the character of Voigt to the institutions he skillfully represents as institutions of blind repression.

Zuckmayer reverses the impetus and intentions of the factual Voigt in transferring them to his counterpart in fiction. The fictional Voigt breaks the law with 
the sole intention of rectifying a personal case of bureaucratic injustice and nothing more. Both his military training and the realization that "Kleider machen Leute" are either forced upon him or come directly from the milieu in which fortune places him. In the fourth scene of Zuckmayer's drama, Voigt experiences the importance society places on prior military service. The hiring clerk, Knell, flatly refuses Voigt's inquiry into employment on the basis of his lack of military service (32). The attitude has already been established in General von Schlettow's remark of the first scene: "Sehnse, Wabschke, bei Ihnen merkt man auf Schritt und Tritt, daß Se nich gedient haben" (8). All of the fictive Voigt's military experience comes from first-hand subjection to the military's universal influence upon society. The account of the reallife Voigt boasts of something approaching an historical mission:

Ich erinnere mich an den Großen Kurfürsten, der auch den Bürgermeister von Königsberg in der Nacht von seinen Trabanten aufheben und nach Brandenberg schaffen ließ, wo er, wenn ich nicht irre, 28 Jahre in der Gefangenschaft verbringen mußte. Auch an die Geschichte des Michael Kohlhaas dachte ich, der vielleicht den bekanntesten Typ des Rechtsbrechers aus gekränktem Gerechtigkeitsgefühl darstellt. ${ }^{14}$

The real Voigt was an autodidact who drew his military knowledge and ideas of revolt from the books of his choice. ${ }^{15}$ His motivation thus came internally and was linked to historico-literary visions of glory. Zuckmayer's Voigt is driven by circumstances from without; his demands are humble and contrast drastically in magnitude with the course of action he takes toward their fulfillment.

The danger to public security represented in the actual Voigt's coup of 1906 was even acknowledged by the aristocratic press. The Königlich privilegierte Berlinische Zeitung feared that the event could be repeated by members of the criminal underworld. Voigt's coup demonstrated "wie gefährlich die gesetzlich angeordnete Ohnmacht der Polizei und des Publikums gegenüber dem Träger der 
Uniform für die öffentliche Sicherheit und Ordnung ist." Since: "In der Tat, des Königs Rock, oder vielmehr der Offiziersrock, ist eine rechtliche, vom Gesetz privilegierte Einrichtung, ganz unabhängig von der Person, die in dem Rocke steckt." 16 As events soon proved, the aristocracy had every cause for concern, since by arming the populace for "The Great War" in 1914, it extended its symbol of authority to a new body that could march home and exercise its authority in execution of its own command for revolutionary overthrow.

By making its presence ubiquitous throughout his drama, Zuckmayer demonstrates the deep social impact the military had on German society as well as history. The mass production shoe factory of the fourth scene is the only setting Zuckmayer provides without detail regarding location around Berlin. The factory could be anywhere in the Weimar Republic, thus symbolically indicating the ubiquity of capitalist forces as partner to the pervasive hold of the military on German society. The eternal return of the uniform into society under different owners in the Hauptmann von Köpenick is symbolic of the military's unyielding historical influence on German politics. The uniform passes first from Schlettow to Obermuiller, then from Obermuiller to Voigt after serving as a costume for Wormser's daughter at a coctail party. When instructed by the Oberwachtmeister that he may obtain a residence permit once he has found employment, Voigt replies: "Ick bekom keene Arbeet ohne de Anmeldung. Ick muß ja nu erst mal de Aufenthaltserlaubnis -" (16). The Teufelskreis in which Voigt becomes trapped reflects the historical divide separating the military and civilian spheres ever since 1848 . German politicians failed repeatedly to impose an attitude of culpability upon the military subsequent to its participation in the revolutions of 1848 and 1918. ${ }^{17}$ Zuckmayer's drama demonstrates the military presence in Wilhelmine Germany not only on the historical and social 
levels. Through the behavior and speech of his characters, he demonstrates the societally dominant military attitude ingrained into the mentality of its people as well.

In the Hauptmann von Köpenick, Zuckmayer levels his wit against the steady tension of the authoritarian power structure's hold on society by concentrating on the single constituent elements of both at the immediate level - at the level where symbol of authority and societal individual come into direct contact. The spirit of authoritarianism eats deeper into its subjects than first appearances would reveal - a fact that Zuckmayer deftly shows through the behavior of his characters. Zuckmayer presents his social evidence with complete objectivity to his audience, thus placing it in the role of scientific observer. Since the spirit of authoritarianism founds itself upon the subjection of the true self to a higher Ordnung, the Mensch behind the public persona is often concealed beyond recognition but for brief moments, when the authoritarian personality drops its guard, and the captive Mensch emerges.

Von Schlettow's acceptance of his own failed career based on strict adherence to rules of formality represents an elevation of the military way of thinking to the level of idealism. The role played by Von Schlettow is, by means of historical analogy, that of the polically empowered aristocracy under the Second Reich. The outward appearance of that body's sovereignty is continually undergoing readjustment as new parties enter the German parliament of the late nineteenth century. In Zuckmayer's drama, the uniform represents that outward appearance, to which Wormser must make adjustments according to Von Schlettow's exacting demands (10-11). Von Schlettow's confrontation with a soldier of lower rank in the Café National shares outstanding parallels with the events of the First World War (and those thereafter). The derivation of the name of the cafe is recognizably French. Von Schlettow comes into conflict with the lower-ranking soldier as a result of an argument over the 
"Plörösenmieze," for whom Zuckmayer chose a name from both French (pleureuse, or "whining") and German "Mietze," meaning "pussycat." The altercation in the Café National represents the engagement of German troops in France during World War I, toward the end of which the ordinary soldiery seized authority through the formation of Soldatenräte still clad in the uniforms of the Prussian military. 18 Von Schlettow represents the powers of aristocracy that relinquished their military hold on society as Germany entered into armed competition with its more democratic neighbors.

A more profound dramatic exploration of Schlettow's authoritarian personality would certainly have been possible had Zuckmayer brought his drama's action closer behind the scenes. "Hätte Zuckmayer ihm mehr Raum gelassen, hätte eine psychopathologische Fallstudie entstehen können, eine Psychopathologie des autoritären Charakters, der auch im Untergang noch die Ursache seines Untergangs rechtfertigt." 19 But what does emerge from Zuckmayer's work is a psychological case study of the effects of the authoritarian system treated from the social perspective. A Schutzmann arrests Schlettow for attempting to enforce military discipline out of uniform in the third scene (30-31). Schlettow announces to his orderly his intention to turn in his resignation (fifth scene). Deltzeit, the orderly, objects that Schiettow has done nothing wrong. Schlettow cuts him short: "Quasselnse nich, Deltzeit. Soviel Pech darf'n Soldat nich haben, das is es. Unglück is auch 'n Versagen." (34). Zuckmayer takes no pains to delve into the private motivating factors of Schlettow. In the purely objective world of military performance (and here Zuckmayer applies the methodology of Neue Sachlichkeit to perfection), failure can ultimately mean either defeat or even death. ${ }^{20}$ Von Schlettow's retirement from the military is not fully tragic, and the luxury of his position prevents him from generalizing on the contradiction between proper military conduct and human happiness. His priorities 
remain falsely placed. Wabschke departs scene five consoling Schlettow that, "wenn eener 'n richtiger Mensch is, det is noch de Hauptsache." Von Schlettow considers the veracity of the inherently democratic principle of human rights for a brief moment: "Vielleicht - vielleicht hat er recht - Nee, pfui!" (36). From the moment of his discharge, Schlettow disappears from the social setting and hence from the stage. In full accordance with the aristocratic ideal of honor, von Schlettow not only causes, but as officer in charge, passes judgment on his own misconduct. He thus symbolizes the aristocracy's surrender of its societally hegemonic position to an ancient institution with which it is no longer fully compatible.

Zuckmayer vividly portrays the rising spirit of opportunism in late Wilhelmine Germany through the character of the Bürgermeister, Dr. Obermuiller. Obermüller utilizes the existing system to climb to a position of elevated social status, from which he readily adopts an elitist attitude. In the seventh scene, Wormser, the owner of the uniform shop, readily feeds on that attitude: "Das Schöne is, daß man was geworden is, was nich jeder werden kann, das macht Spaß" (51). Obermüller's response shows him confidently justified in his position of social superiority: "Umgekehrt, lieber Herr Wormser, grad umgekehrt! Das Große ist bei uns die Idee des Volksheeres, in dem jeder Mann den Platz einnimmt, der ihm in der sozialen Struktur der Volksgemeinschaft zukommt. Freie Bahn dem Tüchtigen! Das ist die deutsche Devise!” (51). Psychological motivation is the underlying ingredient in Obermüller's sophistic reformulation of societal conditions:

Die Intelligenz würde ihren Seelenfrieden nicht finden, wenn sie ihre Anpassung nicht auch intellecktuell rechfertigen könnte. Sie gibt sich liberal und argumentiert idealistisch: 'Das System ist monarchisch - aber wir leben - angewandte Demokratie!' (51) In diesen Verbalen Hochherzigkeiten entlarvt Zuckmayer den Konformismus und die Standpunktlosigkeit des zeitgeschichtlichten 
Liberalismus, dessen Pathos eine Analyse der sozialen Verhältnisse überflüssig machen soll. ${ }^{21}$

Obermuiller is every bit a representative of the rising power of the bourgeoisie in prewar Germany. He is literally symbolic of the expanding dimensions of that body. In the tenth scene, he has outgrown his uniform. His wife, frustrated over the prospect of trying to get him into it, exclaims: "Du bist viel zu dick geworden, du bist viel zu dick, ich sag's ja schon lange" (67). More than half of the officers in the Prussian army came from the nobility in 1865 . By 1913,70 percent were of bourgeois origin. The reserve officers' corps was, however, "almost exclusively drawn from the middle classes." 22 Bürgermeister Obermüller's name indicates him as a striving member of the "Bürger" class attempting to set himself above the other "Muiller" by rising in the reserves. Amongst the military staff, only reserve officers were allowed to take part in politics in pre-war Germany. An instruction book clearly stated, that:
the officer in reserve status must never, while an officer, belong to a party which places itself in opposition to the government of our Emperor or of the Landesherr. If he feels conscientiously restricted by this, then he must request his dismissal. As an officer, he is his imperial master's 'man' in the old German sense of the word. Under no circumstances must he place himself in opposition to him. On the other hand, however, he is fully justified in making use of his political rights and intervening in the political struggle in behalf of the objectives which the government of the Landesherr and the Emperor pursue. 23

Obermuiller's statements reflect an allegiance not only to the Kaiser, but to the Kaiser's political opinions. ${ }^{24}$ Given the historical context in which they are made, the comments of the Offizier der Reserve become typically accurate rhetorical reflections of the political agenda of Kaiser Wilhelm II.

Obermüller's dictation to the Stadtschreiber directly preceding Voigt's uniformed entry into the Amtszimmer des Bürgermeisters is a glaring parody of the anti-intellectual practice of protecting the national language from foreign influence: 
Die Verwaltung einer Stadtgemeinde, deren Hauptkontigent sich aus Industriebevölkerung rekrutiert - oder nein, lassense mal, zuviel Fremdworte - deren Bevölkerungsgroßteil sich aus Industrieangestellten zusammensetzt - zusammensetzt - kann nur nach den Grundsätzen der freisinnigen Sozialpolitik geleitet weden (106).

Dr. Obermuiller's attempt to adhere to the purity of language dictated by Gemanismus leads him to doubt the propriety of the fully German word, "zusammensetzt." Zuckmayer makes clear by example what an inexpedient chore the task of Germanification really is. The passage brings fully to light the discrepancy between Obermuiller's identity as a member of the intelligentsia and his constrained support of the Germanizing agenda of the Kaiser. ${ }^{25}$ In order for the political persona to succeed, Obermüller is compelled to repress the "doctor" in his personality. 26

Zuckmayer's Voigt is almost purely a victim of societal injustice. His natural teenage eroticism leads to punishment admittedly deserved, but in his opinion, too harsh (13 f.). The Voigt of Zuckmayer's drama distinguishes himself above his fellow players with his incomparable power of judgment, which he comes to exercise with unequaled severity upon himself. The voice of God, as revealed to him through his inner voice, is uncompromising in shifting the full brunt of responsibility for his hardship - even down to his "Ausweisung" - onto Voigt himself (91). Through self-deprecation, Zuckmayer's leading character internalizes the societal interdiction against self-gratifying behavior. In contrast to his historical counterpart, he is not only innocent of all criminal intention. Because of his maintenance of human dignity in times of severity, Voigt is an unexampled specimen of the model citizen.

Zuckmayer makes his leading character guilty of nothing but disrespect of divine will as received through the word of God precedent to scene fourteen, where he announces it to Hoprecht: "Und denn, und denn stehste vor Gott dem Vater, stehste, 
der allens jeweckt hat, vor dem stehste denn, und der fragt dir ins Jesichte: Willem Voigt, wat haste jemacht mit dein Leben? Und da muß ick sagen, Fußmatte muß ick sagen ..." (91). He curiously equates his failure to bring his existence to bear against the demands of the Prussian bureaucracy with an infraction of divine justice. But Zuckmayer places social circumstance in the position of prime motivating factor behind Voigt's divine revelation. Voigt announces to Hoprecht his resolve to no longer take things lying down: "Und det Janze? Det Janze, Friedrich, für wem is det? Wat steht hinter, Friedrich, 'n Gott oder 'n Teufel?! Nee, mir hamse zu lang jepufft, mir hamse nu wachjekrieft, da jibt's keen Pennen mehr, ick will det nu janz jenau wissen!!" Voigt's abandonment of his own human ideal as he grasps after the only apparent solution to the predicament of his expulsion is symptomatic not only of his position as victim of societal circumstance. It demonstrates the rising feelings of discontent in a society against which he revenges himself, although by unjust means. For in committing his act of vengeance by marching on a governmental office, Voigt surrenders his freedom into the hands of the real culprit: the military bureaucracy.

Zuckmayer takes the historically dramatic theme concerning an individual's breach of justice and transforms into a form of social conflict. He downplays Voigt's guilt to such a degree, that the bureaucratic system receives the brunt of the blame for his sensational Rathaus coup. But the social conflict Zuckmayer portrays is that of an individual against a politically powerful apparatus of state. His subtly observant neusachlich social analysis centers always on the individual, so it is understandable to see why the main argument of Zuckmayer's Marxist critics centers around the Hauptmann von Köpenick's lack of social critique. ${ }^{27}$ Zuckmayer heightens the socially critical aspect in the dramatic conflict between Voigt and the bureaucracy by transforming them into clearly recognizable representatives of the oppressed-oppressor categories of 
the "soziale Dichtung" genre. ${ }^{28}$ Despite Zuckmayer's adherence to a neu-sachlich form of dramatic presentation, he reflects the spirit of the Köpenickiade's reception in the press to a far greater degree than by sticking to the specific circumstances concerning the actual perpetration of Voigt's Rathaus coup. The coup's motivational impulse comes, in Zuckmayer's interpretation, not from Voigt himself, but from the system. And although the original Voigt was a victim of systematic oppression of sorts, Zuckmayer increases the socially critical aspect of his drama by removing any trace of the actual Voigt's vainglorious intentions in producing the fabulous Voigt, whose sole purpose ultimately becomes nothing more than to reveal the fault within the system. Zuckmayer thus concentrates his attack on the power of Prussian militarism. He portrays its appearance at all levels of society by constructing its presence thematically into every scene, except for one. Of twenty-one scenes, the only scene to exclude the atmosphere of pervasive Prussian militarism is the twelfth scene ("Dachstubenszene"), upon which it intrudes before the "Szenenschluß" in the form of the police order for Voigt's expulsion. ${ }^{29}$ His dramatical interpretation of historical military-civilian relationships descends to the personal level as Zuckmayer brings the fate of the uniform as symbol of military authority into direct contact with the men inside it. Von Schlettow selflessly inflicts the will of the uniform upon himself by relinquishing both uniform and position for attempting to assert his authority out of military dress. Doctor Obermuiller is a bodily representive of the expanding bourgeoisie. His aspirations for political advancement cause him to repress the intellectual spirit in his title in support of the Kaiser's anti-intellectual program of language purification. Zuckmayer's socio-historical criticism of Wilhelmine society attacks the participation of the members of all classes in the prostitiution of the human ideal to military means for the achievement of their various ends. Von Schlettow, 
Obermüller and Voigt - the three estates - repress their true personalities in service to the uniform. They all become victims of the historically resurgent presence of the military. Through Zuckmayer's dramatic vision, the uniform becomes a tool in a selfperpetuating class conflict in which each and every class eventually succumbs to the blind mechanism of an anti-societal military apparatus. 


\section{ENDNOTES}

1Paul Rilla's Marxist critique of the Hauptmann von Köpenick is typical in its condemnation of the drama's failure to provide an adequate criticism of social circumstances. Paul Rilla, "Zuckmayer und die Uniform," Literatur, Kritik und Polemik (Berlin: Henschel, 1950) 7-27.

2Jethro Bithell's short literary historical article summarizes the Hauptmann von Köpenick as "a relentless exposure of Prussian militarism before the outbreak of the First World War." Jethro Bithell, Modern German Literature: 1880-1950 (London: Methuen \& Co. Ltd., n.d.), 406.

3 Jürgen Hein, "Zuckmayer, Der Hauptmann von Köpenick," Die deutsche Komödie vom Mittelalter bis zur Gegenwart, ed. Walther Hinck (Düsseldorf: August Bagel Verlag, 1977) 269.

4Werner Frizen, Der Hauptmann von Köpenick (München: Oldenbourg, 1988) 45. Zuckmayer himself openly admits to the fact in a statement directly following the dramatis personae: "Die tatsächlichen Begebenheiten bilden nur den Anlaß zu diesem Stück. Stoff und Gestalten sind völlig frei behandelt." Carl Zuckmayer, Der Hauptmann von Köpenick: Ein deutsches Märchen in drei Akten (Frankfurt am Main: Fischer Taschenbuch Verlag GmbH, 1993) 5.

5 Siegfried Mews states the position of the latter as follows: "Nur die konservative Neue Preußische Zeitung ('Kruezzeitung'; Motto: 'Vorwärts mit Gott für König und Vaterland') konnte oder wollte in ihrer Abendausgabe vom 18. Oktober 1906 keine Lehre aus dem Fall Köpenick ziehen." The following passage cited in Mews reacts with concern to the political sensation created by the event. It defends the action of soldiers who were only carrying out orders and concludes with the sentence: "Was aber bei den Soldaten begreiflich ist, das ist bei den Herren von der Köpenicker Stadtverwaltung doch kaum begreiflich." Siegfried Mews, Carl Zuckmayer: Der Hauptmann von Köpenick: Grundlagen und Gedanken zum Verständnis des Dramas (Frankfurt am Main, Berlin, München: Verlag Moritz Diesterweg, 1982) 10.

6 Vorwärts, 18. Okt. 1906. Quoted in Mews, 9-10.

${ }^{7}$ Vossische Zeitung, 19. Okt. 1906. Quoted in Mews, 10.

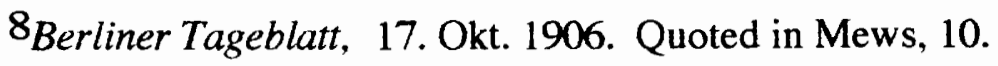

${ }^{9}$ Frizen, 45.

10“'Zuckmayer eliminierte alle Characterziuge, die gegen Voigt einnehmen könnten." Frizen, 45. Surely Frizen, taking the task of literary instruction into consideration, is thinking of something approaching the Neue Sachlichkeit with regards to Zuckmayer's drama and its relation to a contextual categorization. 
${ }^{11}$ Frizen, 46

12 Frizen, 46.

13 Berliner Morgenpost, in Jürgen Hein, 272.

14Wilhelm Voigt, in Frizen, 47, n. 41.

15 Frizen, 47.

16“Königlich priveligierte Berlinische Zeitung” in Jürgen Hein, 271.

${ }^{17}$ Gordon Craig, The Politics of the Prussian Army: 1640-1945 (New York and Oxford: Oxford University Press, 1956) 342, summarizes the enduring power of the Prussian military:

"Not the least remarkable of the attributes of the Prussian army as a political organization was its ability to excape having to pay for its own mistakes. In 1848 , for instance, it had been military abuses which had touched off the risings which took place in Berlin; yet, when the revolution was over, the army had experienced no real diminution of its powers and prerogatives; and, although Prussia was transformed from an absolute to a constitutional state, the military establishment was not forced to submit to any effective measure of civilian control.

Again in 1918 the army was faced with a revolution for which it was largely responsible, and this time the threat to its freedom was far greater than it had been seventy years before. The military collapse which the war-time policies of the Supreme Command had made inevitable released forces which, on 9 November, swept away the dynasty which the army had served since 1640 and transformed the Reich into a republic. Yet once more the army weathered the storm and once more it did so without any real loss of power."

${ }^{18}$ The event could almost as easily refer to the French occupation of the Ruhrgebiet in 1923 and subsequent internal disruptions. The complications involved in such an interpretation are too detailed to warrant further comment here.

${ }^{19}$ Frizen, 49.

${ }^{20}$ Von Schlettow's demotion actually has beneficial consequences for himself. He announces to Wabschke: "Plan jeändert, Wabschke. Werde mal 'n bißchen Landwirtschaft betreiben. Hatte schon immer so was vor. Kleine Erbschaft, Kornklitsche, Pferdezucht, is ja viel besser, aus mitn bunten Rock" (35).

${ }^{21}$ Frizen, 50.

22 Gordon Craig, 233-35. 
${ }^{23}$ Quotation before the Reichstag by the deputy Wirth, Stenographische Berichte, (n.p.: n.p., 1926-27), 8591. In Gordon Craig, 236, cf. n. 2.

24 The possibility of course exists, that many of Obermüller's statements represent a self-expressed irony of the position in which he has placed himself as an officer of the Emperor. But the fact that he never says anything to support such an assumption in the privacy of his own home indicates that he fully believes in the veracity of his self-contradictory statements.

25 Frizen describes the Kaiser's program in the following passage: "Das Neugermanentum des Kaiserreiches perhorreszierte das Lehn- und Fremdwort als 'Überfremdung' und forcierte die 'Eindeutschung', d.h. Anpassung." Frizen, 84.

26"[Obermüllers] Sprache (wie seine Karriere) ist das Ergebnis einer Verdrängungsleistung." Frizen, 84.

${ }^{27}$ The essence of their critique is to be found in the fact that, as "soziale Dichtung," Zuckmayer's drama belongs to the same general category as the Communist dramas of the "sozialistischer Realismus." To the latter movement Zuckmayer's drama definitively does not belong. His critics obviously want to make the distinction clear (see above, page 20, note 1). Wilpert's definition of "sozialer Realismus" begins as follows: "die einheitl. Literaturtheorie der sozialistischkommunistischen Länder, die seit ihrer Proklamation durch M. Gorkij und deren Annahme auf dem 1. Sowjet. Schriftsteller-kongreß 1934 zur maßgeblichen und obligatorischen Doktrin für das lit. Schaffen dieser Länder geworden ist." Gero von Wilpert, Sachwörterbuch der Literatur (Stuttgart: Alfred Kröner Verlag, 1964) 657.

28 Wilpert, 655-66, defines "soziale Dichtung" as a poetic form, "die vom Erlebnis der sozialen Spannungen ausgeht und gesellschaftskritisch zu ihnen Stellung nimmt, in kämpferischem Angriff gegen die Oberschicht, mitleidsvoll von oben herab auf die Geschicke der sozial Unterdriickten, Entrechteten und Verachteten blickend oder in Verbindung beider Haltungen." Zuckmayer's compassionate treatment of Schlettow and Obermüller as well as Voigt in no way represents a "Verbindung beider Haltungen" of Wilpert's definition. The "Oberschicht" of Zuckmayer's conflict cannot be defined in terms of class. It is the military bureaucracy as system in and of itself, of which he is uncompromisingly critical.

29Jürgen Hein, 275, describes the twelfth scene as "Ruhepunkt in der Handlung und als Sperrung gegen die Szenen II, 11 (Ohnmacht der Bürger vor den Befehlen des Militärs) und II, 13 (Festsouper bei Dressel; Mädchen in Uniform). .." 


\section{STRUCTURE OF THE PLOT}

That the composition of Zuckmayer's Hauptmann von Köpenick relies upon an intensive attention to structure is acknowledged by the author himself. In a questionaire sent to him by a student of his literature, he speaks "von dem Hauptmann von Köpenick als einem symphonisch durchbauten Stück." ${ }^{1}$ Zuckmayer chooses a figure from contemporary history about whom to construct his plot. Wilhelm Voigt's notorious act of deception concluding with the confiscation of the treasury funds of the Rathaus in Köpenick on October 16, 1906 is an event still fresh in everyone's minds twenty-five years after the fact. The author of the drama of 1931 preserves the spirit of the original event's popularity by removing the element of criminal intent from a treasonable breach of justice. Zuckmayer's alteration of the character of Voigt distinguishes him as a poet actively at work in forming his dramatic material - an idea closely related to his notion of unity between the individual, the world and divine justice. Voigt is the microcosm of such a Weltbild. He achieves completion in active determination of his circumstances. He achieves true identity and spiritual unity in opposition to the Prussian system of military bureaucracy. But by actively partipating in the determination of his status in the community, Voigt makes the long-delayed transition into the world of human affairs. The first act establishes Voigt's exclusion from society. The first, second and fourth scenes are the repetion of an archetypal event in which Voigt's requests for a residence permit and work are peremptorily rebuffed. Voigt reaches the decision to take matters into his own hands in the second act. He executes his plan of arch-deception in the final act. Zuckmayer places the audience beyond the region of dramatic action and shuts the first and third acts off from the cardinal second act. The first act is a demonstration of Voigt's apparent guilt before the system. The third act is an enactment of his apparent legitimacy. Society 
determines the first state of affairs. Voigt's act of deception determines the appearance of legitimacy. The second act divides the diametrically opposed states of affairs constituted by the first and third acts of the Hauptmann von Köpenick. The second act serves as a meeting point between the central dramatic themes of exclusion and integration, escape and invasion. The eleventh scene brings the archetypal exclusionary event to a climax. The themes of societal integration and bureaucratic invasion intersect in the secluded garret room setting of the twelfth scene. The eleventh and twelfth scenes interact on multiple levels as polar elements of the dramatic core. The dramatic core elevates the societal significance of the family. The family structurally embraces the core until a rupture makes itself evident in the fourteenth scene. The determined unidirectionality of the third act takes up the slackened tension of the monotone first act to tighten the intricately interwoven knot of dramatic intensity in the second act. Zuckmayer employs his talents of composition toward the achievement of a masterpiece of intercharacter relationships and thematic variations. He completes the structural whole through a multilevel connection of internal dramatic components to the mystical world of numerical formulæ.

Zuckmayer's attention to form extends beyond the literary work. As an agent of poetic transformation, he asserts his formative capabilities upon his subject matter. The tendency to radically reinterpret the characters he took from history must have become quite evident to the Weimar audience for whom he composed Der Hauptmann von Köpenick. He now chose a figure with whose deeds it was generally still highly familiar. ${ }^{2}$ His active exercise of the transformative technique with respect to Voigt reveals the poet, Zuckmayer, as every bit a participant in the structuralist task:

La structure est donc en fait un simulacre de l'objet, mais un simulacre dirigé, intéressé, puisque l'objet imité fait apparaître quelque chose qui restait invisible, ou si l'on préfère, inintelligible 
dans l'objet naturel. L'homme structural prend le réel, le décompose, puis le recompose ... ${ }^{3}$

Zuckmayer's Voigt is thus radically different in every way from the Voigt upon whom he bases his drama. 4 In her dissertation on the Hauptmann von Köpenick, Sibylle Werner concludes that Zuckmayer has altered the actual events in favor of a higher reality: "It has been attempted to show that in a drama the actual facts can be altered to suit the purpose of the author as long as the new world that has been created is right and lives according to its own laws." 5 But the world Zuckmayer creates in the Hauptmann von Köpenick is by no means perfect. The world he dramatically presents is a soberingly true-to-life reflection of a republic attired in the trappings of military absolutism.

The "structural concept" of the Hauptmann von Köpenick is the product of its author's metaphysical convictions. ${ }^{6}$ The symmetry of Zuckmayer's plot construction is a reflection of his Weltbild, if perhaps not Weltanschauung: "Als ganze ist die Welt 'rund,' geordnet in einer umfassenden Symmetrie und Harmonie."7 Zuckmayer's conception of the world includes the principle of individual participation in the task of creation. That it contains the ideological principle of democratic participation is exceedingly obvious:

Es kommt auch auf Dich an. Auf Dich, aufs Ich, nicht als isoliertes Zentrum, in die Irrenzellen der Selbstumkreisung gebannt, - auch nicht als namenlosen Bestandteil einer Quantität - sondern als ganze runde Welt, einmaliges organisches Wesen, einbezogen ins vieltönige, orchestrale Koordinatensystem des Irdischen und des Außerirdischen, Geschöpflichen und Schöpferischen, Göttlichen und Menschlichen. Es kommt auf Dich an, - in Deiner Gegenwart, die unsre einzig erfahrbare Größe, in der Zeit und im Raum, darstellt, und unsern einzigen Weg zu einer überzeitlichen Einheit. 8

Zuckmayer applies a similar circular construction to his treatment of Voigt's character and Werdegang. He applies the same scheme to his treatment of the plot and his own 
dramaturgical relationship to his audience. Zuckmayer performs an act in reconstitution of worldly unity in the closing scene of the Hauptmann von Köpenick. Voigt's laughter, "mit dem ganzen Körper, aus dem ganzen Wesen" (128), represents the unity of body and spirit. It is "alles zusammenfassend" and directed toward the audience. It forms a unity between himself, his worldly and divine creator, and - in truly catholic fashion - the audience. Zuckmayer's structural conception is the expression of his belief in the active reponsibility that democratically binds the individual to the immediate worldly environment as well as to the divine.

A principal underlying component of Zuckmayer's drama lies in the metaphysical picture of wholeness presented to Voigt through the inner vision he receives before the fourteenth scene. God's demand to know what Voigt has done with his life amounts to a command to the achievement of spiritual completion through action (91). The irony lies in the fact that Voigt achieves psychological wholeness by adopting a self-disconnected outward aspect that conditions have inadvertantly forced upon him. Voigt's Erkenntnis comes in two stages. He becomes aware of his predicament at the structural center of dramatic action of the Hauptmann von Köpenick. Yet he achieves full self-completion in the final moment of selfcapitulation and reckoning openly avowed to the theatrical audience in his final spoken line: "unmöglich" (128). The underlying reality of Voigt's final revelation is his perception that there was never anything wrong with him to begin with. He has seen the world on the other side of the military-bureaucratic walls. He was made no freer by the uniform. By offering himself over to the authorities, Voigt restores his original sense of wholeness.

Voigt attains natural wholeness only in opposition to the closed uniformity of the system that allows him neither a residence permit nor passport. Voigt, "der arme 
Teufel," is confined to the "Selbstumkreisung" of Zuckmayer's description (see above, page 39). Voigt describes the vicious circle of his predicament in the second scene: "Nee, nee, det is nu'n Karussell, det is nu ne Kaffeemihle. Wenn ick nich jemeldet bin krieg ick keene Arbeit, und wenn ick keene Arbeit habe, darf ick mir nich melden" (16). ${ }^{9}$ Not until he breaks the Teufelskreis of a bureaucratic ban, both resulting in unemployment as well as from it, does Voigt gain respect from his societal peers. Only by surrendering himself over to the authorities does he obtain the promise of a legitimate place in society. The perpetual eccentricity of his existence serves as evidence of the societal disharmony created when its civilian and military spheres remain unresolved. ${ }^{10}$

Zuckmayer emphatically places the audience beyond the dramatic activity of his play, to whom Voigt visually directs himself and ultimately delivers his epigrammatic statement: "Unmöglich!!" (128). But the Kaiser also remains beyond the events. Voigt surrenders in the final scene. The inspector mediates the Kaiser's secret words in print: "Habense den Geheimbericht nich gelesen? Gelacht hat er, wie man's ihm vorgetragen hat, und stolz war er nocht drauf! Mein lieber Jago, hat er zum Präsidenten gesagt, da kann man sehen, was Disziplin heißt! Kein Volk der Erde macht uns das nach!" (121). For the spectator of 1931, the repetition of the Kaiser's remark of 1906 must have had an ominous effect upon Zuckmayer's audience. ${ }^{11}$ Kaiser Wilhelm II, having fled the country in 1918 , was still very much alive, although excluded from all determination of political events within Germany. Zuckmayer reflects the contemporary public state of affairs in Weimar Germany by excluding the Kaiser from any visible controlling role. Yet the Kaiser's cryptic statement stands like an epitaph on the headstone of the Weimar Republic. For it openly acknowledges the enduring presence of monarchic tendencies as a surviving 
institution. ${ }^{12}$ Zuckmayer places the power of public decision and monarchical opinion beyond the realm of the obviously bureaucratically controlled events of his drama. He is calling for an objective reevaluation by the public of its stance within the Weimar Republic. ${ }^{13}$ Zuckmayer's neu-sachlich dramatic presentation furnishes a vividly comprehensible abstraction of the prevailing political trends threatening the shortlived democratic tradition of Weimar. But the public of his day was used to overt ideological statement. Symbolic language such as Zuckmayer's was losing its significance. The "kommt mit" of Zuckmayer's quotation from the Brothers Grimm forms a bond between Zuckmayer and his audience. But the bond appears in retrospect nearly resigned, fatalistic or escapist. His style tends to reinforce the opinion that the unengaged objective reflection on current political phenomena is still valid. But by 1930 , objective deliberation on affairs had grown dangerous to the survival of the trend it most supported.

Zuckmayer conceptualizes the plot of the Hauptmann von Köpenick on a symmetrical axis. The construction of the plot is circular in the second act, rotating about the events of the eleventh and twelfth scenes in imitation of Zuckmayer's "Weltbild" illustration of the bond linking humanity to the Kosmos. ${ }^{14}$ Between the central core and outer concentric circle is another concentric circle formed by scenes ten and thirteen. Passing out of the rings of the dramatic center, one emerges in the commencement of the third act: scene fifteen. From the fifteenth scene on, the plot again proceeds along linear lines until its conclusion. 15 The first and third acts of Zuckmayer's drama are linear projections radiating in and out of the spherical dramatic core of the second act.

The Weltbild structure of Zuckmayer's drama, with its concentric rings, sharply draws out the distinction between outward appearance and Innerlichkeit. ${ }^{16}$ 
The area excluded by the closed perimeter of the second act represents the combination of societal components in the public realm versus the closed spheres of its segregated components. Each scene of the Hauptmann von Köpenick takes place in either the public, bureaucratic or private sphere. ${ }^{17}$ But in the first act, the public and bureaucratic realms combine to form a private space excluding Voigt. The action of the first act moves from beyond the perimeter into the circular second act, then emerges once again on the outside as it proceeds toward the conclusion. In the second act (eighth through fourteenth scenes) the bureaucratic, public and private spheres separate more completely from one another. Zuckmayer brings the themes of acceptance and rejection to a peak. The commencement of the third act transmits the action once again into the public-bureaucratic realm, where it remains up to the finish. Voigt's apparent guilt in the first act drives him deep into the secluded spherical core of the second act. The uniform lends Voigt the appearance of legitimacy in the third act. The public-bureaucratic combination is no longer to exclude the Voigt-uniform pair from its protected inner realm.

The Weltbild schema thus acts to mediate as a closed internal structure between the outward aspects of public guilt and legitimacy. By closing off the second from the first and third acts, it is the hinge about which the three-fold dramatic breakdown becomes poetic reality. The peripeteia lies at the core of the second act. It divides the dramatic action into two directional halves representative of the thematic processes of exclusion and inclusion. Seclusion represents the space of the second act. The plot carries Voigt deeper and deeper into the secluded familial sphere. The forces of police bureaucracy disrupt the spiritual harmony of the (twelfth) "Dachstubenszene" by invading its privately secluded atmosphere with Voigt's order of expulsion (77-78). Repeated Ausgeschlossenheit leads Voigt back to his family roots, to the 
Eingeschlossenheit structurally represented in the circular perimeter formed by the familial ninth and fourteenth scenes. The Ausweisungsbefehl repeats the theme of Aussgeschlossenheit of the first, second, fourth and eleventh scenes. ${ }^{18}$ With Liesken's death, Voigt retreats to the Innerlichkeit, to the secluded realm of his thoughts. Here he receives his Offenbarung (91). Through divine revelation, Voigt reaches the state of Entschlossenheit he demonstrates to Hoprecht in the fourteenth scene. The Weltbild construction divides the dramatic space of the Hauptmann von Köpenick into public and private on varying levels. The processes of exclusion and inclusion, invasion and escape describe the dramatic conflict between the forces of bureaucracy and Voigt's desire for liberation.

The internal delimitation of dramatic components is elemental to the structure of Zuckmayer's drama. As closed dramatic structural components, the eleventh and twelfth scenes interact at multiple levels. The twelfth scene ("als Ruhepunkt der Handlung" and "Märchenintermezzo") acts as a "Sperrung" against the eleventh and thirteenth scenes. ${ }^{19}$ In the eleventh scene, the "Blick durchs Schlüsselloch" of the police station in Rixdorf instructs Voigt in the possibilities offered by wearing a uniform. ${ }^{20}$ It symbolically represents the first stage of his intrusion into the secret bureaucratic space of the system closed against him. The twelfth scene ("Dachstubenszene") is "der Integrationspunkt und die Peripetie (der Umschlag der Handlung in ihr Gegenteil) nicht nur des Zweiten Aktes, sondern des Dramas uberhaupt." 21 Liesken is a societal victim in a Naturalistic tragedy in contrast to Voigt, who saves himself with a fabulous salto mortale into the "slapstick comedy" of the third act. ${ }^{22}$ The "rührende Elemente" (e.g. "Dachstuben-atmosphäre") and the expulsion order represent the Heimat-Thema on two levels. But the dramatic reversal is only indicated or foreshadowed at this point. ${ }^{23}$ In the twelfth scene, Voigt's efforts 
center on sheltering Liesken from the outside world, on secluding her through the fantasy of fairy-tale from her impending death. Liesken perhaps attempts to preclude Voigt from facing a similar fate when she begs him, "Nich wechjehn!!" (76). The dual "Heimat" motif represents the thematic opposites of acceptance and rejection, which in all of Zuckmayer's work naturally relate to "Heimat" on varying levels. ${ }^{24}$ The eleventh and twelfth scenes together form a contrast between objective curiosity (peeping through the keyhole) and the deeply subjective reflection into which Voigt is driven upon Liesken's death. Both events are directed away from the stage. Voigt's almost scopophilic curiosity with respect to the secret of the uniform directs itself into the mysterious guarded realm of bureaucratic Sachlichkeit behind the keyhole. ${ }^{25}$ After Liesken's death following the twelfth scene, Voigt descends into the personally subjective sphere of his innermost thoughts. A divine voice reveals the secret meaning behind his bureaucratic maltreatment. Both events direct the audience's attention through identification with Voigt into the the space behind the Bilderbogen façade Zuckmayer presents to it. The eleventh and twelfth scenes contrast on the basis of exclusion and seclusion. The eleventh scene draws Voigt's gaze into the objective beyond. Following the twelfth scene, his gaze is directed into the realm of highest subjectivity, demanding that he account for his actions. Voigt visually invades the private space of the bureaucracy in the eleventh scene. In the twelfth it invades Voigt's privacy with an order excluding him from its public territorial realm. The notable division of the eleventh and twelfth scenes into independent dramatic units increases their possibilities for thematic interplay.

Zuckmayer encloses the pivotal twelfth scene within a perimeter formed by the family. The familial enclosure formed by the ninth and fourteenth scenes stresses the human environment as the sphere in which important decisions are made. A structural 
analysis of the Hauptmann von Köpenick's second act in terms of Weltbild describes the tenth and thirteenth scenes (enclosing "das kleinbuirgerliche Trauerspiel" core) as a farcical dramatization of gentle bourgeois society. ${ }^{26}$ The outer concentric circle embeds the tenth through thirteenth scenes "in das - nach Zuckmayers Perspektive - eindeutig bewahrende und heilende Element, die Familie." Zuckmayer's structure provides the key to the location of Voigt's internal revelation by enclosing its dramatic space within familial scenes: "Das Humanum sollte in der natürlichen Gemeinschaft des Menschen geborgen sein." 27 Heimat and family are significant themes in the works of Zuckmayer. But in the Hauptmann von Köpenick, Voigt's return to family differs a great deal from his reception in the local offices of bureaucracy. After hearing of his difficulty with the "Behörden," Hoprecht offers him shelter until "de ne Anstellung hast" (63). But when Voigt departs, the only significant difference between his treatment by the bureaucracy and by the remaining members of his family is one of degree. His brother-in-law Hoprecht's capping statement upon Voigt's departure from the family (resulting from the local "order of expulsion") is purely sachlich in its absense of empathy for a brother-in-law's despair over the system: "Der Mensch - der Mensch is ja gefährlich!!” (92). Zuckmayer demonstrates the power of a bureaucracy to unjustly divide society at its roots. The last remaining members of his family receive Voigt into their home with open arms, but when he must depart, they do not bid him farewell with anything but Sachlichkeit. Zuckmayer emphasizes the societal importance of the family through ironic negation: Voigt's final treatment within his sister's family is a sachlich reversal of the ideal family relationship.

The flat construction of the first and third acts forms the foundation upon which Zuckmayer builds the structurally complex second act. The first act is fully sachlich in its swiftly moving realistic portrayal of social circumstance and usage of 
natural dialect. But structurally, it is a repetition of Zuckmayer's first drama, Kreuzweg, "konzipiert noch im Schema des expressionistischen Stationendramas, das Stationen episch reiht und auf die dem Drama eigene Zielgerichtetheit verzichtet."28 The last act comes under the category of "slapstick comedy." Zuckmayer noticeably abandons the closed-scene technique that combines scenes into the complex relationships upon which he constructs the preceding plot. With the exception of the sixteenth scene, each scene leads directly into the next, through to the completion of the Köpenickiade in the nineteenth scene. The drama "wird zum Ende hin seinem Eigengewicht überlassen, die Dynamik aus dem historischen Ereignis gewonnen." 29 In the fifteenth scene, Voigt buys the old uniform for an alleged "Maskenball" (93). The sixteenth scene ends with Voigt in captain's uniform, demonstrating his position by having the pair of railway officials execute his commands. Voigt's "Vorwärts marsch" concluding the eighteenth scene (106), carries the action directly over into the nineteenth, in which Voigt concludes his Rathaus coup. The stagnantly flat construction of the first act is like a barrier in which each scene interlocks with the next to continually close Voigt out of society. The third act demonstrates Voigt's mental conviction through its employment of a unidirectional plot-line leading directly into the office of Buirgermeister Obermuiller. ${ }^{30}$

The structure of Der Hauptmann von Köpenick is so intricate, that a great variety of comparisons present themselves on all levels. The dual plot relationship of the uniform and Voigt contitutes one of the principal structural ingredients in the plot of the Hauptmann von Köpenick. It has been exhaustively treated in other interpretations, so here no attempt will be made to give it extensive structural treatment. ${ }^{31}$ Yet it should be noted that, just as Voigt's plot-line follows a circular pattern, "Der zweite Handlungstrang, der von der ersten Szene ausgeht, vollzieht 
ebenfalls die Figur des Kreises." 32 The uniform's circulation between owners makes a direct comparison between them inevitable. The contrasts and similarities between individual figures indeed provide the possibility for an in-depth character analysis that will not even be attempted here. Zuckmayer's careful attention to dialect and individual character traits causes each of the seventy-three characters of the Hauptmann von Köpenick cast to stand on their own. The tendency becomes nowhere more evident than in the sixth scene, in which characters from all parts of Germany come into contact with military-bureaucratic officials in the "Herberge zur Heimat" (36-47). Each character distinguishes himself with his distinctive regional dialect and traits. The same holds true for each analytical division of Zuckmayer's drama. "Die offene Form des Dramas verbindet sich mit Strukturprinzipien der Geschlossenheit; die episch angelegte Bilderfolge, nicht selten satirisch erzählend, wird zum Schluß auf die für Zeit und Gesellschaft prägnante Pointe zugespitzt."33 Zuckmayer presents each character, scene and act of his drama as a closed entity, thus maximizing the possibility for their interrelationship within the text of the Hauptmann von Köpenick.

Zuckmayer's integration of mystical numerical significances into the structure of his drama forms the bond with which he links it to the world of Märchen:

Das Gliederungsschema (drei mal sieben Szenen) billigt dem Untertitel (ein deutsches Märchen) strukturbildende Funktion zu. Durch die Zahlenmystik schon läßt Zuckmayer erkennen, daß er den Gesamtrahmen der Handlung als Märchen verstanden wissen will. 34

Zuckmayer repeats the three-fold breakdown of the plot in the triple relationship of Schlettow, Obermuiller and Voigt as consecutive owners of the uniform. He further divides the stage settings into three separate classifications: private, public and "amtlich polizeilich." 35 His construction of the first scene reflects the same tripling of internal elements: 
Drei sind die Leidensstationen Voigt's, dreimal steht er vor den Schranken, dreimal scheitert er, dreimal wird die Uniform anprobiert, in drei Stationen läuft auch Schlettows Schicksal ab, dreimal wird die Uniform 'degradiert' (durch Schlettows Verhaftungsversuch, durch den betrunkenen Grenadier, durch den Deserteur). ${ }^{36}$

Zuckmayer forms triple interrelationships of character, setting and event with which to express the opposition of acceptance and rejection on at once a personal and then purely sachlich level with respect to Voigt and the uniform. "Die Drei bestimmt das Baugesetz des Märchens, das Zuckmayer im ersten Akt am konsequentesten durchhält. Dem Zauber der Uniform entspricht der Zauber der Struktur."37 The triple structure of Zuckmayer's Märchen in drei Akten prepares the ground on which its interaction with the world of fairy-tale becomes possibility.

Zuckmyaer's metaphysical concept of world unity manifests itself not only in the treatment of his leading character, but in the structure of his drama as well. Zuckmayer changed motivational attributes in the character of the historical Wilhelm Voigt to suit his Weltbild metaphysical and dramatic concept: a practice indicative of the formative task of structuralism, in Barthe's definition. Voigt is Zuckmayer's Weltbild in miniature, confined to orbit in a vicious circle between the disunity of the civilian and military-bureaucratic sectors of society. He performs his Rathaus coup in an attempt to fulfill the "deepest need of man, ... to overcome his separateness, to leave the prison of his aloneness." 38 Voigt reestablishes his unity and integrity, not in opposition to society, but through surrender to its institutions of justice. The laughter he directs toward the audience in the closing scene underscores the division between dramatic activity and the passive spectator. But it acts as a bridge through which the world of theater integrates itself into the public sphere of reality. The laugh reconstitutes the all-embracing harmony of Zuckmayer's Weltbild. The plot of the Hauptmann von Köpenick is conceived about a symmetrical representation of the 
Weltbild located at the dramatic core. It divides the two worlds of appearance represented by the first and third acts. The second act transforms Voigt's apparent guilt before the law into apparent legal legitimacy founded on the strength of his resolve and the means within the system. The second act brings the conflict between societal inclusion and bureaucratic exclusion to a head in the diametrical opposition of the eleventh and twelfth scenes. The private realms of both are ruptured through intrusion, first by Voigt and then by the bureaucracy. The familial perimeter encloses the space of the peripeteia, through which it too undergoes a Wendung. Voigt's warm reception into the family in the ninth scene switches over into a cooly objective farewell in the fourteenth. The bureaucratic principle of divide et impera causes the familial rupture. The disconnected scenes of the first act slacken the pace of Voigt's development as they rapidly and indeliberately close the societal barricade against him. The structural intricacies of the second act taughten the dramatic tension into a tightly interwoven Verflechtung der Handlungsstränge. 39 The knot of dramatic tension unravels into the third act as Voigt marches scene by scene toward the inner chamber of the Rathaus in Köpenick. Zuckmayer's compositional talents allow for a maximum of interpretational solutions to the intricate details of his plot. The unified three act construction repeats itself in triple parallels of plot-line, event and character relationships. It forms the Hauptmann von Köpenick's primary structural bond to the world of Märchen in reiteration of the tripartite unity that descends to all levels. 


\section{ENDNOTES}

1 Ingeborg Engelsing-Malek, ${ }^{*}$ Amor Fati in Zuckmayers Dramen (Berkeley and Los Angeles: University of California Press, 1960) 176, n. 12.

2In composing the events for his 1927 drama, Schinderhannes, Zuckmayer transformed the "Wegelagerer," Johann Bückler, into "den edlen Räuber, der ein Helfer der Armen ist." His version corresponded closely to the spirit of the folk tale that had grown around the figure of Buickler following the revolt of the Silesian weavers of 1844. Thomas Ayck, Carl Zuckmayer: in Selbstzeugnissen und Bilddokumenten (Reinbeck bei Hamburg: Rowohlt Taschenbuch Verlag, 1977) 68.

${ }^{3}$ Roland Barthes, Essais Critiques (Paris: Éditions du Seuil, 1964) 214.

${ }^{4}$ Werner Frizen, Carl Zuckmayer: Der Hauptmann von Köpenick (München: Oldenbourg, 1988) 45-48. See above, page $20 \mathrm{ff}$.

5 Sibylle Werner, "Der Hauptmann von Köpenick, Wirklichkeit und Dichtung am Beispiel des Dramas von Carl Zuckmayer," (University of Maryland, 1954), 402. Quoted in Engelsing-Malek, 48, n. 2. Zuckmayer demonstates his awareness of the Zeitumstände in the following passage over the Hauptmann von Köpenick: "Das Stück wurde, von Freund und Feind, als Politikum begriffen, als das es gemeint war. Und bis jetzt waren die Freunde, wenigstens unter dem Teil der Bevölkerung, der überhaupt ins Theater geht oder liest, noch in der Überzahl. Gerade daß hier auch die 'Gegenseite', das Militär vor allem, nicht blindlings verdammt und verteufelt, sondern mit dem Versuch zu dramatischer Gerechtigkeit dargestellt wurde, machte das Stück und sein Anliegen glaubwürdiger und ließ nicht das Mißtrauen und den üblen Nachgeschmack aufkommen, den betonte einseitige Tendenz oder 'Propaganda' immer verursacht." Carl Zuckmayer, Als wär's ein Stück von mir: Horen der Freundschaft (Wien: S. Fischer Verlag, 1967) 444. Cf. note 33 on page 74.

6Frizen, 40. Frizen thus completes the circle of his argument, which is in no way circular, by connecting the disjointed "Einfälle," upon which Zuckmayer depends for dramaturgical inspiration, to the mental picture underlying Zuckmayer's productive concepts, or so it at least appears. Zuckmayer's portrayal of the natural in his work is so immediate, that Wolfgang Paulsen disregards any metaphysical underpinnings: "Der reinen, und zwar ganz und gar unmetaphysischen Zustimmung zu Natur wie Leben verdanken wir einige der schönsten Szenen in Zuckmayers Werk ..." Wolfgang Paulsen, "Carl Zuckmayer," Deutsche Literatur um 20. Jahrhundert: Strukturen und Gestalten (Bern: Franke. 1967) 1: 302.

7Frizen, 40. Herbert Jhering's generally favorable reception of the premiere of Zuckmayer's play nonetheless condemned it for failing to offer a clear "Weltanschauung" to its audience. See below, page 60.

8Zuckmayer, Die langen Wege (Frankfurt: S. Fischer, 1952) 45. 
9Werner Frizen attributes (somewhat rhetorically) Voigt's repeated rejections and expulsions to the ubiquitous "Prinzip Uniform." Frizen, 21.

10 In describing the regulations for the expansion of the army, or "Heeresergänzungsbestimmungen," of June 1921, Gordon Craig states: "These provisions were applied in such a way as to exclude Jews, socialists, communists, and even outspoken democrats from the army." Gordon Craig, The Politics of the Prussian Army: 1640-1945 (New York and Oxford: Oxford University Press, 1956) 394. In response to the Versailles Treaty's limitation of the German army to 100,000 troops, the German military had shifted many of its troops into the Sicherheitspolizei, and then into the Ordnungs- and Schutzpolizei units. Craig, 404-405. This development surely had an impact on the relationship between the police and citizenry under Weimar, especially in terms of police indifference to right-wing attacks against racial minorities and members of the political left, which were later institutionalized under the Third Reich.

11 The Kaiser's approval of Voigt's escapade rests upon the actual event. Zuckmayer's representation of the fact within his fabulous reworking of the events is not easy to interpret. But within the simple analogy of the ever-present uniform, the message becomes doubly clear. As just another man, the Kaiser would have realized the sheer humor in the ability to command on the basis of purely outwardly vested authority. Yet placing oneself within the immediate period to which the author of Der Hauptmann von Köpenick meant to refer, one sees a monarch deposed by the arbitration of might - a deposed leader who would have gained the last laugh upon seeing anyone reestablish total sovereignty through dutiful adherence to the militaristic precedence of Prussian might. The same "might" that remained the "may as-well-be" through which Hitler claimed hegemony over German sovereignty.

12 The former emperor died in 1941. Following the discovery by police of secret plans for an SA seizure of power in the event of a Hitler election victory in late March 1932, a decree had been formulated for the dissolution by force of the armed Nazi Kampfbrigaden. Crown Prince Wilhelm communicated his dismay to Reichswehrminister Groener that the latter should desire the destruction of "the wonderful human material that is gathered together in the S.A. and S.S. and which is getting valuable training there." Lieutenant-General Wilhelm Groener, "Groener Correspondence: Crown Prince to Groener," 14 April 1932. Quoted in Gordon Craig, 450, n. 3. Schleicher subverted the order, and it was never carried out. Craig, 449-50.

${ }^{13}$ It seems probable that Zuckmayer recognized the dilemma with which German politics were faced without wholly realizing his personal responsibility for open engagement on the side to which he was most proximate. It seems indeed reasonable that he viewed the anti-fascist message present in the Hauptmann von Köpenick as a sufficient contribution to the early resistance effort against Hitler's forces, particularly in view of its popular reception. The assumption that his audience in no way fully comprehended the gist of his message is evident enough in the reports of his critics, for neither did he. The reluctance in figures like Zuckmayer's showing of open political resistance to Nazism by joining the "Eiserne Front" could only have served to support the prevailing public sentiment of fatality in the face of the threat 
posed by the growing ranks of the highly conservative "Harzburger Front." Cf. Carl Zuckmayer, Als wär's ein Stück von mir, 451.

14Frizen, 40 . See also note 15 directly below.

15Frizen, 24, 28 and 37 offers three diagrams to serve as reference to his structural analyses. He provides a diagram in which the first eight scenes linearly approach the outer concentric circle (composed of scenes nine and fourteen) and surround the eleventh-twelfth scene dramatic core.

16Frizen's model is similar in conception, although less complicated in outline than that of Jürgen Hein, who places the eleventh scene at the dramatic core. Hein provides four sources of influence upon Zuckmayer's choice of dramatic form: "Kortners ursprüngliche Anregung zum Film-Drehbuch, Nachwirkungen des expressionistischen Stationendramas, Piscators Theater und die Erneuerungsversuche des Volksstückes in der Weimarer Zeit finden ihren Niederschlag im bilderbogenartigen, filmischen Aufbau des Dreiakters, dessen einundzwanzig Szenen symmetrisch um die Achse der 11. Szene (II) montiert sind und durch Auf- und Abblenden, Wechsel des Schauplatzes usw. gegeneinander abgegrenzt werden." Jürgen Hein, "Zuckmayer, Der Hauptmann von Köpenick," Die Deutsche Komödie vom Mittelalter bis zur Gegenwart, ed. Walther Hinck (Duisseldorf: August Bagel Verlag, 1977) 274. Hein appears to have originated the symmetrically circular concept. Frizen undoubtedly chooses to avoid any confusion between their systems by only referencing Hein's article once in his chapter on "Aufbau" in order to describe the latter's breakdown of the scenes into three levels: "Jürgen Hein weist nach, daß auch die Handlung auf drei Aktionsebenen verläuft." Frizen, 31, n. 21.

17Jürgen Hein, "Zuckmayer, Der Hauptmann von Köpenick," Die Deutsche Komödie vom Mittelalter bis zur Gegenwart, ed. Walther Hinck (Duisseldorf: August Bagel Verlag, 1977) 278.

18Frizen, 26.

19Hein, 275.

20 Hein, 275. Voigt's peep through the keyhole becomes in Frizen's interpretation a last opportunity, "in das Allerheiligste der Amtsstube zu blicken: eine letzte Pantomime der Auswegloigkeit." Frizen, 26.

${ }^{21}$ Frizen, 27. Frizen also adds that "die Peripetie-szene den Antagonismus von Held und Gesellschaft so zugespitz, daß nur noch das Trauerspiel möglich erscheint."

22Frizen, 27. Frizen of course uses the English-American designation for the comedic trend that originated in the Italian theater but has been popularized by Hollywood. 
23"Überdies deutet die Konzentration der privaten Szenen im zweiten Akt den Umschlag bei Voigt von der getretenen Kreatur zum handelnden Subjekt an." Hein, 275.

24For an in-depth discussion of the "Heimat" theme in Zuckmayer's life and work, cf. Jochen Becker, Carl Zuckmaver und seine Heimaten: Ein biographischer Essay (Mainz: Verlag H. Schmidt, 1989).

25 Voigt slowly becomes infected by fetishism directed at the uniform.

26“Farce, die die gutbürgerliche Gesellschaft aufführt ..."Frizen, 28.

27 Frizen leaves this observation with no supporting citation.

28Frizen, 19-21.

${ }^{29}$ Frizen, 29-31.

30Frizen, 29.

31 Hein observes that Voigt appears in all but four of the twenty-one scenes and in every scene after he is united with the uniform. Hein, 274.

32Frizen, 21. For discussions of the uniform as a leading figure in the Hauptmann von Köpenick, see esp. Ayck, 94-95; and Engelsing-Malek, 49-50..

33 Hein, 278.

34Frizen, 31 .

35 Hein, 275.

36Frizen, 31 .

37 Frizen, 31 .

38Erich Fromm, The Art of Loving (New York: Bantam Books, 1956) 8.

${ }^{39} \mathrm{Cf}$. Frizen, 39. 


\section{MÄRCHEN AND VOLKSSTÜCK}

Zuckmayer had been working on a dramatic concept that would unite fable and contemporary events since receiving the dramatic prize of the Heidelberger Festspiele in 1929. As Zuckmayer describes: "The prize carried no obligation, but it was hoped that the prize winner would write a play suitable for performance at the Festival."1 Earlier performances at Heidelberg had been limited to "Glanzinszenierungen" of great works in world literature. But in hopes of acquiring "die dafür passenden Stücke" in contemporary literature and theatrical premieres, the bestowers of the prize turned generously to Zuckmayer and two other popular dramatists. ${ }^{2}$ The reception of the Dramatikerpreis in Heidelberg thus provided Zuckmayer with the impetus for composing a drama that would fulfill the literary traditional requirements of the Festspiele while being modern at the same time.

Zuckmayer planned on employing an Eulenspiegel figure in a comedy of rhymed verse fit for performance at the festival. He further intended upon lighting upon a particularly modern theme. Zuckmayer regarded the script of Kakadu-Kakadu and the adaptations of Anderson and Stallings' What Price Glory and Heinrich Mann's Der Blaue Engel merely as "Handwerksarbeiten, Fingerübungen, Etüden."3 He describes the difficulty of accomplishing the projected task:

Aber der 'Eulenspiegel', den ich als meinen dramatischen Hauptplan betrachtete, kam nicht vom Fleck. Er scheiterte, mußte scheitern, an der Diskrepanz zwischen dem Vorwurf des alten Volksbuchs, an das ich mich zu halten versuchte, und der Zeitnähe, dem Gegenwartsgehalt, der lebendigen Wirklichkeit, die ich erstebte. ${ }^{+}$

Zuckmayer thus intended on combining traditional fable with a commentary upon the reality of the times.

By combining fabulous elements with those of satire in Der Hauptmann von Köpenick, Zuckmayer distances his drama from contemporary events to a degree that 
allows it to serve as a metaphor for the times. Zuckmayer's subtitle, "ein deutsches Märchen," is a "contradictio in adiecto." The "Zeitlosigkeit des Märchens und die Zeitgebundenheit des deutschen Wesens schließen sich aus."5 Zuckmayer's drama takes a recent historical event as theme and translates it into fable. The full impact of the contradiction comes with reading its title from beginning to end: Der Hauptmann von Köpenick: ein deutsches Märchen in drei Akten. Zuckmayer's title is like a parody of headlines often found in the ideological press, which take their ideological preconceptions and present them as political fact. Zuckmayer reverses the tendency, taking historical fact and headlining it in fabulous terms. He imbues his "deutsches Märchen in drei Akten" with the intertextual imagery of the third prince, the struggle between good and evil, and seemingly direct references to the Bremer Stadtmusikanten and Rumpelstilzchen from fairy tale theory and fairy tale itself. His alteration of the lines in the Märchen corresponds perfectly to the popular practice of the Erzähler, who preserves the gist of the story and its underlying truth - even if, however, failing to transmit the exact details. ${ }^{6}$ Zuckmayer preserves the popular spirit by including the Märchen element in his Volksstück, a genre that tolerates his inclusion of every dramatical technique possible toward achieving the entertaining and contemporarily critical aims of the tradition it represents.

The character of Wilhelm Voigt is a representation of the archetypal fairy tale figure of Wilhelm Grimm's analysis. Zuckmayer gives indirect evidence of his dramaturgical objectives with respect to fabulous elements in Der Hauptmann von Köpenick in his essay upon "Die Brüder Grimm: Ein deutscher Beitrag zur Humanität." The hero of his drama, Voigt, is linked to monarchical power only through the uniform. Yet as the third in line to its inheritance - a factor 
reemphasized by Voigt's acquisition and employment of the uniform in the third act

- Voigt relates in poetic terms to the "third son" of Wilhelm Grimm's analysis:

Verschiedentlich wird die Geschichte von einem König erzählt, der drei Söhne hinterläßt und nicht weiß, welchem er Krone und Reich nach seinem Tode uiberlassen soll. Er macht daher eine Aufgabe, sei es nun etwas Schweres zu vollbringen, etwas Seltenes und Kostbares zu holen oder eine große Kunst zu erlemen. ${ }^{7}$

Engelsing-Malek is not far off when she states that Voigt "gleicht dem jüngsten und oft dümmsten Bruder im Märchen, dem es gelingt, den Zauber zu lösen. ${ }^{8}$ Under an interpretation linking Voigt to the "third son" described in the passage above, Zuckmayer instills fable with both historical and sociological meaning. Kaiser Wilhelm has abdicated, leaving only the uniform as symbol of Prussian rule and might. Von Schlettow has his uniform tailored to suit the Kaiser's demands, but loses it through an incapacity to fulfull his role in bourgeois society. Obermüller, the representative of the bourgeoisie, inherits the uniform for which he has grown too large. The third in line, Voigt, accomplishes "etwas Sonderbares und Kostbares" as attested by the Kaiser's laughing approval of the Gaunerstreich. Voigt corresponds to the third in line of Wilhelm Grimm's fairy tale analysis: he accomplishes his amazing feat to the pleasure of the royal patriarch.

As a social outcast and victim of repeated bureaucratic rejection, Voigt represents Grimm's third-in-line prince in yet other ways:

Der Dummling aber zieht in kindlichem Vertrauen aus, und wenn er sich ganz verlassen glaubt, hilft ihm eine höhere Macht und gibt ihm den Sieg über die andern. Ein ander Mal hat er weltliches Wissen hintangesetzt und nur die Sprache der Natur erlernt, darum wird er verstoßen, aber jene Erkenntnis hebt ihn bald über die andern. ${ }^{9}$

Voigt's command of the Berliner dialect and Lebensweisheit evinced throughout by his cutting wit clarify Voigt's identity as natural outsider to the system; they naturally oppose the artificial Beamtensprache and bureaucratic logic of the officials against 
whom he contends. But upon realizing the task of overcoming the forces of the authoritarian system that has held him down, Voigt magically assumes overbearing command of the Beamtensprache that has formerly been used to exclude and expell him. Voigt's naiveté and stubborn refusal to accept the unnatural complexity of the bureaucracy leave him abandoned by the system. At the moment when his rejection becomes absolute, the higher power of the uniform elevates Voigt to a position of temporary supremacy.

Like the third prince of fairy tale theory, Voigt excels in powers of mimesis and riddle solving. He is "aller List und Behendigkeit voll" and apes everyone. Voigt does an even better job of taking command of a situation than the Schutzmann who steps in at the end of the third scene to arrest Schlettow and the grenadier (30-31). He repeatedly parrots Knell's interrogative from the fourth scene ("haben Sie gedient?"), in order to intimidate his opponents within the system $(101,107,108)$. Like Grimm's third royal son, "Er allein kann die vorgelegten Rätsel lösen." 10 The twist is that in solving the riddle, Voigt himself falls victim to its powers. In the third scene he remarks to his comrade, Kalle: "Wie de aussiehst, so wirste anjesehen" (28). His observation fulfills the same function as the moral to a fable at the conclusion the third scene. Hauptmann von Schlettow, out of uniform, becomes powerless against the improprieties of a drunken grenadier, and Voigt reiterates, "Siehste Kalle - wat hab ick immer jesagt? Wie der Mensch aussieht, so wird er anjesehn" (30-31). Voigt's abilities of imitation lead him to command full military authority once in uniform. Yet upon discovering that his authority still cannot get him a passport, he solves the real riddle to the system - the fact that everyone is playing along in a masquerade of self-deception. 
Whether through a personal act of will or because of his rejection by the system, Voigt also fits the description of Grimm's "Däumling," who never develops beyond the stage of infancy. ${ }^{11}$ The bureaucracy withholds from Voigt the status of a grown man by denying him work and an official identity. In fact, the only person with whom Voigt is able to make himself understood is Liesken, the young boarder in his sister's home (twelfth scene). Even after confiscating the funds of the Rathaus in Köpenick and appearing to have effectively outgrown the system, Voigt renders the funds and himself back into the hands of the authorities. The Wilhelm Voigt of Zuckmayer's fairy tale fulfills the function of Wilhelm Grimm's fabulous third royal son through position, character and perception. Yet through a significant adherence to noble propriety, he renounces the monetary privileges of his act for an assurance of legitimation in his original role as member of the third estate.

The fabulous Voigt of Zuckmayer's drama becomes the representative of the subjective human spirit over and against the dehumanizing power of a purely objective bureaucracy. "Schon das Hauptthema, der Gehorsam der realen Welt gegenuiber der Kraft, der auf Gott vertrauenden Seele, entspricht den von den Briidern Grimm gesammelten Märchen.” Zuckmayer takes up the fabulous theme of a struggle between the powers of good and evil as well: "Der Held kämpft allein gegen das Böse, im Hauptmann von Köpenick gegen die anonyme und unbegreifliche Macht der Behörde." 12 Voigt cannot obtain work without a residence permit. And in the second scene, the Oberwachtmeister refuses to allow an unemployed ex-convict to register: “Einem stellungslosen Zuchthäusler können wir keine Aufenthaltserlaubnis geben” (16). In the role of Däumling, Voigt is like Hansel of Hansel and Gretel, who dissembles a withered finger with a splinter to outwit the witch; or the soldier who places the hole in his boot over a hole in the ground. so that the devil can never fill his 
boot with gold nor claim his soul. "Derart sind diese Märchen der Aufstand des kleinen Menschen gegen die mythischen Mächte, sie sind die Vernunft Däumlings gegen den Riesen." 13 Yet although Voigt's struggle brings him into continuous conflict with representatives of the bureaucratic apparatus symbolic of the fabulous element of evil, Zuckmayer takes care to let none of its representatives assume the demonic qualities reserved for the bureaucratic system itself.

The subtelty of Zuckmayer's humor extends to the liberality with which he cites excerpts from the fairy tales of the Brothers Grimm. He uses the transformed lines as a framing device for the text of Der Hauptmann von Köpenick. Zuckmayer exerpts the line preceding his drama from the tale of Rumpelstilzchen: " Nein', sagte der Zwerg, 'laßt uns vom Menschen reden! Etwas Lebendiges ist mir lieber als alle Schätze der Welt!" (3). Zuckmayer's only technical deviation lies in the replacement of the original "Lebendes" with "Lebendiges." 14 His alteration appears at first glance to be an insignificant error of transcription. ${ }^{15}$ But the cardinal distinction in the tale of Rumpelstilzchen is between an animate and inanimate object. In Der Hauptmann von Köpenick, it is between the activity versus inactivity of the living Voigt. There appears every reason to assume that Zuckmayer's liberality of translation was intentional.

Zuckmayer's epigrammatic twisting of roles in the quote from the Bremer Stadtmusikanten must be intentional as well. The meaning inherent in the transition corresponds too closely to the dramatic elements with which Zuckmayer surrounds it to be otherwise. The version in the Brothers Grimm reads " 'Ei was, du Rotkopf,' sagte der Esel, 'zieh lieber mit uns fort, wir gehen nach Bremen, etwas Besseres als den Tod findest du überall " (Märchen, I, 130). ${ }^{16}$ Midway through the dramatic action, "Komm mit" is the convocation Zuckmayer places in the mouth of the creature 
last in line of the original fairy tale (78). In this respect, the rooster becomes the symbol of the socially last in line of the Depression, reinforcing Voigt's representative role as a member of the third estate. The Bremer Stadtmusikanten is a tale of various creatures struggling against their cruel human masters. ${ }^{17}$ Zuckmayer repeats the Aufforderung of the twelfth scene with a quotation appended to the conclusion of his drama. His alteration is so subtle that his critics seem to have thus far regarded it as an insignificant detail attributable to poetic carelessness. ${ }^{18}$ But through the addition of a single letter to a verb in the singular, Zuckmayer shifts the direction of Voigt's rousing call to action from a single dramatic character to the plurality of his living audience. This time he quotes the line from the Bremer Stadtmusikanten as follows:

'Kommt mit', sagte der Hahn, 'etwas Besseres als den Tod werden wir überall finden!'

(Briider Grimm, Die Bremer Stadtmusikanten) (128)

The significance of Zuckmayer's shift in diction lies in the subtle message it imprints on the lines, since by changing them, Zuckmayer appropriates the lines to himself. Zuckmayer, the playwright, now assumes the role of the rooster as wakener - a role thematically represented by God and society within the Hauptmann von Köpenick text. 19 Zuckmayer's final linguistic alteration thematically underpins Voigt's postcoup realization that true happiness cannot be achieved in the gratification of his own needs alone. Through his transformation of the line from the Bremer Stadtmusikanten, Zuckmayer places the passively last-in-line creature of fairy tale into a rousingly active role by lending it voice.

The "Kommt mit" of the conclusion represents Voigt's final entry into society. It also suggests public cooperation toward the discovery of happiness ("etwas Besseres als den Tod") by peaceful means, thus reinforcing the significance of Voigt's surrender to the public authorities. The reversal of speaking roles between the Grimm 
and Zuckmayer versions corresponds quite nearly to the different attitudes voiced by Hoprecht and his brother-in-law, Voigt. Similar to the donkey of Grimm's tale, the stubborn Hoprecht attempts to persuade Voigt to follow the rules of the expulsion order commanded by the system (87-92). Voigt struts like a rooster into the action of the seventeenth scene, commanding a corps of soldiers to fall in line behind him (101). As in the reversal of the logic of ideology presented in his drama's title, Zuckmayer reverses the tag-along role of the rooster in the Bremer Stadtmusikanten, making him the leader of the band of oppressed animals by implication. The symbolic imagery of the rooster's role in rousing to wakefulness lends a further dimension to the transition. ${ }^{20}$ Zuckmayer's alteration of the line from Rumpelstilzchen reinforces the call to human awareness and activity inherent in his drama. His restructuring of the line from the Bremer Stadtmusikanten redirects an exhortation addressed to a single character and shifts it to the plurality of his audience.

Zuckmayer combines fairy tale elements with those of the Volksstück to establish a dramaturgical interconnection between stage, author and audience. "Zuckmayer's Märchenverständnis hat die romantische Poetik geprägt. Für die ist alle Poesie märchenhaft, das Märchen Grundlage der Poesie, das Volk selbst also der poetische Genius." Zuckmayer's work, "wie Märchen," strives to be "“Volks'stiick im eigentlichen Sinne, weil Ausdruck des Volksgeistes, oder besser: der Volksseele.”21 Zuckmayer viewed the actual Wilhelm Voigt "bei einer Mainzer Fastnacht" in 1910.22 His childhood memories of the popular folk-hero were directly linked to popular festival tradition as he seized upon Voigt's sensational Köpenickiade as the theme for his contribution to the Heidelberg festival. Voigt filled the gap Zuckmayer hoped to fill with a popularly traditional Eulenspiegel figure: "der arme Teufel, der - durch Not helle geworden - einer Zeit und einem Volk die Wahrheit exemplifiziert.”23 
Zuckmayer leaves his imprint as Märchenerzähler, or popular interpreter of myth, upon his drama. He alters the figure of the historical Voigt to correspond to his "Märchengedanke." $24 \mathrm{He}$ transforms the lines of the Brothers Grimm to add intertextual dimension to the elements of myth within his dramatic folk tale (see the paragraph above). Zuckmayer places himself in the role of intermediary between the spaces of historical fact, myth, dramatic event and audience.

The poetic bond between the Volksstück and its audience is an enduring tradition: "Das Volksstiick und Vorstadttheater lebte von Anfang an in der Spannung zwischen Unterhaltung und Kritik." The Volksstück directs its criticism at society through the establishment of a theatrical link with its audience: "Der Begriff Volksstïck, ursprünglich wohl österreichisch-süddeutscher Herkunft, meint den lebendigen, historisch-sozioökonomisch konkreten Bezug des Theaters auf Publikum und Gesellschaft in ihrem wechselseitigen Verhältnis."25 Zuckmayer, Anzengruber, Thoma, Kaiser, Horváth and Brecht transported the Volksstück concept into the modern theater. ${ }^{26}$ Zuckmayer serves the entertainment over the critical function of the genre in many of his Volksstïcke. Yet in Der fröhliche Weinberg and Der Hauptmann von Köpenick, his criticism of contemporary society elevates both to the true Volksstück level. ${ }^{27}$ Zuckmayer's dramatic tale of the Köpenickiade could alone, "als Persiflage des wilhelminischen Militarismus wirklich für sich in Anspruch nehmen, ein Volksstück zu sein." 28 The lasting popularity of Zuckmayer's "deutsches Märchen in drei Akten" shows not only its continuing ability to entertain. ${ }^{29}$ The struggle of an average citizen toward the attainment of societal identity against the depersonalizing forces of bureaucracy is as relevant today as it was in 1931. The Hauptmann von Köpenick's enduring themes continue to address the lasting societal issues still affecting its audience. ${ }^{30}$ 
The Hauptmann von Köpenick has been classified under various categories for just reasons. It incorporates a wide range of elements of many genres or types. Yet the one genre that truly defines its position in German theater is that of the Volksstück. It allows for an extensive variety of generic elements to be subsumed within it. ${ }^{31}$ The Volksstück exercised a liberating function upon the German stage with its return to popularity during the nineteen-twenties:

Die erneuerte Volksstiick-Form erlaubte die Verbindung heterogener Elemente; das Milieuhafte und Atmosphärische der lokalen Bindung steht neben zeitbezogener Sozialkritik, mildert diese oft; Situationskomik, humorvolle und rührende Züge, Sprachkomik bis zur Satire bringen in ihrer Abfolge bzw. im Ineinanderverschränktsein einen Bilderbogen hervor, dessen Stil- und Spielebenen die mimischtheatralischen wie sprachlich-wirklichkeitsbezogenen Elemente des volkstümlich gewordenen Stoffes ausschöpfen. ${ }^{32}$

The Volkstück was thus a vehicle for elements of Realism or Naturalism, Zeitstück and Neue Sachlichkeit. Zuckmayer employed the tolerantly inclusive potential of the Volksstück to the utmost by employing every generic element within its dramatic structure that would not conflict with its overall attitude of patient integration.

The Hauptmann von Köpenick's tolerant incorporation of wide-ranging elements allowed it to mirror the times. It stood in marked contrast, however, to the heated political tensions of 1931 , which it was largely able to overcome. ${ }^{33}$ Zuckmayer's drama also contradicted the growing popularity of radically ideological styles of dramatic presentation. It was outwardly antithetical to the Lehrstücke or Tendenzstücke that attempted to convince their audiences through open adherence to politically ideological themes. ${ }^{34}$ Violent threats from the right accompanied its opposition by Goebbels' radically ideological Angriff:

There were no riots in the theaters, although the Nazi press waxed rabid over the play, especially the Berlin Angriff. Referring to one scene in prison, that paper - edited by Goebbels - predicted that I would soon have the opportunity to become acquainted with a 
Prussian prison from the inside. I was even then threatened, in anticipation of of the coming seizure of power, with expatriation, exile, or simply the hangman. Defamatory letters arrived. I threw them into the waste paper basket and chose to believe the others, the letters of approbation and encouragement. ${ }^{35}$

The Hauptmann von Köpenick produced mildly violent repercussions from supporters of the reactionary cause of Goebbels and others. Yet it presented its political message in extremely moderate terms when compared to the general atmosphere of discontent in the streets. Zuckmayer's drama performed the contemporary-critical function of the Volksstück with a clarity that one can only attribute to its author's concerted attempt to avoid an openly polemical form of presentation.

Behind its politically objective outward aspect, however, Zuckmayer's drama contained a scathing attack against the spirit of militancy brewing in 1931:
All the anger, the hatred, the sense of outrage were directed against this 'government' which the rightists denounced as 'the Jews' republic' and the leftists as 'the capitalist state.' The emergency ordinances with which the administration tried to curb extremism from both directions achieved the opposite effect. Open warfare broke out between the Communists and the Nazis; hardly a night passed without bloody skirmishes with clubs and guns. But the most fateful development of all was the impoverishment of the lower middle class. ${ }^{36}$

Zuckmayer toned down the heated battle-zone atmosphere of Weimar reflected in the Hauptmann von Köpenick. The open stylistic form of the Volksstück rendered itself freely to historical interpretation: “Zugleich erhält die Komödienfabel die Potenz der Aktualisierbarkeit; das Geschehen ist auf ähnliche Fälle in der Geschichte uibertragbar." 37 The third-scene scuffle between Schlettow and the grenadier reflects the daily public street-fights of 1931 Germany in gentle miniature. It contrasts with the inability or unwillingness of Weimar government army officials to step in and halt the violence. In the Hauptmann von Köpenick, a military Schutzmann steps in to enforce law and order as soon as the fighting erupts (30-31). But despite the contrast 
with contemporary political tensions represented in its stylistic form, Zuckmayer's drama ranges its generic Volksstück elements in well-reasoned resistance to the greater historical trends behind the open violence of Weimar. By means of the Komödienfabel, Zuckmayer is able to transport the actuality of events of late Wilhelmine Germany into the late Weimar context. He calls attention to the enduring spirit of militarism of both periods with the inherent distinction that, in contrast to conditions under Weimar, the policing authorities of Wilhelmine Germany are still in position to control civil disruption.

The timelessness of the Köpenickiade fairy tale upon which Zuckmayer based his Volksstück allowed it to critically interact with the socio-political developments of its premiere, as was its author's intent. ${ }^{38}$ The new generation of creative talents proved more resistant to the turbulent period of the rise of the NSDAP than the older generation of authors working in the Volksstück genre:

es waren die Theaterstiicke von Bert Brecht und Carl Zuckmayer, die ihre Dauer und dichterische Lebenskraft aus der Erneuerung des Volksstuicks gewannen. Georg Kaiser und Carl Sternheim gehörten beide dem Jahrgang 1878 an; Zuckmayer ist 1896, Brecht 1898 geboren. Man kann dabei mit Hegel von der 'List der Idee' sprechen, die im Werke dieser beiden Dramatiker gerade die vitalen Energien des Volksstiucks heraufruft, um damit das Drama gegen die Tendenzen des 'Dritten Reichs' zu behaupten, das die Mobilisierung der 'volkhaften Kräfte von Blut und Boden' für sich selber in Anspruch nahm. 39

As a member of the new generation of German playwrights, Zuckmayer posed his Wilhelm Voigt as representative of the German people as symbolic rival to the gathering forces of the movement of National Socialism.

Zuckmayer lampoons the Blut und Boden myth of the NSDAP with Voigt's claim to Prussian blood-lines in the eighth, or "Zuchthaus" scene (53-58). Voigt demonstrates his field-marshaling talents in a disciplinary prison exercise. When the 
prison director inquires after the source of Voigt's military knowledge, Voigt replies: "Det hat 'n Preuße im Blut, Herr Direktor," and turning to the man at his rear, "In Gruppen rechts schwenkt - marsch! Grade - aus!! Ohne Tritt - marsch!" (57). Voigt's answer here is as if in response to the Prokurist Knell's dismissive statement regarding his lack of military service: "wennse gedient hätten, wär Ihnen das in Fleisch und Blut übergegangen" (33). Voigt makes ironic usage of Blut und Boden argumentation at the point where it most obviously fails: no-one is merely born a commander just as no-one is automatically born with German traits. ${ }^{40}$ In the final scene, Voigt reveals the true source of his military knowledge as he reflects upon his prison sentence: "Und in Zuchthaus Sonnenburg, da ham wa in den Freizeiten immer de Felddienstordnung zu lesen jekriegt, und det Exerzierreglement. Da hatt ick mir immer sehr für interessiert" (126). Zuckmayer exposes the perversity in purely authoritarian thinking through Voigt's conversation with his brother-in-law of the fourteenth scene. Between Voigt and his autochthonous claims to Boden or Heimat, the dehumanizing bureaucracy inserts itself as the prime obstacle:

VOIGT Mensch, ick häng an meine Heimat jenau wie du! Jenau wie jeder! Aber se sollen mir mal drin leben lassen, in de Heimat!! Denn könnt ick auch sterben für, wenn's sein muß! Wo is denn de Heimat, Mensch? In 'n Polizeibüro? Oder hier, ins Papier drinnen?! Ick seh ja gar keene Heimat mehr, vor lauter Bezirke!! (90)

One of the hidden contenders in the ideology of the NSDAP was the growing German population, upon which it based its demands for greater Lebensraum. Voigt's complaint is directed against the sort of local politics that excluded less desirable elements in the German population in exchange for the promise of future territories in which to settle them. It could easily be directed at the following passage from Mein Kampf: "Die Erwerbung von neuem Grund und Boden zur Ansiedelung [sic.] der überlaufenden Volkszahl besitzt unendlich viel Vorzüge, besonders wenn man nicht 
die Gegenwart, sondern die Zukunft ins Auge faßt." 41 The enduring militant spirit was again making its return into the open field of battle in 1931. Zuckmayer chose the Volksstück as the prefered medium to attack its reentry into the public sphere. He chose the Köpenickiade because it attacked the eternally recurring demon of aggressive militarism at its anti-societal and anti-humanitarian roots in nationalism.

Zuckmayer takes Wilhelm Voigt's outrageous political prank of 1906 and imbues it with fairy tale imagery in drafting a Volksstück to rival the Nazi myth of the unified cause of people and army. In shifting the responsibility for Voigt's predicament completely over to the system, Zuckmayer creates a conflict between good and evil in which Voigt represents the German people in their struggle against the military bureaucratic powers of evil. ${ }^{42}$ The National-Socialist ideology unites the people and military against the so-called "Schwätzer" of the German Parliament. ${ }^{43}$ Hitler describes the relationship between people and military in what effectively amounts to contractual terms of infinite obligation: "Was das deutsche Volk dem Heere verdankt, läßt sich kurz zusammenfassen in ein einziges Wort, nämlich, Alles." 44 Zuckmayer divides the elements of people and military into a fabulous conflict that more closely reflects reality. ${ }^{45}$ His Märchen becomes an ironic fable in the process. Its desperate Hauptfigur commits a miniature coupt d'état in demonstration of the fable's dystopian moral: "Kleider machen Leute." Zuckmayer's Voigt unveils the system as a blindly false representative of the German Volk, as an ignorant Leviathan whose full attention is captivated by strict adherence to its own self-imposed rules regarding the formality of appearance.

By entitling his drama "ein deutsches Märchen in drei Akten," Zuckmayer creates an interplay between fact and fiction that corresponds to a thematic undercurrent linking dramatic action to political reality. Voigt represents the fabulous 
third royal son of Wilhelm Grimm's theory, in which aspect he symbolizes the third estate ("der dritte Stand"). The German people, from the lower middle class on down, became dispossessed by the Great Depression beginning just a year and a half before the premiere of Zuckmayer's drama. Zuckmayer illustrates Voigt's struggle against an impersonal bureaucracy with fabulous imagery, through which he reflects the social reality of 1931 . The principal dramatic conflict was at that time highly pertinent to the Zeitumstände: the struggle of over six million unemployed to sustain their existence against forces that preferred to ignore their presence. ${ }^{46}$ Zuckmayer restructures the fairy tale lines placed at the beginning, middle and end of his drama, thus reinforcing the call to action already present in their content. His incitement to action binds Zuckmayer to his audience. The Hauptmann von Köpenick addresses itself to the spirit of the people in true Volksstück fashion. Zuckmayer utilizes the Volksstück possibility for the integration of varying dramatic genres and types to the utmost. The Hauptmann von Köpenick is a dramatically effective synthesis not only of Märchen and Volksstück. It formulates its dramatic conflict through an antithetical, additive and synthetic combination of the styles of Expressionism and Neue Sachlichkeit on many levels. ${ }^{47}$ Zuckmayer's comedy addresses itself to the increasingly modern themes of social identity and alienation with a plea for a peaceful solution. It still holds a good deal of the relevance to the Zeitumstände of today that it had upon its premiere on March 5, 1931. The Hauptmann von Köpenick's Volksstück ingredients brought its author into direct open conflict with the publisher of the Angriff and the author of Mein Kampf. Zuckmayer formulates his attack against Nazi ideology into an unmasking of the glaring contradiction inherent in the combination of Blut und Boden nationalism and military expansionist aims. He exposes the vicious circle ("Teufelskreis") created in a society dominated by military authority. A military 
functioning on its own logic systematically excludes the human being it is there to protect (Zuckmayer demonstrates proper military function through the action of the Schutzmann of the third scene). The animals' revolt of the Bremer Stadtmusikanten carries over as underlying theme into the Märchen Zuckmayer creates of the notorious Köpenickiade of 1906. By means of his extreme ingenuousness, Voigt is a comic exaggeration of the Dummling of Grimm's description. He not only apes those who surround him. He imitates fairy-tale as well. The animals' revolt and deception provide Voigt with the concepts for the execution of his coup. Zuckmayer transforms history into fable in an attempt to appeal to the German people's will to peace against the spectre of destruction looming on the contemporary German horizon. He directs his polemic against Nazi ideology by reversing the direction of argument taken by Nazi propagandists, who upon seizing absolute political control transformed the fable of the German people and nation into a political reality of disastrous consequences. 


\section{ENDNOTES}

${ }^{1}$ Carl Zuckmayer, A Part of Myself, trans. Richard and Clara Winston (New York: Harcour Brace Jovanovich, Inc., 1970) 311.

${ }^{2}$ Carl Zuckmayer, Als wär's ein Stück von mir: Horen der Freundschaft (Wien: S. Fischer Verlag, 1967) 438-39. Apart from the passage quoted directly above, the translation of the Winstons skips over these details (see directly above, note 1). The two other authors mentioned were René Schickele and Max Mell. What Price Glory appeared in the German cinema under the title Rivalen.

${ }^{3}$ Zuckmayer, Stück von Mir, 439. Part of Myself, 311. Zuckmayer claims that for Der blaue Engel, "the scenario and dialogue were entirely my own, while Friedrich Holländer wrote his unforgettable songs for it."

${ }^{4}$ Stück von Mir, 439.

5 Werner Frizen, Carl Zuckmayer: Der Hauptmann von Köpenick (München: Oldenbourg, 1988) 95 .

${ }^{6}$ Zuckmayer surely intended on the transformation of the lines as a technique for providing his text with greater meaning. With respect to the Märchentheorie of the Brothers Grimm, Zuckmayer may have actually quoted the lines freely. Yet it seems likelier that he purposefully altered them to fit the context of his tale in order to produce the humanly direct effect of the "Märchenerzähler," who holds tradition in his, or her, memory.

7Wilhelm Grimm in Carl Zuckmayer, "Die Brüder Grimm: Ein deutscher Beitrag zur Humanität," Carl Zuckmayer. Ein Jahrbuch , ed. Barbara Glauert (Frankfurt am Main: S. Fischer Verlag GmbH, 1978) 279.

8Ingeborg Engelsing-Malek, »Amor Fati« in Zuckmayers Dramen (Berkeley and Los Angeles: University of California Press, 1960) 49-50.

9Wilhelm Grimm, in Zuckmayer, "Die Brüder Grimm," 279.

10Wilhelm Grimm in Zuckmayer, "Die Brider Grimm," 279-80. The passage cited appears in Zuckmayer as follows: "Der Dummling ist der Verachtete, Geringe, der Kleine, und nur von Riesen aufgesäugt wird er stark. So nähert er sich dem Däumling, der bei Geburt nur daumengroß ist und nicht weiterwächst. Bei ihm aber ist alles in Klugheit ausgeschlagen, er ist aller List und Behendigkeit voll ... Jedermann äfft er und zeigt eine Lust an gutmütiger Neckerei, manchmal ist er das kluge Schneiderlein, das mit seinem feinen und schnellen Verstand die Riesen schreckt, die Ungeheuer tötet und die Königstochter erwirbt. Er allein kann die vorgelegten Rätsel lösen." 
11Wilhelm Grimm in Zuckmayer, "Die Brüder Grimm," 279. See note 10 above. Voigt's transition to adulthood is blocked by his inability to find acceptance within the system.

12Engelsing-Malek, 49.

${ }^{13}$ Ernst Bloch, Erbschaft dieser Zeit: Erweiterte Ausgabe (Frankfurt am Main: Suhrkamp Verlag, 1962) 168-69.

${ }^{14}$ Engelsing-Malek, 49, n. 4, provides the original: "Nach den Märchen der Brüder Grimm heißt das Zitat: “. . . aber das Männchen sprach: 'Nein, etwas Lebendes ist mir lieber als alle Schätze der Welt' (I, 252)."

15 Engelsing-Malek, 49, n. 5, speculates that, "Die Tatsache, daß Zuckmayer frei zitiert, kann vielleicht so gedeutet werden, daß ihm das Wesentliche der Märchen gegenwärtig war, ohne daß er in philologischer Sorgsamkeit die Bücher benutzte."

16Engelsing-Malek, 49, n. 5.

17 Jacob and Wilhelm Grimm, "The Bremen Town Band," Jacob and Wilhelm Grimm: Selected Tales, trans. Gilbert McKay and Philip Schofield (Harmondsworth: Penguin Books Ltd., 1982) 370-73.

${ }^{18}$ So Engelsing-Malek, 49, n. 5. Cited in note 15 above.

${ }^{19}$ See note 20 directly below.

20 The transferal of the voice from the donkey as symbol of obedience to the rooster as wakener underplays Voigt's decisive transition from acceptance of the powers of authority to resitstance. Voigt describes the vision that inspires him: "Und denn, denn stehste vor Gott dem Vater, stehste, der allens jeweckt hat, stehste ..." (91); behind the scenes, God plays the fabulous function of the rooster in rousing Voigt to wakefulness. Zuckmayer puts society in the same role a few lines above when Voigt declares, "Nee, mir hamse zu lang jepufft, mir hamse nu wachjekriegt, de jibt's keen Pennen mehr, ick will det nu janz jenau wissen!!" (91).

21 Frizen, 97.

22 Stück von mir, 440.

${ }^{23}$ Stück von mir, 440.

${ }^{24}$ Stück von mir, 440. 
25Jürgen Hein, "Das Volksstück: Entwicklung und Tendenzen" Theater und Gesellschaft: Das Volksstück im 19. und 20. Jahrhundert (Duisseldorf: Bertelsmann Universitätsverlag, 1973) 10.

26Hein, "Das Volksstück," 21.

27 The power of the Der fröhliche Weinberg's social criticism was in fact so forceful that it caused riots all over Germany. It was also so popular, that it was played over 500 times during two years at the "Lessing-Theater" in Berlin. Thomas Ayck, Carl Zuckmayer in Selbstzeugnissen und Bilddokumenten (Reinbeck bei Hamburg: Rowolt Taschenbuch Verlag, 1977) 54.

28 Marianne Kesting, Panorama des zeitgenössischen Theaters: 58 literarische Porträts: Revidierte und erweiterte Neuausgabe (München: R. Piper Verlag, 1969) 279.

${ }^{29}$ The latest staging of the Hauptmann von Köpenick achieved national acclaim in Germany with Harald Juhnke in the leading role. Doubting the effectiveness of director Katarina Thalbach's ignorance of the element of guiltlessness with respect to Voigt, Franz Wille sarcastically writes: "Und wenn es doch gelänge? Dann wäre Zuckmayer's Stück endgültig als Sozialkitsch entlarvt und der Hauptmann von Köpenick als Held der Unterhaltungsindustrie wiedergeboren." Franz Wille, “Zirkus Juhnke gibt nie auf," Der Spiegel 5 (29. 1. 96): 171-72.

30 Günther Fleckenstein gives extensive treatment to the element of timelessness in Zuckmayer's dramas in "Zuckmayer überzeitlich: Arbeit an seinem dramatischen Werk," Exil und Rückkehr: Emigration und Heimkehr: Ludwig Berger, Rudolf Frank, Anna Seghers und Carl Zuckmayer, Anton Maria Keim (Mainz: Verlag H. Schmidt, 1986) 159-70.

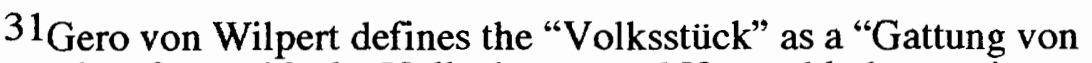
Bühnenstiucken für städtische Volkstheater und Vorstadtbühnen mit e. aus dem Volksleben entnommenen Handlung in volkstümlich schlichter, leichtverständlicher Form, die jedoch durch Einlagen von Musik, Gesang und Tanz sowie Anwendung von Effekten, Sentimentalitäten u. ä. niederen Elementen dem Geschmack des Großstadtpublikums entgegenkommt, ohne den oft ernsten und z. T. selbst tragischen Grundton zu verlieren." Gero von Wilpert, Sachwörterbuch der Literatur (Stuttgart: Alfred Kröner Verlag, 1964) 770-71. The Hauptmann von Köpenick meets Wilpert's definition in all respects: Zuckmayer composed it for the Heidelberger Festspiele and took a popular event as theme. Its form is "volkstümlich" and outwardly simple. It commences with military music. Knell sings a petit-bourgeois patriarchal ditty in the fourth scene. Clad in uniform, Augusta Wormser dances in the adjacent Festsaal of the thirteenth scene. Alfred Kerr criticized the twelfth scene for its sentimentality, which along with Voigt's inability to solve the problem of his fate, serves to preserve the fundamentally tragic atmosphere upon which the Hauptmann von Köpenick's plot builds. 
32Jürgen Hein, "Zuckmayer, Der Hauptmann von Köpenick," Die Deutsche Komödie vom Mittelalter bis zur Gegenwart, ed. Walther Hinck (Düsseldorf: August Bagel Verlag, 1977) 270.

33"The effect of The Captain of Köpenick was deeper and more lasting than that of The Merry Vineyard. Friend and foe alike understood the play as the political act it was meant to be. And so far my friends, at least in that part of the population who went to the thater at all, or who read plays, were still in the majority. The very fact that here too the 'other side,' above all the military, was not simply castigated but represented with an attempt at justice, lent a special force to the play and its ideas, without the distrust and nasty aftertaste that a one-sided view, or propaganda, always inspires." A Part of Myself, 315. The original is quoted in note 5 on page 51.

${ }^{34}$ The attitude of general tolerance does indeed represent an ideology as well. It is the ideology of the Liberal Democrat or "Stadtbuirger" in general terms, as reflected in Zuckmayer's open avowal of the "political act" (Politikum) Zuckmayer meant it to be. See above, page 65 (note 33).

\section{A Part of Myself, 315.}

36 A Part of Myself, 316.

37Hein, “Zuckmayer, Der Hauptmann von Köpenick," 270.

38 On choosing the theme of Wilhelm Voigt's assault on the Rathaus in Köpenick, Zuckmayer writes: "Denn wenn auch die Geschichte mehr als zwanzig Jahre zuruicklag, so war sie gerade in diesem Augenblick, im Jahre 1930, in dem die Nationalsozialisten als zweitstärkste Partei in den Reichstag einzogen und die Nation in einen neuen Uniform-Taumel versetzten, wieder ein Spiegelbild, ein EulenspiegelBild des Unfugs und der Gefahren, die in Deutschland heranwuchsen - aber auch der Hoffnung, sie wie der umgetriebene Schuster durch Mutterwitz und menschliche Einsicht zu überwinden." Stück von mir, 440.

${ }^{39}$ Martin Greiner, "Carl Zuckmayer als Volksdichter," Theater und Gesellschaft: Das Volksstück im 19. und 20. Jahrhundert, ed. Jürgen Hein (Düsseldorf: Bertelsmann Universitätsverlag, 1973) 161.

${ }^{40}$ Adolf Hitler gives expression to his racially exclusive and antihumanitarian ideas of culture in such passages as the following from Mein Kampf: "Selbst in alldeutschen Kreisen konnte man damals die Meinung hören, daß dem österreichischen Deutschtum unter fördernder Mithilfe der Regierung sehr wohl eine Germanisation des österreichischen Slawentums gelingen könnte, wobei man sich nicht im geringsten dariber klar wurde, daß Germanisation nur am Boden vorgenommen werden kann und niemals an Menschen." Mein Kampf (München: Zentralverlag der NSDAP, 1941) 428.

$41_{\text {Hitler, } 151 .}$ 
42Hitler's equation of military service with societal worth, authenticity and honesty openly attacks the activities of Parliamentarians. He returns to the context of the First World War in order make the veracity of his argument more vivid to the emotions: "Ich war damals Soldat und wollte nicht politisieren. Es war hierzu auch wirklich nicht die Zeit. Ich hege heute noch die Überzeugung, daß der letzte Fuhrknecht dem Vaterlande noch immer mehr an wertvollen Diensten geleistet hat als selbst der erste, sagen wir 'Parlamentarier'. Ich haßte diese Schwätzer niemals mehr als gerade in der Zeit, da jeder wahrhaftige Kerl, der etwas zu sagen hatte, dies dem Feinde in das Gesicht schrie oder sonst zweckmäßig sein Mundwerk zu Hause ließ und schweigend irgendwo seine Pflicht tat. Ja, ich haßte damals alle diese 'Politiker', und wäre es auf mich angekommen, so würde sofort ein parlamentarisches Schipperbataillon gebildet worden sein; dann hätten sie unter sich nach Herzenslust und Bedürfnis zu schwätzen vermocht, ohne die anständige und ehrliche Menschheit zu ärgern oder gar zu schädigen." Adolf Hitler, Mein Kampf (München:

Zentralverlag der NSDAP, 1941) 182.

${ }^{43}$ Hitler, 306.

${ }^{44}$ Hitler, 507.

45 For Zuckmayer's fairy tale portrayal of the conflict between good and evil, see above, page 57 .

46Under the Brüning government, "schwoll die Arbeitslosenzahl im Winter 1931 auf sechs bis sieben Millionen an." Ayck, 89. An article had appeared in Die Welt am Montag on 6 October 1930 entitled "Woher kommen Hitlers $61_{1 / 2}$ Millionen Stimmen?" It describes the effects of the Great Depression on the election results of September 20 of the same year: "Von den drei Millionen Erwebslosen hat nur ein verschwindend geringer Prozentsatz Hitler seine Stimme gegeben. Diese drei Millionen stellen vielmehr das Gros der kommunistischen Wähler dar. Wenn die KPD von 55 auf 77 Mandate gestiegen ist, so ist das die automatische Ruickwirkung der steigenden Arbeitslosigkeit. ... . Die Hitlerwähler setzen sich aus zwei Kategorien zusammen: einer kleinen Minderheit von Nationalsozialisten, die auf das Hakenkreuz eingeschworen sind, und einer riesigen Mehrheit von Mitläufern, d. h. bei keiner anderen ist das Mißverhältnis zwischen Stammkunden und Laufkunden ebenso groß." Quoted in Heinrich Bennecke, Wirtschafliche Depression und politischer

Radikalismus: 1918-1938 (München und Wien: Günter Olzog Verlag, 1970) 345.

${ }^{47}$ See below, pages $59-68$, and notes. 


\section{EXPRESSIONISMUS KONTRA NEUE SACHLICHKEIT}

Zuckmayer's rejection of ideological expression in art coincides closely with the stylistic features of the Neue Sachlichkeit movement. The main period of the Neue Sachlichkeit stretches from 1925 to 1929: "Die Zeit vom Ende der Inflation bis zum Tod Stresemanns war die eigentliche Phase der Neuen Sachlichkeit, auch wenn ihre Anfänge weiter zurïckreichen und sie nach 1929 nicht völlig verschwunden war." 1 Elements of the movement still find strong representation in Der Hauptmann von Köpenick. Among these is certainly the possibility it provides for reaching a wide audience. Zuckmayer's talent for filling the stage with rich visual imagery finds a parallel in the fact that the Neue Sachlichkeit has "als Epochenbezeichnung, allenfalls in der Kunstgeschichte, aber nie in der Literaturgeschichte durchsetzen können."2 Zuckmayer incorporates the elemental contrast within the movements of Expressionism and the Neue Sachlichkeit by employing both to stylistically accentuate Voigt's subjective conflict with the sachlich forces of Prussian bureaucracy. Critics have always contrasted the Neue Sachlichkeit, as a concept, with the Expressionist movement, in this way enabling them to elaborate upon its distinguishing features. "Hier wurde jeweils dann deutlich, in welchem Maße der einzelne Kritiker geneigt ist, die Neue Sachlichkeit positiv als 'neue,' eigenständige oder gar auf den Naturalismus zurückgreifende Kunstrichtung zu werten." 3 Der Hauptmann von Köpenick presents its characters with natural accents and behaviors fully in keeping with the Naturalistic emphases upon temps and milieu. ${ }^{4}$ But at the same time, Zuckmayer delineates the contrast between Neue Sachlichkeit and Expressionism by including both as stylistic and thematic elements of contrast in the Hauptmann von Köpenick. ${ }^{5}$ Zuckmayer uses the methodology of the Neue Sachlichkeit to form the setting against which Voigt's subjective predicament rises to a position of absolute opposition. Voigt wages his 
battle against the Prussian bureaucracy to settle his own account. The ideology presented in Zuckmayer's neu-sachlich tale of the Hauptmann von Köpenick is that of the individual against the powers of political absolutism.

Because of the expressed objectivity of its style, the Neue Sachlichkeit, "kann an keiner politischen Gruppierung festgemacht werden, vielmehr vereinigte sie zunächst alle Gruppierungen unter sich." ${ }^{6}$ Herbert Jhering's reception of the premiere of the Hauptmann von Köpenick both praises its author for not allowing his drama to become a "starres Tendenzstück," but criticizes him on the same grounds for failing to offer a clear "Weltanschauung" to his audience: "Er lenkt nicht den Geist des Zuschauers dahin, von wo aus er betrachten soll. So kann der eine den Militärschwank, der andere eine leichte soziale Anklage, der dritte die Satire sehen."7 Whereas the Volksstück allows for the unity of separate dramatic elements within an inclusive genre, the Neue Sachlichkeit appeals to a broad spectrum of the populace through its - at least apparent - lack of tendentiousness.

Through his treatment and application of objects of the stage, characters and dramatic techniques within the plot, Zuckmayer conceals the subjective elements of Expressionism within a neu-sachlich shell in order to heighten the dramatic conflict of the Hauptmann von Köpenick. The result remains a lasting symbolic reminder of the prevailing attitude of indifference to the underlying spirit of societal discontent at the time of its premiere on March 5, 1931. Hauptmann von Schlettow represents the aristocracy. Once he lays down his symbol of military authority, he becomes powerless to check the social improprieties of a drunken grenadier (30-31). Bürgermeister Obermüller is the political representative of the republican bourgeoisie. $\mathrm{He}$ is incapable of preventing the forces of uniformed authority from marching in and placing him and his governmental office under a state of military occupation, even 
when that authority is based purely on appearance (nineteenth scene). Voigt's plight represents the tragedy of the lower classes. Stuck between a militarily hierarchical system of justice and an economy paying obedience to the same order, Voigt represents the members of German society disenfranchised by the calamity of the Great Depression. Through the technique of Neue Sachlichkeit, Zuckmayer's Hauptmann von Köpenick subsumes the feelings of societal discontent affecting all political levels of Weimar Germany within his plot.

Zuckmayer uses a contrast of theatrical objects to symbolically divide the inwardly directed Expressionist viewpoint from the objective vision of the Neue Sachlichkeit. In "Zwischen Expressionismus und Faschismus," Reinhold Grimm chooses Zuckmayer's Hauptmann von Köpenick and Franz Werfel's Die Hose as representative of the distinction between Neue Sachlichkeit and Expressionism. He opposes the "deutlich enthüllende Funktion" of the mirror at the end of Zuckmayer's play, to the "verweisende Funktion" of Werfel's mirror. Werfel's mirror is supposed to, "wie es ausdrücklich heißt, eine 'höhere Realität bedeuten'." Werfel's mirror is a flatly lit "geheimnisvolle Spiegelfläche" that transforms at a touch into a giant window. 8 The subjective function of Werfel's mirror in Grimm's comparison corresponds closely to the function of the window in the twelfth scene of the Hauptmann von Köpenick. Here Liesken begs Voigt to come back and turn the light on: "Es wird ja schon duster draußen - un denn wird det Fenster so blank, so weiß wie'n Auge -" (77). In connection with the preceding conversation between Voigt and Liesken over their planned trip to the Carpathians ("iiber de Wolken"), the window reveals to Liesken a glimpse of the beyond, of her impending death. The metaphor of the photographer describes the Expressionist's method in relation to a similar object of vision: "Der Expressionist dreht die Kamera um und richtet die Linse 
auf sich selbst, nicht auf die Gegenstände."9 The blank window is Liesken's inward projection. The mirror in which Voigt finally views himself in Hauptmann attire directs his attention to the objective world of appearances made the object of his cunning Staatsstreich. The function of the window in Zuckmayer's drama serves as an Expressionistic contrast to the mirror of the closing scene, in which it serves to return Voigt to the sachlich world in which he has made himself the principal dupe of his own fantastic imagination.

Zuckmayer places a scene straight out of Expressionism at the center of a work widely held to be representative of the Neue Sachlichkeit movement. Apart from the transformation of certain qualities in the figure of Voigt and the events surrounding the Köpenickiade, Zuckmayer's close adherence to "Sachlichkeit, dokumentarische Genauigkeit und Wissenschaftlichkeit" of presentation certainly warrants the classification. But at the approximate center of the action he places a scene that, in marked contrast to his praise of the drama's performance as a whole, Alfred Kerr deplores as an unfortunate confusion of "dichterisch" and "sentimental." "Das kranke Mädchen wirkt furchtbar," he adds, ${ }^{10}$ and possibly because he sees therein traces of a reversion to the Expressionist literary genre for which Zuckmayer had no recognized talent. The Neue Sachlichkeit developed as an antithesis to the style of Expressionism: "Die Betonung des Gebrauchwertes der Literatur habe notwendigerweise das Bemühen um einen 'exakten Stil' zur Folge, der in Ablehnung der expressionistischen Hypertrophien 'unpathetisch, unsentimental, schmucklos und knapp' sein soll." 11 In the twelfth scene of his drama, Zuckmayer breaks with the rigidity of an otherwise sachlich presentation by introducing a scene filled with pathos and sentiment. The voices of the unseen singers reinforce the mood as they sing their "larmoyantes Lied," and the ailing Liesken is at first unseen but for her hand, which Voigt holds in his own 
(73). Along with the Expressionistic effect of the empty window noted above, the scene works as an interlude to the dramatic tension created by the "knapp," tightaction neu-sachlich scenes preceding and following it. By means of the antithetical technical contrast inherent in the Neue Sachlichkeit and Expressionism, the twelfth scene reemphasizes the internalization of dramatic tension occurring in the character of Voigt.

The twelfth scene of the Hauptmann von Köpenick is the subjective soul of the drama through which the central dramatic conflict between the subjective will of Voigt and the objective bureaucracy enters the realm of objective action. Voigt's divine vision is subjective to the extreme - a factor reinforced by its exclusion from the dramatic action. Zuckmayer introduces Voigt's vision into the action through the account Voigt gives to Hoprecht in the fourteenth scene: "De innere Stimme. Da hatse gesprochen, du, und da is alles totenstill jeworden in de Welt, und da hab ick's vernommen ..." (91). Zuckmayer maintains the Expressionistic character in Voigt's subjective revelation by presenting it realistically, in the natural dialect typical of the Neue Sachlichkeit. Voigt's will is fully subjective throughout. But the art of Expressionism sets "das Ich absolut, fordert den reinen Ausschrei."12 Voigt's will and vision are Expressionistic elements of the Hauptmann von Köpenick that begin to surface in the Expressionistic twelfth scene. The Expressionistic "Ich" achieves absolute dimensions in conflict with the absolute of the military bureaucracy. Expressionism provides the technical means through which the subjective element may be brought to a peak in conflict with its objective, neu-sachlich antithesis:

In neue und fremde Formen gewiesen, ist der Expressionismus erklärter Kampf. Alle uiberkommenen Formen, die er durchtobt, werden zu Reibungsflächen, an denen er sich zur Fackelglut entflammt. Kräfte ausschleudernd gegen ungezählte Widerstände, findet er nie Richtung ins Selbst, richtet das Selbst wider die Welt. 13 
Expressionism lays the ground for Voigt's seizure of absolute control in his conflict with the objective powers of military absolutism.

Der Hauptmann von Köpenick represents the movement of the Neue Sachlichkeit by inclusion in a plot that hinges on Expressionistic revelation. But because "der Expressionismus verabsolutiere das Subjekt, die Neue Sachlichkeit das Objekt," the title of Zuckmayer's comedy is "gewissermassen vertauscht." Thus, in Der Hauptmann von Köpenick, "wo der Mensch den Namen liefert, herrscht ausgerechnet die Sache." Zuckmayer's comedy, then, "müßte eigentlich Die Uniform heißen."14 Zuckmayer's elevation of an object to the role of leading figure in his drama shows his ability to use the objectifying principle of Neue Sachlichkeit through which to draw a more striking contrast with the humanly subjective element represented by his other main character, Wilhelm Voigt.

Neue Sachlichkeit defines the indifferent attitude of the authorities to internal developments that would soon be the means to their overthrow. In the opinion of its critics, Neue Sachlichkeit was, as a movement, very much a creature of its time. Type and genre correspond to a remarkable degree with regard to literary definitions of the Neue Sachlichkeit movement:

Fast immer aber kam bei diesem Vergleich der Neuen Sachlichkeit doch schon unversehens die Bedeutung eines Epochenbegriffs zu, so daß man einen wesentlichen Unterschied in der Anwendbarkeit beider Begriffe nicht genügend beachtete: die Tatsache nämlich, daß in der Literatur der zwanziger Jahre stilkuinstlerische Intentionen und politische Überzeugungen einerseits gänzlich unabhängig voneinander operieren konnten, andererseits sich aber in einer Vielzahl von Möglichkeiten verbanden, ohne daß das eine oder andere notwendigerweise von dem praktisch-politischen Engagement des Autors als Staatsbürger oder den literar-theoretischen Einsichten determiniert worden wäre. ${ }^{15}$

Neue Sachlichkeit represents an attempt at reaching objectivity of representation by distancing artistic intention from political opinion. "An die Stelle des visionären 
Dichters tritt der geistige Arbeiter, an die des Genies der Könner und Handwerker, der zum 'Beauftragten des Objekts' wird, ohne eigenen Standpunkt und ohne Tendenz." 16 The poet of the Neue Sachlichkeit is a dispassionate observer who constantly maintains his distance from his subject. ${ }^{17}$ Zuckmayer's Hauptmann von Köpenick shares a great deal with the Neue Sachlichkeit movement in its outward stylistic aspect.

Many historians still blame Germany's return to authoritarianism on the nonpolitical masses. But, if anything, the attitude of political indifference at the top was even greater. After appointing Heinrich Brüning to the position of Chancellor in 1930, Hindenburg allowed him to rule increasingly by decree under Article 48 of the constitution. ${ }^{18} \mathrm{He}$ thus avoided the complications of working with a Reichstag torn by political dissent. In a case before the Reichsgericht involving the dispersal of NSDAP literature by three lieutenants amongst members of a Reichswehr garrison in Ulm, Hitler was called to testify for the defense. After Hitler's testimony of September 25, 1930 denied involvement in plans for a coup d'état, the Reich Minister of the Interior, Zweigert, claimed he had documents that would prove the contrary. The court refused to see them. As reported in the findings of the court: "The Senate refused to examine evidence concerning the matter, since the question had no decisive bearing on the passing of judgment in the case." 19 In deciding the question of guilt in any given case, the German courts were often led to consider the political intentions of the defendants. In the Ulm affair, the three accused officers were all convicted, while the court ignored Hitler's contradictiory testimony:

'The fact that the National-Socialists' plan for a coup only existed in the minds of the accused did not affect the factual nature of their offence.' This point of view can be explained by the Reichsgericht's constant application of the 'subjective theory.' 'Subjective' traitors 
were found guilty. Hitler, who respected the law and was objective, left the court in triumph. ${ }^{20}$

Both the Reichwehr and the German judiciary hid their conservative politics behind a politically non-biased front. The judicial magistrates "considered themselves members of an exclusive caste endowed with many priveleges. Their pretence of administering a justice free from and uncontaminated by any political influence was as invalid as the Reichswehr's claim to be non-political." 21 Not only does Neue Sachlichkeit provide the ideal means for portraying the purely objective bureacratic environment in which Zuckmayer's Voigt is treated as a mere object, its style of presentation most accurately describes the prevailing mood of the German political authorities on the eve of Hitler's rise to power.

In Als wär's ein Stück von mir, Zuckmayer describes the general apolitical sentiment that the forces of reaction fed on in Germany during the early thirties - a tendency he neither excuses nor absolutely condemns:

War auch die Nazibewegung in ihren Anfängen von üblen, rachsüchtigen, nichts als machtlüsternen Elementen getragen, so wäre es völlig falsch, ungerecht, abwegig, die große Menge von Deutschen, die Anfang der dreißiger Jahre dem Nationalsozialismus zuströmten, in Bausch und Bogen zu verdammen.

Denn jetzt kamen zu den Hoffnungslosen die Hoffnungsvollen, die 'Idealisten', die Gläubigen, die sich wunschhaft unter dieser angeblich elementaren 'Volksbewegung' (in Wahrheit war sie raffiniert aufgezogen) etwas Anständiges, Ethisch-Hochwertiges, Positives vorstellten, und deren wesentlicher Fehler darin bestand, daß sie unpolitisch waren. Unpolitisch, wie das Volk von 1914 in den Krieg gegangen war - politisch unvorbereitet, wie es vom Zusammenbruch und von der Revolution uiberrascht wurde, zu politischem Denken nicht erzogen und nicht gewillt - , so verfiel ein großer Teil der Deutschen der Scharlatanerie und der Gewaltherrschaft, nur allzu gern bereit, sich unter der 'nationalen Erhebung' eine echte und wahre Erneuerung, auch im sittlichen Bereich, die Abkehr von Parteienhader, den sozialen Ausgleich, die Rückkehr zu sauberen, festen Gesellschaft- und Lebensformen zu erträumen. 22 
The NSDAP's ranks swelled with bands of Mitläufer. Their political indifference ignored a sachlich appraisal of the situation and underlying sentiments of misgiving in favor of pasting their hopes on a set of fantastic and unfulfillable promises.

Sachlichkeit can be described as the power of objective criticism. It can also describe unquestioning conformity to a set of preexisting rules. Zuckmayer used a technique combining the two-fold signification of Sachlichkeit in technical contrast to his subjective Expressionist method. His critically objective method of presentation most clearly demonstrates Voigt's subjective battle against forces whose sachlich pursuance of bureaucratic protocol dipassionately denies him the right to existence. Upon Hitler's rise to power, the general populace was perhaps best represented by people like Schlettow, Obermüller or Hoprecht: ready to repress personal sentiment to relinquish command, authority or the promise of promotion with classicly German pro forma adherence to an objectively formulated set of rules.

Zuckmayer incorporated the techniques of the Neue Sachlichkeit and Expressionism into his Hauptmann von Köpenick in order to intensify the dramatic conflict between Voigt and the forces of Prussian bureaucracy. The window of the twelfth scene is functionally important only as it appears to Liesken - as a purely subjective point of reference in the style of Expressionism. The mirror appearing at the dramatic conclusion appears like the uniform as an unmediated referent, as an object serving the dramatic functions of the Neue Sachlichkeit as described by the literary critic, Reinhold Grimm (see above, page 78). The mirror and uniform operate within the drama just as they would in the actual realm beyond the stage. Zuckmayer elevates the uniform to the level of Hauptfigur in playful exaggeration of the emphasis layed upon the "Sache" by the Neue Sachlichkeit. But as outward symbol of the objectively insoluble bureaucratic circumstances that hold him prisoner, the uniform 
also serves to heighten the subjective dilemma of isolation and exclusion facing Voigt. The uniform is not only an eternally reappearing ubiquitous prop endowed with its own plot-line of descent and Aufstieg. Once in his possession, it carries potent meaning as an externalization of the subjective will to freedom brewing in Voigt. It is the means by which he liberates himself from his externally indifferent circumstances. The techniques of Expressionism and Neue Sachlichkeit heighten the dramatic conflict through the inherent contradiction manifest in their mutual opposition to eachother. The unity of Voigt and the uniform represents a synthesis of the subject with the objective symbol of the forces of his contention. Zuckmayer uses the method of Neue Sachlichkeit to reflect the politically dispassionate mood dominating his period. Yet he maintains the subjectively Expressionistic stylistic element alive behind the Neue Sachlichkeit façade to represent the dormant feelings, desires and aggressions suddenly jolted into wakefulness by the severity of the Great Depression - the brewing spirit of social discontent regarded with too little interest by those within the system for political disaster to be averted. 


\section{ENDNOTES}

${ }^{1}$ In Jürgen Heizmann, Joseph Roth und die Ästhetik der Neuen Sachlichkeit (Heidelberg: Mattes Verlag GmbH, 1990) 17-18.

2Heizmann, 16.

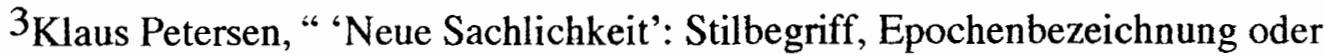
Gruppenphänomen?” Deutsche Vierteljahresschrift 56 (1982): 471.

${ }^{4}$ Zuckmayer merely touches upon the Naturalist's ingredient of rasse, eliminating it nearly completely as a determining factor in Voigt's character to meet other thematic objectives. Voigt claims to have Prussian blood in him (57).

5 Zuckmayer also uses neu-sachlich and Expressionistic elements to augment eachother, as in his synthetic application of both styles in the twelfth scene toward a heightening of the sentimentalizing effect.

6Jürgen Heizmann, 26.

${ }^{7}$ Herbert Jhering, Berliner Börsen-Courier 6 Mar. 1931: n.p., in Günther Ruihle, Theater für die Republik im Spiegel der Kritik, vol. 2 1926-1933 (Frankfurt am Main: S. Fischer Verlag, 1967)1078.

8Reinhold Grimm, "Zwischen Expressionismus und Faschismus," Nach dem Naturalismus: Essays zur modernen Dramtik (Frankfurt am Main: Athenäum Verlag, 1978) 55.

9Jürgen Heizmann, 19.

10Alfred Kerr, "Umbesetzung: Adalbert in Köpenick," Berliner Tageblatt 2 June 1931: n.p., in Günther Rühle, Theater für die Republik im Spiegel der Kritik (Frankfurt am Main: S. Fischer Verlag, 1988) 1085.

${ }^{11}$ Karl Prümm, "Neue Sachlichkeit: Anmerkungen zum Gebrauch des Begriffs in neueren literaturwissenschaftlichen Publikationen," Zeitschrift für Philologie 91 (1972): 608.

12Theodor W. Adorno, Gesammelte Schriften, vol. 2, ed. Rolf Tiedemann (Frankfurt am Main: Suhrkamp Verlag, 1974) 609.

13 Adorno, 609.

14 Grimm, 55-56. 
15 See Petersen, 471-72.

16 Jürgen Heizmann, 20.

17 Jürgen Heizmann, 20. "Er ist ein leidenschaftsloser Beobachter, der immer die Distanz zu seinem Sujet wahrt."

18 Brïning acted on orders from Hindenburg in dissolving the Reichstag on July 18, 1930. Helmut Heiber, The Weimar Republic, trans. W.E. Yuill (Oxford, U.K. and Cambridge, U.S.A.: Blackwell Publishers, 1993) 76. See also Thomas Ayck, Carl Zuckmayer in Selbstzeugnissen und Bilddokumenten (Reinbeck bei Hamburg: Rowolt Taschenbuch Verlag, 1977) 89.

${ }^{19}$ Vossische Zeitung, 26. 9. 30, in Gerhard F. Kramer, "The Influence of National-Socialism on the Courts of Justice and the Police," The Third Reich, ed. the International Council for Philosophy and Humanistic Studies (New York: Howard Fertig, 1975) 614. Cf. n. 4.

20 Kramer, 617.

${ }^{21}$ Kramer, 601.

${ }^{22}$ Carl Zuckmayer, Als wär's ein Stück von mir: Horen der Freundschaft (Wien: S. Fischer Verlag, 1967) 452. 


\section{ZEITSTÜCK IM MÄRCHEN}

Zuckmayer's Zeitstück, Der Hauptmann von Köpenick, was a biting satire of the lasting tradition of Prussian militarism under revival by a body of military parvenues with only limited claim to authentic political authority. Zuckmayer composed the Hauptmann von Köpenick as an "Eulenspiegelbild" of the German political environment of late $1930 .^{1}$ He clearly intended it as a portrayal of contemporary issues of highest relevance to his public at the time of his drama's premiere. Zuckmayer's drama was a social metaphor in which the public body could recognize itself for what it really was: a helplessly infantile outcast condemned to committing the same repeated mistake of self-deception. By 1931, the depression had economically disenfranchised the electorate from the lower middle class on down. A new class of military parvenues was attempting at that time to rise in the social ranks posing in borrowed, disgraced and previously discarded old military regalia to which it had no rightful claim but in fable. Zuckmayer formulated the literary assault of the Hauptmann von Köpenick against the rising power of the NSDAP into an attack on combined fronts. He brought the Volksstück elements present in his earlier works into direct confrontation with the Nazi myth of Deutschtum. ${ }^{2}$ He included a contemporarily critical attack of the NSDAP's ideological unification of the causes of the people and military. The Hauptmann von Köpenick assaults Prussian militarism at the root by reducing its symbols of authority to a discarded old uniform and the repetition of a childish interrogative. "Haben Sie gedient?" thus becomes the exclusive formula with which the military confines societal legitimacy to the members of its own caste. At this point in his literary career, the events of the time force Zuckmayer into an open reconfirmation of his earlier anti-war stance. ${ }^{3}$ The societally 
critical function of the Volksstück gains new emphasis as Zuckmayer shifts his attention to themes of contemporary urgency:

Mit dem Hauptmann von Köpenick stehen wir an einem

Höhephunkt in Zuckmayers Entwicklung. Das Schwergewicht seines Schaffens verlagert sich von nun an vom Volksstück auf das aktuelle Zeitstiick. Zweifellos haben die Zeitverhältnisse und die äußeren Lebensümstände zu dieser Entwicklung entscheidend beigetragen. ${ }^{4}$

Zuckmayer composed the dystopian fable of the Hauptmann von Köpenick as a biting satire on the politically ideological fable of the German race and the political danger its adoption represented to the German people. In true Volksstück fashion, he unmasked the essentially unchanged German political system and its inveterate court of monarchical legal representatives. With the Hauptmann von Köpenick, Zuckmayer composed a Zeitstück accurately portraying the mistakes of Germany's past and present that received a scathing review in Goebbels' reactionary Angriff. His drama served as a reminder that between 1906 and 1931 the institutions were essentially the same, but the people behind them were considerably different.

The element of fable with which Zuckmayer removed his satire of Prussian militarism from its chronologically specific setting leaves it in all ways open to interpretation in terms of contemporary events:

Wir wollen nicht bestreiten, daß der Dichter hier eine dramatische Fabel geschaffen hat, die nicht nur aus dem Leben geschöpft ist, sondern uber den kritisch ins Auge gefaßten historischen Vorfall hinaus auf ähnliche "Zustände" anwendbar bleibt. Trotzdem gelingt es nicht, dieses Stiick einfach als Zeitsatire zu verstehen, zumal es ja gar nicht einmal so sicher ist, daß diese "Zustände" so unbedingt als ausschließlich deutsche zu gelten haben. ${ }^{5}$

While acknowledging the critical relation of the Hauptmann von Köpenick to contemporary late Weimar political events, Paulsen recognizes the terms of universal applicability present in Zuckmayer's drama. Zuckmayer's comedy can thus be 
understood as a satire of the early twentieth-century trend toward military government and rearmament the world over.

Zuckmayer's Hauptmann von Köpenick hoped to awaken his public to the reality that although the government of Weimar was nominally republican, its controlling institutions preserved the lasting control of military-absolutist powers from the days before the outbreak of World War I.

At the time of its premiere in 1931, Zuckmayer maintained an incredibly tongue-in-cheek attitude toward the criticism of contemporary events concealed behind the Märchen epithet of his drama. Zuckmayer's synoptic overview of Der Hauptmann von Köpenick thus closed with the following claim:

Es will auch nicht mit den Leuten rechten, die die Verhältnisse gemacht haben, noch mit den Verhältnissen, aus denen die Leute wurden. Denn es ist ja nichts Neues, was es erzählt, sondern es ist ein deutsches Märchen und, wie alle Märchen längst vorbei, vielleicht uiberhaupt nicht wahr? - und nur ein Gleichnis für das, was nicht vorbei ist! 6

Behind the author's overt claim to purely fictional intentions lies an inherent truth with respect to chronological events. Despite the apparent transition to a more democratic form of government signalled by the proclamation of the Weimar Republic in 1918, the leading Verhältnisse had little changed since 1906 (or 1910, to which year Zuckmayer relocates the closing act of his play). Political events were in fact returning circumstances to an assertion of the stark authoritarian attitude of the prewar period. Zuckmayer's above claim that his drama does not desire to "dispute with those who have created the conditions" carries legal connotations. It is a satiric jibe at a justice system that blatantly supported reactionary political elements against the republican form of government of the Weimar Constitution. Zuckmayer had participated in a declaration in protest of Johannes R. Becher's prosecution for treason 
in 1928 and spoke in December 1930 at a gathering of the "Kampfausschusses gegen Zensur" in protest of the ban on the filming of Remarque's Im Westen nichts Neues. ${ }^{7}$ Zuckmayer's drama hoped to alert the German public to the fact that while their system was formally democratic, its controlling institutions were predominantly unaltered conservative-aristocratic survivals from the Wilhelmine era. ${ }^{8}$

Through his efforts at obtaining a rudimentary position of personal dignity within society, Voigt represents the spirit of human rights as opposed to institutional justice. ${ }^{9}$ Voigt incorporates the people's will to self-determination reflected in the Weimar constitution: "The German People, united in all their branches and inspired by the determination to renew and strengthen their commonwealth in liberty and justice, to preserve peace both at home and abroad, and to foster social progress, have adopted the following Constitution." 10 The Weimar constitution recognizes the people as the source of authority for Parliament. The judicial body adopted wholescale into the Weimar system of justice never had much intention of upholding the principle of the people's sovereignty or the conception of "liberty and justice" intended by the Constitution. ${ }^{11}$ Voigt's attempt at erasing apparent guilt by disguising himself in the costume of authority casts doubt upon the image of authority itself:

Je mehr Zuckmayer Voigt aufwertet, um so mehr wertet er die Huiter des Rechts ab. Diese umgekehrte Proportionalität wird begründet in der Unterscheidung von Legalität, staatlich sanktioniertem Gesetz, und Legitimität, natürlichem Recht. Weil Gesetz und Menschenrecht inkongruent sind, verstoßen die Vertreter des Rechts gegen das Recht, wenn sie den Buchstaben des Gesetzes exekutieren. Umgekehrt dient Voigt dem natürlichen Recht, wenn er durch seinen Streich das Gesetz des preußischen Staates verletzt. Aus dieser Paradoxie bezieht das Stuick seine Effekte, die dadurch noch gesteigert ist, daß er gegen das Gesetz mit dem Mittel des Scheins ficht, das diese Gesellschaft selbst legalisiert hat. ${ }^{12}$

By demonstrating Weimar's overobedience to symbols of authority and legitimacy, Zuckmayer launches his satire against one of the prime weaknesses in the system: its 
adherence to legal formalism to the ignorance of the justice it was meant to represent. Zuckmayer's description of the " 'Machtergreifung' in Deutschland, die nach außen hin scheinbar legal vor sich ging und von einem Teil der Bevölkerung mit Befremden, mit Skepsis oder mit einem ahnungslosen, nationalen Idealismus aufgenommen wurde," calls attention to the similarity between Voigt's action and that of his NSDAP counterpart. ${ }^{13}$ The difference is one of character and degree. Voigt strives to obtain a legitimate place among the Volk against the impediment of a legal technicality. Despite his repeated acts of treason, Hitler rose above the Volk behind a façade of legality. Zuckmayer's Voigt shows what can and did happen to a system of justice that loses track of what it stands for by concentrating its attention solely on a set of legal formulæ while ignoring the people and principles they represent.

Zuckmayer not only attacked the National Socialists through reference to current German political developments. He chose those elements in the Prussian military and ruling tradition under revival by the NSDAP as targets for satire. Voigt's slight criminal record condemns him to continual failure in finding work or obtaining a residence permit, both of which are contingent on eachother. He finally decides to purchase a twice-discarded, champagne-stained old captain's uniform (fifteenth scene). The uniform in general is a symbol of the age-old military tradition that had been recently disgraced in war and in repeatedly failed putsch attempts. ${ }^{14}$ Zuckmayer reduces the uniform to the level of the purely sachlich before mocking its lasting ability to command blind obedience from the members of the military. In the slapstick comedy of its third act, the Hauptmann von Köpenick openly mocks German society's enduring obedience to the institution of Prussian militarism. It scoffs at the readoption of military traditions by a class to which military authority had never traditionally belonged. In the fifteenth scene, Voigt snidely remarks on the price of the uniform he 
has just purchased. The second-hand dealer, Krakauer, responds: "Ich sag Ihnen: Se haben nich gekauft, se haben geerbt."(95). Krakauer makes verbal mockery of the uniform's power to command blind obedience: "Ihnen gesagt: es isse Wunder. Wenn die Uniform kennt allein spazierngehn, ohne daß einer drinsteckt - ich sag Ihnen, jeder Soldat wirdse grießen, echt isse!" (93). The National Socialists made full use of the uniform in attempting to provide themselves with the appearance of authority. Zuckmayer strips them of their apparent authority by placing the uniform in its historical context of disgrace and diminishing it to a second-hand article of reduced value. The crowning touch to Zuckmayer's satire of militarism comes, of course, in an unemployed cobbler's successful ability to retrieve the unwanted article and effectively use it in self-elevation to the status of commander.

Voigt's metamorphosis would be incomplete without a mastery of Beamtensprache down to the appropriate Redeformel to suit the situation. At the sign of the slightest resistance, Voigt, in his new role as captain, continually gains complete submission to his authority by repeating the same bark hurled his way for years. $\mathrm{He}$ emerges in full regalia from the restroom of the Schlesischer Bahnhof in the seventeenth scene. With the words, "Haben Sie gedient?," he commands the attention and obedience of the railway officials. When Obermuiller objects to Voigt's marching into his official chamber, Voigt stifles him by snapping out with the same question (107). As Rosenkrantz, the city treasurer, reports to Voigt, Voigt barks out a quick “Haben Sie gedient?" (108). Rosenkrantz unquestioningly responds to Voigt's command to close out the till. The military interrogative mirrors the claim to state authority with which the military had always asserted its position within society.

The Herrschaft of the Prussian state in Germany had long been founded upon a system of symbols designed to separate it from the common people. It was a heritage 
it adopted from the days of absolute aristocratic rule - from the days, when "Insignias, coats-of-arms, dress, hair styles, gesture, forms of address, dialects, all of these were used as status symbols, giving the public person an 'aura' of authority." 15 Immediately following their stunning victory at the polls on September 14, 1930, the National Socialists revived Prussian heritage in new form by dressing all of its 107 representatives in the uniforms of its party. ${ }^{16}$ Their attempt to gain control of the ministries of the interior and army through propagandistic intimidation failed:

Aber der Anspruch auf Besetzung des Innen- und des Reichswehrministeriums, mit dem sich die NSDAP vor ihrem Wahlsieg noch eine Machtbasis für die weitere Eroberung des Staates sichern zu können glaubte - denn er schloß die Verfügung über Polizei und Reichswehr, die unmittelbaren Machtinstrumente der Exekutive, in sich - , wurde sogleich durch weitergehende Forderungen überholt. ${ }^{17}$

Voigt makes a similar claim to military authority based completely on appearance. Zuckmayer's Voigt makes a mockery of the National Socialist revival of the aura of authoritarianism through his use of a uniform, official dialect and an implied claim to military service - none of which legitimately belong to him.

The stir created by the Hauptmann von Köpenick in the politically reactionary journal, Der Angriff, testifies to the effectiveness of its criticicism of current developments. Its satire of Prussian militarism cannot be denied even by Goebbels. Hitler's future Minister of Propaganda attempts to reappropriate his position as voice of the people by openly defending the primary objects Zuckmayer's dramatic satire ridicules:

... wohl nicht zu betonen, daß besagter Herr Zuckmayer sich die Gelegenheit nicht entgehen läßt, das alte preußische Regime, den verruchten Absolutismus, den Kadavergehorsam des ostelbischen Staates und den Blutbefleckten Militarismus mit Kuibeln von Spott und Hohn zu übergießen. ${ }^{18}$ 
Goebbels' reception of Zuckmayer's drama recognizes with intense accuracy its criticism not only of Prussian absolutism, but of the aggressive instincts relied upon by radical supporters of militarism as well. "Kadavergehorsam" describes the logical result of the sort of blind obedience to authority portrayed in the Hauptmann von Köpenick when transported to the battlefield. In the thirteenth scene, Augusta Wormser wears the uniform to a party. It gets spattered with champagne and compote (84). Goebbels sees Zuckmayer's symbolic degradation of the uniform as a reference to the blood with which it has been spattered in war. For this too, Goebbels praises the uniform. Goebbels' reception of the Hauptmann von Köpenick in the Angriff attempts to expropriate the dramatic appeal of the drama's military criticism by openly affirming the very elements of its condemnation. Goebbels not only defends the spirit of Prussian absolutism and the outward expression of its authority from Zuckmayer's satire. He uses the theatrical spattering of the uniform at a party as an occasion to glorify the reputation of death to which German militarism has become inextricably attached through the events of the First World War.

Contrary to Goebbels' ascertainment of blatant military criticism in the Hauptmann von Köpenick, in Zuckmayer's drama, obedience to authority never results in direct physical injury to anyone. The only parallels to Ernst Toller's notorious $1932 \mathrm{jag}$, "Soldaten sind Mörder," are indirect. Voigt states to Hoprecht in the fourteenth scene: "Aber se sollen mir drin leben lassen in de Heimat. Denn könnt ick auch sterben für, wenn's sein muß" (90). Voigt's complaint is a poke at the ludicrous expectation of "Kadavergehorsam" to military authority applied domestically. Subjects treated inhospitably at home by militaristic officials could hardly be expected to selflessly devote their lives to the system. Voigt's reading of the passage from the Bremer Stadtmusikanten: "Komm mit, - sagte der Hahn, etwas 
Besseres als den Tod werden wir überall finden" (78), echoes the same sentiment. The implicit message of peace is, however, anything but completely obvious. The ambivalence of comic irony certainly makes it possible to interpret Voigt's coup as a justification for the exercise of military might, although Zuckmayer clearly strove for an opposite effect. ${ }^{19}$

Zuckmayer's comedy is by no means an open avowal of the glory of Prussian militarism. Yet even if it had been, its military theme would have made it a likely target for attack from the Nazi press anyway. ${ }^{20}$ The success of comedy depends largely upon its ability to transform even life-threatening themes into harmless objects of public amusement, "for laughter has no greater foe than emotion."21 Zuckmayer's Hauptmann von Köpenick attacks the inevitably destructive results of the cult of militarism in only the subtlest of ways.

Zuckmayer's satirical attack of the lack of true authority of resurgent military groups puts Goebbels on the defensive. Goebbels recognizes Zuckmayer's criticism of the lasting power of militarism. He attempts to snuff out the meaning of its reference to misappropriation by a class lacking traditional authority:

Wir sind nicht gegen die Tendenz auf der Bühne; aber die Tendenz muß dann auch im Dienst des Besseren stehen und darf sich nicht damit begnügen, aus der Tatsache, daß die Personen gewechselt haben, auch die vermeintliche Tatsache zu schöpfen, daß das System anders geworden sei. 22

Here Goebbels fully misses his mark (the same observation he claims to make about Zuckmayer). ${ }^{23}$ The heart of Zuckmayer's critique of militarism rests on the fact that the system is indeed the same. ${ }^{24}$ Zuckmayer lampoons a system under which nobody wins. He mocks a system that holds the dispossessed at bay, until the dispossessed take revenge upon society by turning the system's tools against it. Goebbels' guileridden attempt to usurp this aspect of Zuckmayer's appeal to the German people's 
sense of wakefulness to awaiting danger is typical. Goebbels attempts to expropriate Zuckmayer's exposure of politically current trends through blatant affirmation of their veracity. The reaction of the editor of the Angriff shows the effectiveness of Zuckmayer's Zeitstück at revealing the societally dangerous elements in the program of the rapidly swelling Nazi party. The fact that Goebbels proudly and openly acknowledges those elements indicates that despite his call to action, Zuckmayer appeals too much to human reason and not enough to feelings of indignation.

The Hauptmann von Köpenick directs its attention to life-like depiction at the lasting historical trends affecting the Weimar Republic and the lack of traditional authenticity in resurgent militarism of the NSDAP. The anti-militarism of the Hauptmann von Köpenick was generally applicable to military developments everywhere. Elevated from the immedediate context of the original Rathaus Überfall, the Köpenickiade was now in a position to directly address the political developments of 1931. The Köpenickiade as fable was a symbolic demonstration of the fact that despite the Kaiser's abdication and the declaration of a democratic republic "auf deutschem Boden," the institutions of monarchy continued to hold their grasp upon society. Nothing had changed. A conservatively aristocratic judiciary assured the negation of the rights of the person supposedly represented by the system as it protected the interests of the resurgence of the lasting institution of Prussian despotism. Voigt's symbolic struggle against the mastery of the bureaucracy is thus a true-to-life depiction of the Weimar Republic's inability to free itself from the increasingly heavy yoke of Prussian tyranny. Goebbels' hefty reaction to Zuckmayer's drama shows the latter's effectiveness at getting to the root of the contemporary danger of European fascism. It also indirectly indicates that mere awareness of the problem was no longer an effective deterrent. The accurate 
correspondence between the Hauptmann von Köpenick's fabulous elements and the political environment at the time of its premiere truly make it "mehr Zeitstuick als die Zeitstiucke," as Alfred Kerr so acutely observes. It is precisely this aspect that makes Zuckmayer's drama an interesting contribution to the field of social history. 


\section{ENDNOTES}

${ }^{1}$ See Zuckmayer's statement in note 38 on page 74 .

2 See pages $66-67$, notes 40 and 41.

${ }^{3}$ The young Carl Zuckmayer had been vacationing with his parents in Holland after the heir to the throne of Austria was assassinated in Sarajevo on June 28, 1914. As the communications passed between Austria, Serbia, Russia, France and Germany, Zuckmayer and his family awaited the inevitable: " 'A war in our times is madness, atavism,' my father said. 'It would plunge the whole world into ruin. No one will go so far." "The night after his father spoke those lines, Zuckmayer composed two poems of pacifism that he dispatched to the editor of the Frankfurter Zeitung. Once back in Germany, he received notice that his poems had been accepted for publication: "The letter informed me of the acceptance of my 'highly gifted poems' whose spirit 'accorded fully' with the views of the editors." Two days later he received a second letter stating that the editor's previous views had become obsolete, and that it was now "clearly essential to defend the ideal of a peaceful world with sword in hand, ... words which struck me as utterly persuasive." On August 1, 1914, when the German Emperor announced the mobilization for war to proceed on the following day, Zuckmayer immediately ran to Schillerplatz in Mainz in order to enlist in the German regiments: "Only two nights earlier I had said to a Dutchwoman that I would never take part in war. Now there was no longer the slightest residue of any such feeling." Carl Zuckmayer, A Part of Myself, trans. Richard and Clara Winston (New York: Harcourt Brace Jovanovich, 1970) 137-45.

4Martin Greiner, "Carl Zuckmayer als Volksdichter," Theater und Gesellschaft : Das Volksstück im 19. und 20. Jahrhundert, ed. Jürgen Hein (Duisseldorf: Bertelsmann Universitätsverlag, 1973) 169.

5Wolfgang Paulsen, "Carl Zuckmayer," Deutsche Literatur im 20. Jahrhundert: Strukturen und Gestalten, vol. 1, Strukturen (Bern und München: Francke Verlag, 1954) 312.

$6^{6}$ Carl Zuckmayer, in Werner Frizen, Der Hauptmann von Köpenick (München: Oldenbourg, 1988) 95.

7Jochen Becker, Exil und Rückkehr: Emigration und Heimkehr: Ludwig Berger, Rudolf Frank, Anna Seghers und Carl Zuckmayer, ed. Anton Maria Keim (Mainz: Verlag H. Schmidt, 1986) 138.

8In connection with Zuckmayer's above claim that his Märchen explained nothing new, Obermüller's statement becomes a biting satire on the Weimar Republic if one reapplies its elements to fit the period. "Das System ist monarchisch, aber wir leben angewandte Demokratie" is an obvious nonsequitur. But if one translated the formula to fit the Weimar period, a spectator might have come up with "das System ist 
demokratisch, aber wir leben angewandte Monarchie," which would have been nearly true of Weimar ruled under Article 48 of its constitution.

${ }^{9}$ Voigt is more than just another Götz von Berlichingen taking justice into his own hands. In comparison with earlier criminal figures in German drama: "While in Der Biberpelz the public authority dispenses no justice, in Zuckmayer's drama the state officials dispense injustice, "n sauberes glattes Unrecht'." Rudolf Koester, "The Ascent of the Criminal in German Comedy," German Quarterly 43 (1970): 376-93.

10Hugh Quigley and R.T. Clark, Republican Germany: A Political and Economic Study (New York: Howard Fertig, 1968) 49.

11"Mit dem Untergang des Kaiserreichs und der Ausrufung der Republik ausgerechtnet auch noch durch einen Sozialdemokraten - brach für die monarchistisch eingestellte Richterschaft eine Welt zusammen. 'Jede Majestät ist gefallen', klagte der Vorsitzende des Richterbundes, Johannes Leeb, 'auch die Mäjestät des Gesetzes.' In den Gesetzen der Republik sah er 'Luigengeist', 'Partei-, Klassen-, Bastardrecht'. Der Richterschaft wurde jedoch ihre Unabhängigkeit und Unabsetzbarkeit garantiert, und Richtern, die es nicht mit ihrem Gewissen vereinbaren konnten, der Republik statt dem Kaiser zu dienen, bot die Regierung an, sich bei Wahrung aller materiellen Anspruiche in den Ruhestand versetzen zu lassen. Von diesem Angebot machten jedoch weniger als 0,15 Prozent der Richter Gebrauch." Ingo Müller, Furchtbare Juristen: Die unbewältigte Vergangenheit unserer Justiz (München: Droemersche Verlagsanstalt Th. Knaur Nachf., 1989) 20-21.

\section{Frizen, 43.}

\section{${ }^{13}$ Carl Zuckmayer, Als wär's ein Stück von mir: Horen der Freundschaft} (Wien: S. Fischer Verlag, 1967) 71.

${ }^{14}$ The members of the Kapp putsch of March 1920 even wore swastikas on their helmets to show their support, and the supporters of Hitler's putsch attempt of November 9, 1923 carried swastika flags. John H.E. Fried, "Fascist Militarism and Education for War," The Third Reich, ed. the International Council for Philosophy and Humanistic Studies (New York: Howard Fertig, 1975) 748-52.

15Robert M. Berdahl, The Politics of the Prussian Nobility:The Development of a Conservative Ideology: 1770-1848 (Princeton: Princeton University Press, 1988) 66-67.

16Helmut Heiber, The Weimar Republic, trans. W.E. Yuill (Oxford, U.K. and Cambridge, U.S.A.: Blackwell Publishers, 1993) 177. See above, page 1, note 5.

17Karl Dietrich Bracher, Die Auflösung der Weimarer Republik: Eine Studie zum Problem des Machtverfalls in der Demokratie (Villingen/ Schwarzwald: RingVerlag, 1964) 360. 
18Joseph Goebbels, Der Angriff: Das deutsche Abendblatt in Berlin 12. März 1931: 1 .

19Berman sees Helmut von Käutner's 1956 production of the Hauptmann von Köpenick as an ideological piece of propaganda that "argues for the Bundeswehr by presenting the values of a sentimental nationalism." Russel A. Berman, "A Return to Arms: Käutner's the Captain of Köpenick (1956)," German Film and Literature: Adaptations and Transformations (New York: Methuen, 1986) 172.

20 Even had Zuckmayer's Hauptmann von Köpenick been fanatically militaristic, the National Socialists would probably have received it as not fanatical enough. Fanatical attack was the method they used to subsume their rivals within the movement: "First of all, the [rival organizations] did not push resolutely enough the interests of the military forces. Here the National-Socialist equation of patriotism paid the best dividends. Armaments, a bigger military establishment, more military prowess in every respect - only he who worked ceaselessly for these aims, with complete disregard of considerations and consequences, was a patriot. No other party clamoured for these things as they did: they were the true patriots. Their young 'activists' did not hesitate to beat up old women who had lost their sons in the war, and who now had the insolence to demonstrate for disarmament. They set themselves up as arbiters and jealous guardians of the national good, and by putting the target always a few degrees beyond the attainable, were always able to show that their rivals fell short of the goal." John H.E. Fried, "Fascist Militarism and Education for War," The Third Reich, ed. the International Council for Philosophy and Humanistic Studies (New York: Howard Fertig, 1975) 752.

21 Henri Bergson, Laughter: An Essay on the Meaning of the Comic, trans. Cloudesley Brereton (New York: The Macmillan Company: 1917) 4.

22 Goebbels, 1 .

${ }^{23}$ Goebbels' paragraph opens thus: “Aber schaut hin und seid mit uns der Meinung: es ist ein Schuß ins Leere, den Herr Zuckmayer abgibt. Selbst in der Karikatur wirkt das Preußentum noch so überzeugend, daß es auch der heroisierten Gegenwart gegenüber den Vorrang beanspruchen kann." Goebbels, 1.

${ }^{24}$ The uniform passed down from the aristocratic Schlettow to the bourgeois Obermuiller and the craftsman, Voigt, is the same old uniform symbolic of the same old system. 


\section{CONCLUSION}

Carl Zuckmayer's Hauptmann von Köpenick draws on the full range of literary techniques to create a satire of the human will at odds with a system of bureaucratic order grown inhuman. The principal conflict returns drama to its ancient roots. Voigt's conflict with the forces of bureaucracy repeats the opposition of the power of chaos to the societally ordering function of cosmos in the ancient Greek theater. But Zuckmayer makes the theme highly modern at the same time. He combines the most recently popular movements of Expressionism and the Neue Sachlichkeit into the formulation of the subjective-objective antithesis that forms the modern thematic underpinning to Voigt's conflict with the military bureaucracy. Zuckmayer converts history into myth in repetition of the age-old literary practice dating back to Homer. The National Socialists used and created their own myth in a failed attempt to subject history to a Romantic ideology. Zuckmayer consolidates his attack against the rising power of the NSDAP by usurping the chief elements of their appeal to the German people. He establishes the traditional Volksstück link with the people by returning the Volksstück address to the people's sense of social criticism to its former position of primacy. He reasserts the traditional German Humanistic ideal against reactionary parallels founded in the Prussian authoritarian tradition. The central dramatic conflict of the Hauptmann von Köpenick symbolizes the enduring struggle of the German people for hegemony against its traditional military-authoritarian rival. Zuckmayer alters the excerpted line from the Bremer Stadtmusikanten while remaining true to its spirit, thus drawing attention to the curious relationship between sachlich appearance and meaningful content. His retelling of the sensational Rathaus seizure of 1906 appears harmless enough on the surface. But underneath lies the assertion that, upon the drama's premiere in 1931, Germany was back in the same old position of 
domination by the cult of the uniform that it had been under the Kaiser. It is the absurdity of the dilemma of the German people's return to the yoke of military absolutism that the German playwright, Carl Zuckmayer, captures in his Hauptmann von Köpenick: ein deutsches Märchen in drei Akten.

By cleansing Voigt of personal responsibility for his placement at the fringe of society, Zuckmayer conjures up the traditional dramatic conflict between chaos and cosmos and revives the ancient thematic ingredient of superhuman fate. Zuckmayer returns drama to its natural roots in antiquity through close adherence to traditional structural and thematic elements. In terms of form, Zuckmayer's drama conforms to the theatrical tradition passed down from the late antique period:

Mit dem Dreischritt der dramatischen Entwicklung: Exposition (Protasis), Epitasis, Katastrophe (Lysis) uibernimmt Zuckmayer eine 'klassische' Form, die schon in der Spätanticke entworfen, vor allem im romanischen Sprachbereich praktiziert und in der Komödie vor allem von Cervantes verwandt wurde. ${ }^{1}$

But in the dialectic of exclusion and inclusion represented by Voigt's struggle against the bureaucracy, Zuckmayer returns to the thematic duality between chaos and cosmos of Ancient Greek theater:

Noch aus der Zeit der Urhorde stammten die Vorstellungen von Kosmos und Chaos. Hier das Leben einer solchen kleinen Gruppe von Menschen: Sie lagert um das Feuer, das die wilden Tiere und die Kälte abhält. Was durch den Schein des Feuers abgegrenzt, gesichert ist, das ist der Raum des Menschen, ubersichtlich geordnet: der Kosmos. Alles, was außerhalb liegt, ist Naturgewalt: Urwald, feindliche Tiere, Hunger, Drohend-Unbekanntes. Das ist das Chaos - das Ungeordnete, Gefährliche und Gefährdende. Im Chaos herrschen die vom Menschen noch nicht bewältigten Kräfte der Natur. ${ }^{2}$

Zuckmayer revives the ancient chaotic element in Voigt, whom he places beyond the pale of the organizing cosmos of bureaucratic society. The Hauptkonflikt of the plot of the Hauptmann von Köpenick is that between Mensch and Ordnung. As an 
outsider, a Mensch excluded from the orderly societal realm, Voigt's Naturverbundenheit makes him a reincarnation of the natural forces of chaos within humanity. Voigt's coup against the bureaucratically exclusive Menschenordnung finds conceptual motivation in the animals' revolt of the Bremer Stadtmusikanten, the Grimms's tale he reads to Liesken at the twelfth scene's close. Through exclusion from the Kosmos of the bureaucratic system, Voigt becomes the incarnation of naturally animalistic drives (although Zuckmayer makes them appear harmless enough in preservation of their comic effect). Hoprecht's statement at the end of the fourteenth scene signals Voigt's entry into the realm of Chaos beyond the system's control: "Der Mensch — der Mensch ist ja gefährlich!!" (92). The Wilhelm Voigt who achieved celebrity through his seizure of the Köpenicker Rathaus in 1906 was criminally motivated. The Voigt of the drama is completely driven by circumstance. By purging the character Voigt of the aspect of guilt, Zuckmayer places him in the hands of fate:

Moira, das ist urspriunglich das Los bei der Verteilung der Beute, bei der Verteilung des Landes. Das Los entscheidet unparteiisch, unabhängig vom Willen und Hoffen der Menschen - es ist das Sinnbild einer Entscheidung, die vom Menschen unabhängig ist, aber sein weiteres Ergehen bestimmt. ${ }^{3}$

Zuckmayer revives the concept of Los in the form of a humanly created bureaucracy grown indifferent to humanity. Fate's overbearing power reveals itself as it exerts its hegemony even over its leading human representatives, incapacitating the willpower of Schlettow and Obermuiller, Hoprecht and Voigt alike through its rigid enforcement of authoritarian principles. The twist Zuckmayer throws into the ancient scheme emerges at the point where Voigt asserts his will against a fate that has excluded him, enjoying a short-lived Pyrrhic victory in demonstration of the glaring weakness of the bureaucratic apparatus. ${ }^{4}$ The Neue Sachlichkeit's goal of achieving realistically 
impartial representation renders it the perfect form for the incorporation of the ancient element of fate. Zuckmayer's talent lies in rejuvenating theater not by revolutionary means, but by returning it in large measure to its original form. He founds his critique of modern society upon a return to the ancient formulæ of drama in the early stages.

By equating historical event with fairy tale, Zuckmayer parodies the ideological practice of presenting preconceived myth as historical fact. He thus titles his drama, Der Hauptmann von Köpenick: ein deutsches Märchen in drei Akten:

Die Bezeichnung Märchen ist zum Teil ironisch zu verstehen, sie bezeichnet das Geschichtsverständnis des unpolitischen Deutschen und seine Wirklichkeit. In einem weiteren Sinne ist aber das Märchenschema, wie bereits ausgeführt, ein Grundmoment der Zuckmayerschen Volksstiicke. ${ }^{5}$

Yet the transformation of historical into fabulous event is the work of the dramatist. Zuckmayer's use of the phrase, "ein deutsches Märchen in drei Akten," to complete the title gives subtle indication of dramaturgical propriety with respect to historical fact. Zuckmayer's title is identical in form to ideological equations of history and myth. Its formal identity to ideological statements draws attention to the underlying difference contained within it. The transformation of historical events into mythical form is wholly in keeping with western tradition. The reality reflected in dramatic fiction may serve to increase humanity's understanding of human relations. The attempt to impose mythological conceptions upon the public realm is the work of the demagogue, and to the mind of a thinker like Zuckmayer, a perversion of justice in its purest form.

Zuckmayer's theatrical reflection of contemporary reality contrasts markedly with the mythological elements the National Socialists imposed upon political and social reality under the Third Reich. Zuckmayer incorporates the Romantic element of the fabulous third prince into his leading character in order to truthfully portray the 
reality of situations in Germany in 1931. Hitler used the Romantic elements of nationalism and fable with which to create the myth of the Third Reich. Zuckmayer employs the symbol of the rooster as wakener to rouse the German people to awareness of the lurking danger represented by the human masters of the Bremer Stadtmusikanten. Hitler's Nazis used the slogan "Deutschland Erwache" and the fiction of the German Master Race with which to enslave an entire nation like animals and elevate their leader to the status of prince, of Dark Prince, of the "Teufel auf Erden" of Zuckmayer's Teufels General. ${ }^{6}$ Zuckmayer's use of the techniques of Neue Sachlichkeit and Expressionism in the Hauptmann von Köpenick illustrate, through example, the attitude of detachment and hopelessness of which Hitler took advantage as he duped an entire nation into allowing itself to be subjected to his Führerprinzip. Its founders made every attempt to provide the Third Reich with mythical historical foundations:

Ein solch altes Wort ist das Dritte Reich, klangvoll allein schon durch die Dreizahl ('wie im Märchen'), klangvoll als dritte Krönung Deutschlands (nach dem mittelalterlichen und dem Bismarckschen Reich). Damit aber der revolutionäre Schein nicht zu kurz komme, fügte Moeller van den Bruck, der eigentliche Erneuerer des Terminus, mystische Überlieferungen aus ganz anderen 'Reichen' hinzu. Denn im Original hatte das Dritte Reich den sozialrevolutionären Ideal-traum der christlichen Ketzerei bezeichnet: den Traum von einem Dritten Evangelium und der Welt, die ihm entspricht. ${ }^{7}$

Zuckmayer's conception of the world as a unified whole finds structural and thematic reflection within his drama. The National Socialists projected their narrower view of a world in conflict onto Germany, Europe and the World. By taking an historical event and transforming it into a dramatic fairy tale, Zuckmayer reinforces the age-old traditional division between theatrical and political events. In his autobiographical Pro Domo he writes: "Die Schaubühne ist eine metaphysicshe Anstalt, mehr noch als eine 
moralische, und um das zu sein und zu bleiben, muß sie bis in alle Fasern von vitaler Wirklichkeit, vom leibhaftigen Eros, von allen Essenzen des Menschenlebens durchtränkt werden." 8 The stage incorporates the broadest scope of reality to create its own mythical world separate from the reality of social and political events. The Hauptmann von Köpenick mirrors the socio-political consequences lurking in a system of bureaucratic forces grown indifferent to the society it has been created to serve. Zuckmayer demonstrates the inherent absurdity in the active translation of mythical vision into political reality through his account of Voigt's divinely inspired Pyrrhic victory against the forces of bureaucracy. His deutsches Märchen in drei Akten correctly applies the relationship between history and myth to the fictional world of drama. He includes mythical elements in his drama to create a humanistic parallel counter to similar elements in National Socialist doctrine, thus bringing attention to the abuse of the historical-mythical relationship by the proponents of the latter. ${ }^{9}$

Zuckmayer's reliance upon tradition as well as his choice of dramatic genres and themes allow him, like Brecht, to consolidate his dramatic argument against National Socialism.

The Volksstück genre establishes the same immediate link to the German people that Hitler attempted to justify through his imposition of the Führerprinzip, or leadership principle. With remarkable constraint for a man whose partial Jewish parentage made him a target for Nazi slander and subsequent persecution, Zuckmayer confines racial references in the Hauptmann von Köpenick to the fringes in order to focus his attention on the inherent conflict between military and societal authority. The military bureaucracy in the Hauptmann von Köpenick undermines aristocratic principles, places the intelligentsia under military occupation and barricades the people from its rightful place in society. Von Schlettow retires from military service 
for attempting to maintain discipline out of uniform. An unemployed cobbler wrests governmental authority from Dr. Obermüller clad in the latter's discarded old uniform. The bureaucracy denies Voigt entry into society through its adherence to an objective set of rules that fail to account for the welfare of the people. Zuckmayer metaphorically reflects the lasting struggle of the German people for selfdetermination against the forces of military authoritarianism. His drama attacks the coming reimposition of the Führerprinzip, "which effectively deprived any member of the Volksgemeinschaft of any active and positive participation in the political and institutional decision-making process." 10 Before the Reichstag, Hitler placed the people above the system: "Party, state, army, the economic structure, the administration of justice are of secondary importance, they are but a means to the preservation of the Volk." 11 But in reality, the Rechtsstaat represented the interests of the Volk to the latter's exclusion from decision making. The Rechtsstaat was subordinate to the authority of the NSDAP and its openly military aims. ${ }^{12}$ Zuckmayer's Volksstück leaves the power of judgment to the people against militaryabsolutist claims to hold and exercise that power in the people's name. By demonstrating the societally deleterious effects of military authority from many angles, Zuckmayer's drama urges its audience to a reevaluation of its actual political circumstance within the hollow exterior of Menschenordnung upon which the military authorities found their claims.

The Volksstück genre enables Zuckmayer to synthesize modern and traditional theatrical elements into an attack of a combination of revolutionary and conservative trends that are on the brink of desroying the established order of the Weimar Republic. Elementary to Zuckmayer's keeping to the Volksstück genre in the Hauptmann von Köpenick is the possibility it allows for the combination of the styles of soziale and 
historische Dichtung, Expressionism, Neue Sachlichkeit, and Zeitsstück. He relies on a full range of genres in concentrating his critique upon the lasting militarybureaucratic trend so threatening to the new German political order. Yet by operating within the Volksstück genre, he is able to compete in closed combat against the conservative reversion to traditional conceptions characterized by other of the genre's adherents:

Unbekümmert um die Kritik, welche die große realistische Literatur an dergleichen Vorstellungen übte, gab die Gattung zu verstehen, kleinstädtisches, ländliches Leben, die Reste des vorindustriellen Zustands, taugten mehr als die Stadt; der Dialekt sei wärmer als die Hochsprache, die derben Fäuste die rechte Antwort auf urbane Zivilisation. Im Volksstiick tobte die Rancune derer sich aus, die, ausgeschlossen von der offiziellen Kultur oder nicht mitgekommen mit ihr, einen engen Sonderbereich sich reservierten, wo sie endlich Mensch sein, nämlich so unmenschlich sein durften, wie sie wollten. ${ }^{13}$

Adorno's analysis attacks the Volksstück genre at the point of its greatest proximity to the same tendency in fascist ideology. Zuckmayer's Volksstück attacks the same ideology by describing the struggle of the people against depersonalization and disinheritance by the military "state within a state" symbolic of the NSDAP. He thus attempts to wrest the Fascist appeal to the Volk by defining the Volksstück genre in his own terms. His definition of Volk refers to the German Humanistic tradition, and as concept, corresponds directly to that of humanity: "Erst der Mensch, Friedrich! Und dann de Menschenordnung!" (89). Like every so-called revolutionary movement, the National Socialists based their Weltanschauung upon a return to an idyllic state of affairs that they placed in the mythical past. In the fourteenth scene of the Hauptmann von Köpenick, Hoprecht attempts to convince Voigt to obey the order for his expulsion: "'n Mensch biste uiberhaupt nur, wenn du dich in ne menschliche Ordnung stellst! Leben tut auch 'ne Wanze!" (89). Voigt poses his own idea of the correct 
relationship between institutions and the people they represent: "Richtig! Die lebt, Friedrich! Und weißte, warum se lebt? Erst kommt die Wanze, und dann die Wanzenordnung! Erst der Mensch, Friedrich! Und dann die Menschenordnung!" (89). Zuckmayer returns to the traditional genre of Volksstück to demonstrate to his audience that in the politically militaristic ideology of the NSDAP, the so-called "Menschenordnung" comes before the "Mensch," and the "Wanzenordnung" before the "Wanze" it creates of the human spirit.

Zuckmayer uses the techniques of Expressionism and the Neue Sachlichkeit with which to accentuate the central dramatic conflict represented by an individual's attempt to maintain his human identity against a hollow barricade of bureaucracy. In a critique of Erich Kästner's use of the technique, Walter Benjamin describes the emptiness of feeling characteristic of the Neue Sachlichkeit:

Nach diesem Werbefeldzug schritt sodann die Neue Sachlichkeit, aus der die Kästnerschen Gedichte stammen, zur Inventur. Was findet "die geistige Elite", die an die Bestandsaufnahme ihrer Gefühle herantritt denn vor? Diese selbst etwa? Sie sind längst verramscht worden. Was blieb, sind die leeren Stellen, wo in verstaubten Sammetherzen die Gefühle - Natur und Liebe, Enthusiasmus und Menschlichkeit - einmal gelegen haben. Nun liebkost man geistesabwesend die Hohlform. ${ }^{14}$

Zuckmayer reduces the Neue Sachlichkeit, in part, to an internal stylistic component accentuating the central dramatic conflict of the Hauptmann von Köpenick. The neusachlich "Hohlform" of Zuckmayer's drama becomes the uniform: the symbol of bureaucratic authority made meaningless by an aging man's masquerade against the system. The Neue Sachlichkeit is the "Hohlform" of a set of institutions whose claims to political impartiality render them powerless against the National Socialist seizure of power by technically "legal," or perhaps more accurately, sachlich means. Zuckmayer reverts to Expressionist techniques in formulating the principal dramatic conflict of 
Der Hauptmann von Köpenick against the bureaucratic powers of Sachlichkeit. The reversion signals an attempt at reevaluating theater in terms of the dramatic movement in popularity at the time of the foundation of the Weimar Republic. Zuckmayer uses the techniques of Expressionism and Neue Sachlichkeit in symbolic reformulation of the disparity between the democratic will of the German people and the inveterate spirit of monarchy in its adopted institutions.

The principal conflict of the Hauptmann von Köpenick is not only the subjective struggle of the enduring power of chaos against the objective cosmos of the German military bureaucracy. On the socio-historical level, it is the battle of the German people for sovereignty against the controlling grip of military absolutism. The constitution of the Weimar Republic reflected the spirit of republicanism. But its institutions concealed the unseen will of the Kaiser. Symbolic of the hidden forces of monarchy still thriving under the Weimar Republic, the Kaiser's laughter of approbation for Voigt's excapade enters the dramatic action of Zuckmayer's drama from beyond the scenes (121):

Die Bedeutung und die Stellung der politischen Justiz in der Weimarer Republik ist nur zu verstehen vor dem politischen Hintergrund und aus den Voraussetzungen dieses Staatswesens, seiner gesellschaftlichen und seiner geistigen Umstände. Die Weimarer Republik war das erste Experiment eines demokratischen Gemeinwesens in der deutschen Geschichte. Nach dem Scheitern der Revolution von 1848 hatten sich Staatsbildung und Gesellschaftsentwicklung in den Formen einer nur äußerlich modernisierten, obrigkeitsstaatlich strukturierten Monarchie vollzogen. Ihre Elemente uiberdauerten auch den Sturz der Monarchie und die Erschütterung der Revolution von 1918. Die Demokratie war aus der Niederlage, aus dem Zusammenbruch geboren, sie wurde mit den Umständen und den Konsequenzen dieses Zusammenbruchs voll belastet, während wesentliche Elemente des alten Systems sich erhalten und neu stärken konnten. ${ }^{15}$

The judiciary, military and the police under Weimar were unwilling to protect the people's sovereignty against attacks from the reactionary right. The Brüning 
government excluded the cornerstone of democratic representation, the German Parliament, by invoking Article 48 of the constitution. Voigt's expulsion order is symbolic of the fact that, beginning in the 1930s, the German people had been excluded from a determing role in its affairs. The Ausschaltung had begun. The Gleichschaltung, the NSDAP imposition of a uniform structure on German society was well on its way before Hitler came to power on January 30, 1933. Voigt's struggle for identity is the struggle of the German people against total subjugation to the inhuman mastery of an undignified military-bureaucratic apparatus.

Zuckmayer's reformulation of the "Komm mit" invitation of the twelfth scene into the "Kommt mit" general convocation is typically sachlich in the subtlety with which Zuckmayer carries it out. Neither line fits the tale as told in the Brothers Grimm. But each fits the spirit of the tale directly to its circumstance. For the second variation appended to the conclusion of his drama, Zuckmayer includes a parenthetical citation of the authors and the tale from which he excerpted it. The underlying message behind Zuckmayer's subtle alteration is that Sachlichkeit, like a uniform, is merely a façade. To actually get to the truth, one has to pay objective attention to detail as well as relying upon instinct to get to the spirit behind surface appearances. Otherwise one runs the risk of unjustly condemning an innocent man to societal expulsion, or of obeying the commands of what appears to be an army captain in a spattered old uniform.

The link Zuckmayer creates between contemporary reality and the timeless element of fable provides for the Hauptmann von Köpenick's portrayal of the sociopolitical events of Weimar in terms of their relationship to enduring historical trends. Zuckmayer's synthetic approach forces neighboring syntheses in broad terms. Historical events soon prove the predominant threat to the Weimar Republic to consist 
in a reversion to lasting political, against cultural trends. The renouned twenties critic, Alfred Kerr, fully recognizes the elevated relevance to contemporary developments of Zuckmayer's play, which he considers "Mehr Zeitstiick als die Zeitstuicke." He sees in the uniform the lasting symbol of monarchic authority devouring the soul of the Weimar Republic from within. He concludes his Rezension with a plea to action echoing the same dramatic theme in Zuckmayer. It could easily serve as an epitaph to the Weimar Republic:

Aber wer schreibt mir ein Stück der deutschen Geschichte; der übel erprobten tausendjährigen Vergangenheit ..., das vielleicht ihr abzuhelfen vermag? Heute das Schauspiel einer Republik ..., die mit sehenden Augen alles zuläßt, was auf ihren Sturz gerichtet ist?

Und die nicht eingreift.

Wer schreibt es, ... wenn auch zu spät??? ${ }^{16}$

The historical parallels between the events of the third act of Zuckmayer's Der Hauptmann von Köpenick and the emergence of the Third Reich form a direct link between the irony of Zuckmayer's Märchen in drei Akten and the reality of its historical context. Similar to the majority of later literary critiques of the drama, Ludwig Marcuse's article of March 7, 1931 ignores the criticism of contemporary events contained in Zuckmayer's depiction of what Marcuse calls, the "Despotismus der Uniform":

Er zeichnet nur nach - und nimmt beim Nachzeichnen sein Objeckt nicht sehr ernst. Er demonstriert eine Kuriosität im Raritätenladen Weltgeschichte. Er schreibt ein historisches Stück, das er nicht auf die Kämpfe unserer Zeit bezieht, sondern unter den Blickpunkt des zeitlosen Humors stellt. Keine Silbe davon, daß wir acht Jahre nach dem 'Hauptmann von Köpenick' den Weltkrieg hatten. ${ }^{17}$

Marcuse's response is typical. It demonstrates that in the politically heated environment of the early thirties, Zuckmayer's humor was either a little too subtle or too effective on the surface level for its public to grasp the connection between its underlying themes and immediate political reality. The supreme irony of Marcuse's 
statement is that eight years after Zuckmayer's version of the events surrounding the "Hauptmann von Köpenick" premiered on stage, Germany was engaging in a second "World War." Zuckmayer's Zeitstück so closely mirrors the actual history of its period, that it would be hard to imagine an historical drama that could better capture the spirit of events surrounding the period of its premiere on March 5, 1931.

Zuckmayer's synthesis of the Neue Sachlichkeit with Expressionistic and fairy tale stylistic elements forms the bond between reality and fiction that makes the Hauptmann von Köpenick "mehr Zeitstiick als die Zeitstiicke." Zuckmayer's use of fable to establish the mimetic link between fact and fiction is fully traditional. ${ }^{18}$ Zuckmayer repeatedly combines his concept of Märchen as "Gleichnis" with the interrelationship between historical past and present. He relies strongly on traditional dramatic ingredients with which to form a connection with currents of modern literature as well, so that the closing chant of the "Chorus Mysticus" in Goethe's Faust could easily have been written as a description of Zuckmayer's dramatic technique with respect to Zeitstück:
Alles Vergängliche
Ist nur ein Gleichnis;
Das Unzulängliche, hier wird's Ereignis;
Das Unbeschreibliche, hier ist's getan;
Das Ewig-Weibliche zieht uns hinan. ${ }^{19}$

History, "das Vergängliche," forms the basis for Zuckmayer's fabulous "Gleichnis." The "Ereignis" of the Köpenickiade results from the "Unzulänglichkeit" of the Prussian military bureaucracy at reaching a humanly adequate solution for the civically well-intentioned Voigt. Or as the Berliner Morgenpost stated in 1906: "Die Traurigkeit, die in Voigts Schicksal liegt, ist nicht ganz vom Fatum, sondern zum 
guten Teile von der Unzulänglichkeit der von uns selbst gesetzten Institutionen verursacht."20 "Das ewig Weibliche" is the German "Muttersprache" that attracts Voigt back to Germany (15). It is also the ubiquitous uniform with which Zuckmayer weds him before accomplishing the "Unbeschreibliche" through the publicly demonstative technique of drama.

With the Hauptmann von Köpenick, Zuckmayer presents the absurdity of circumstances facing the German people mid-way between the collapse of the stock market in 1929 and Hitler's Machtergreifung of 1933. In his essay, "The Stage is all the World," Northrop Frye links the shift in critical emphasis from Shakespeare's Hamlet to King Lear with the "existentialist movement that grew so rapidly after the French Resistance, when it was fashionable to speak of existence as absurd." 21 Zuckmayer's dramaturgical conflict with the resurgence of Prussian absolutism finds expression in Voigt's dilemma. Voigt symbolizes the German people who, threatened with exclusion from politics by the ancient forces of military authoritarianism, enters into the awkward position of having to protect its autonomy by donning the cloak of its traditional military opponent. Zuckmayer's dramaturgical statement against the gathering threat of the NSDAP shows the same avowal of the absurdity of existence later embraced by the Existentialists:

Absurd meant among other things that the providential God who kept gimmicking his way through human history to some kind of future happy ending was as dead as anything that had never been alive can be. It also expressed what Browning summed up a century earlier in the phrase 'There may be heaven; there must be hell.' Justice and freedom may exist somewhere or somehow; Hitler and Stalin are right there. The world-stage of fools in King Lear, then, is the theater of the Absurd, where no hidden benevolent design becomes manifest, where rebellion, obedience, courage, loyalty, acceptance or rejection of religious belief, all seem to be without direction in a world set up largely to benefit the Gonerils and the Cornwalls. ${ }^{22}$ 
Voigt's self-directed anagnorisis by means of the mirror he requests in the closing scene of the Hauptmann von Köpenick is the recognition of the absurdity in his attempt to overcome societal exclusion by assuming the cloak of the forces barring his entrance.

On the broadest range of thematic levels, Carl Zuckmayer repeats the Hauptmann von Köpenick's central dramatic conflict symbolizing the historical struggle of the German people for its sovereignty against military absolutism. Through Zuckmayer's structural transformation and synthetic combination of varying styles, the conflict between Voigt and the bureaucracy becomes anciently traditional, highly contemporary and historically relevant all at once. Zuckmayer elevates the ancient Greek dramatic theme of the conflict between chaos and cosmos to the peak of tension. Voigt struggles to assert his natural right to existence against a military bureaucratic order that blindly condemns him to a fate of societal exclusion. Zuckmayer contemporizes the conflict by attracting attention to the relationship between myth and history. He objectifies myth by relegating it expressly to the theatrical realm of fantasy - the realm inherently separate from the sphere of public and political activity. His objectification of myth serves as a point of reference from which the objective audience may free itself from subjection to the ideological influences of the times. Zuckmayer restores his audience to its active social critical capacity through his concentration of the societally critical function of his Volksstück upon the most urgent problem of his day: the threat of the German people's returning subjection to military-absolutist domination. He addresses his work to the people as a critically sovereign body in direct contradiction to National Socialist appeals to the instincts of the mass. The struggle between Voigt and the forces of bureaucracy is the ongoing political conflict between the German people and the forces of military 
absolutism. It is the struggle of humanity for the assertion of its ideal against the machinery of repeated subjugation. On the rudimentary level, it is the individual's struggle for autonomy against the compellingly subservient logic of the loyal Hoprecht: "'n Mensch bist du überhaupt nur, wenn du dich in ne menschliche Ordnung stellst!" (89). The Hauptmann von Köpenick's central conflict is humanity's attempt to assert its right to self-determination against military conceptions of what humanity should be. Through a masterful combination of the techniques of Expressionism and Neue Sachlichkeit, Zuckmayer reduces the central conflict to the subjective struggle of the individual against the blind forces of military-bureaucratic Sachlichkeit. To counter the National Socialist myth of an invisible Jewish conspiracy, Zuckmayer poses his strikingly realistic portrait of the blind machinery of oppression just waiting to be set into motion. He depicts the realism of the hollow sachlich set of institutions symbolized by a uniform just waiting for another "Voigt" to use it against the public institutions it is meant to defend. On the eve of Hitler's seizure of power, no Zeitstück could have been more überzeitlich. With amazing clarity and foresight, Zuckmayer's Hauptmann von Köpenick shows the absurdity of a nation caught in a Teufelskreis between the protection of its autonomy by military means and unresisted obedience to political expulsion.

The Teufelskreis grew to engulf the whole nation as Hitler took his mythologically founded concept of conflict onto the world stage. Yet even after the Allies and Soviets freed the world of the National Socialist myth of world domination, the conflict between the people and uniform remained. Today in 1996, humanity can still identify strongly with Voigt as it looks back with disbelief on the high cost it has paid for the maintenance of its dreams of freedom and equality in support of uniform might. 


\section{ENDNOTES} 1988) 32 .

${ }^{1}$ Werner Frizen, Der Hauptmann von Köpenick (München: Oldenbourg,

2 Armin G. Kuckhoff, Schriften zur Theaterwissenschaft, vol. 2, ed. Hochschule Leipzig (Berlin: Henschelverlag, 1960) 40.

3 Kuckhoff, 44.

${ }^{4}$ The manifest form of Zuckmayer's element of fate corresponds most closely to the latter aspects in its evolution from Moira, Lot, Ananke ("waltende Notwendigkeit"), to Ate ("Unheil") and Tyche ("Fortuna"). Kuckhoff describes Ate as "die blinde Gewalt des Schicksalhaften, wie es die griechische Gesellschaft immer wieder erleben mußte. 'A te' ist die Kraft, die entgegen aller menschlichen Voraussicht und Vorsorge das Unerwartete, die unbegreifliche Katasrophe geschehen läßt." Ate corresponds to the blind forces of fate at work in the Prussian bureaucracy. Voigt's personal fate is directly controlled by these forces, but is better expressed in terms of Tyche, for which Kuckhoff offers the following explanation: "Endlich entspricht dieser letzten, differenzierten Stufe der Entwicklung des Schicksalbegriffs die Trennung des Einzelschicksals vom Schicksal der Gesamtheit: Tyche ist (im lateinischen dann: 'Fortuna') die Göttin des Zufalls, bald freundlich, bald feindlich, im Leben des einzelnen." Kuckhoff, 45-46.

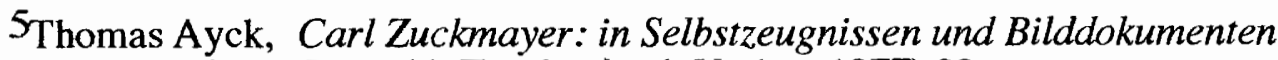
(Reinbeck bei Hamburg: Rowohlt Taschenbuch Verlag, 1977) 92.

6Hitler's presence behind the scenes in the Teufel's General is similar to that of Kaiser Wilhelm in the Hauptmann von Köpenick. Irving Fetscher describes the implications that the myth of the German race had for Nazi ideology: "Vielleicht hat pater Gaston Fessard recht, wenn er [den Antisemitismus] geschichtstheologisch als den Ausdruck der Tatsache begreift, daß der Nationalsozialismus gewaltsam hinter die christliche Ära, ja selbst hinter die der jüdischen Offenbarungsreligion zurückkehren wollte und daher genötigt war, seine 'auserwählte Rasse' gegen das 'erwählte Volk Gottes' zu stellen. Durch die Vernichtung des Gottesvolkes sollte die natürliche Überlegenheit der 'Rassenelite' bewiesen werden. Das theologische Faktum mußte beseitigt werden, um Raum zu schaffen für die Realisation des biologischen Mythos." Irving Fetscher, "Zur Kritik des sowjetmarxistischen Faschismusbegriffs," Von Weimar zu Hitler 1930-1933, ed. Gotthard Jasper (Köln und Berlin: Kiepenhauer \& Witsch, 1968) 163.

${ }^{7}$ Ernst Bloch, Erbschaft dieser Zeit: Erweiterte Ausgabe (Frankfurt am Main: Suhrkamp Verlag, 1962) 127.

${ }^{8}$ Carl Zuckmayer, Pro Domo (Stockholm: Bermann-Fischer, 1938) 78-79. 
${ }^{9}$ One of the prime sources of the myth the National Socialists adopted into doctrine originated in a satirical attack on the dictatorial methods of mass domination of Napoleon III of France. Its author was a French lawyer, Mauric Joly. His propaganda pamphlet bore the title: Dialogue aux enfers entre Machiavel et Montesquieu, ou la politique de Machiavel au XIX e siècle, par un Contemporain (Brussels: A. Mertens et Fils, 1864). "Chiefly the ideas of Machiavelli were retained in the book's later form, The Protocols of Zion. Joly applied these ideas to the technique of dominating the masses; that was his contribution." The conservative reactionary tsarist secret police, the Ochrana, dug up Joly's pamphlet. They reformulated its arguments into a myth of Jewish conspiracy, linking it to the historically factual meeting of the Jewish Zionist movement of 1897 in Basel. They integrated a childish passage dealing with a conspiracy of twelve rabbis in a Prague cemetary excerpted from Hermann Gödsche's novel, Biarritz, of 1868. A General Oryevsky of the tsarist secret police transformed the tale of the rabbis' meeting into a set of protocols. General Ratchkovsky, leader of the French Ochrana division, transferred the lines Joly has Machiavelli utter to the mouths of the fictitious group of Jewish conspirators. In this form, the pamphlet now titled the Protocols of the Wise Men of Zion became the party program for the storm troops of the counterrevolutionary movement known as the "Black Hundreds." "It was circulated widely, and in 1903 gave the signal for the Kishenev pogrom, in which several thousand Jews were massacred." Ratchkovsky laid a copy of the Protocols before Tsar Nicholas, but Minister Stolypin soon convinced him of their inauthenticity. The Protocols reached its Nazi party "discoverer,"Alfred Rosenberg, in the appendix to Sergei Nilus' book on the "Jewish Antichrist," Small signs betoken great events: The Antichrist is near at hand. "The conspirators did not need to invent anti-Semitism; no, what they did was to create anti-Semitism as a weapon in the class struggle ..." Konrad Heiden, Der Fuehrer : Hitler's Rise to Power, trans. Ralph Manheim (Boston: Houghton Mifflin Company, 1944) 5-6; 8-11; 14-16.

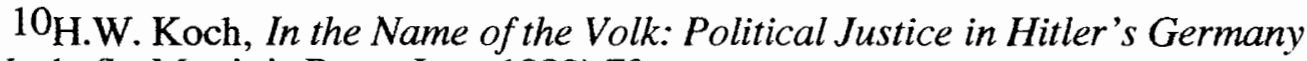
(New York: St. Martin's Press, Inc., 1989) 70.

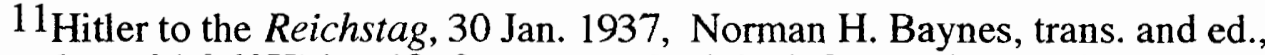
The Speeches of Adolf Hitler, (Oxford: n.p., 1942) 525, Quoted in Alan Bullock, "The Political Ideas of Adolf Hitler," The Third Reich, ed. The International Council for Philosophy and Humanistic Studies (New York: Howard Fertig, 1975) 360.

12 Koch, 69-70.

13Theodor W. Adorno, Gesammelte Schriften, vol. 2, ed. Rolf Tiedemann (Frankfurt am Main: Suhrkamp Verlag, 1974) 693.

14Walter Benjamin, "Linke Melancholie," Gesammelte Schriften III (Frankfurt am Main: Suhrkamp Verlag, 1980) 281.

15Karl Dietrich Bracher, "Einführung," Politische Justiz, by Heinrich and Elisabeth Hannover (Frankfurt: Fischer Bücherei, 1966) 9. 
16Alfred Kerr in Günther Rühle, Theater für die Republik im Spiegel der Kritik (Frankfurt am Main: S. Fischer Verlag, 1988) 1086.

17 Ludwig Marcuse in Ruhle, 1083.

${ }^{18}$ Cf. Aristotle's Poetics (1450a): "Folglich handeln die Personen nicht, um Charactere nachzuahmen, sondern um der Handlungen willen beziehen sie Charaktere ein. Daher sind die Geschehnisse und der Mythos das Ziel der Tragödie; das Ziel ist aber das Wichtigste von allem." Aristoteles, Poetik: Griechisch/Deutsch, trans. and ed. Manfred Fuhrmann (Stuttgart: Philipp Reclam jun. GmbH, 1982) 20-21.

19Johann Wolfang Goethe, Faust: Der Tragödie erster und zweiter Teil (Hamburg: Christian Wegner Verlag, 1963) 364.

${ }^{20}$ Berliner Morgenpost. Quoted in Juirgen Hein, "Zuckmayer, Der Hauptmann von Köpenick," Die deutsche Komödie vom Mittelalter bis zur Gegenwart, ed. Walther Hinck (Diisseldorf: August Bagel Verlag, 1977) 272. Also quoted above, page 23 (note 13).

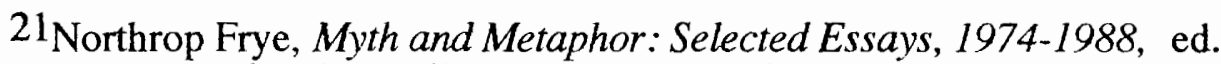
Robert D. Denham (Charlottesville and London: University Press of Virginia, 1990) 207.

${ }^{22}$ Frye, 207. 


\section{BIBLIOGRAPHY}

\section{PRIMARY SOURCES}

Zuckmayer, Carl. Als wär's ein Stück von mir: Horen der Freundschaft. Wien: S.

Fischer Verlag, 1967.

---. A Part of Myself. Trans. Richard and Clara Winston. New York: Harcourt Brace Jovanovich, Inc., 1970. Trans. of Als Wärs ein Stück von mir.

--.. Aufruf zum Leben: Porträts und Zeugnisse aus bewegten Zeiten. Frankfurt: S. Fischer, 1976.

---. Die Brüder Grimm: Ein deutscher Beitrag zur Humanität. Frankfurt am Main: Suhrkamp, 1948.

---. "Franzosenzeit (1918 bis 1930)." Blätter der Carl Zuckmayer Gesellschaft. 4.1 (February 1978): 21-25.

---. Gesammelte Werke. Frankfurt am Main: S. Fischer Verlag, 1960.

---. Der Hauptmann von Köpenick: Ein deutsches Märchen in drei Akten. Frankfurt am Main: Fischer Taschenbuch Verlag GmbH, 1993.

---. Die langen Wege. Frankfurt: S. Fischer, 1952.

---. Pro Domo. Stockholm: Bermann-Fischer, 1938.

\section{BIOGRAPHICAL WORKS}

Becker, Jochen. Carl Zuckmayer und seine Heimaten: Ein biographischer Essay. Mainz: Verlag H. Schmidt, 1989.

Grange, William. Partnership in the German Theater: Zuckmayer and Hilpert, 1925 1961. New York: Peter Lang, 1991. 
Keim, Anton Maria, ed. Exil und Rückkehr: Emigration und Heimkehr: Ludwig Berger, Rudolf Frank, Anna Seghers und Carl Zuckmayer. Mainz: Verlag H. Schmidt, 1986.

Reindl, Ludwig Emanuel. Zuckmayer: Eine Bildbiographie. Munich: Kindler, 1962.

\section{HISTORICAL INTERPRETATIONS, STUDIES \& DOCUMENTS}

Bennecke, Heinrich. Wirtschaftliche Depression und politischer Radikalismus: 19181938. München und Wien: Günter Olzog Verlag, 1970.

Berdahl, Robert M. The Politics of the Prussian Nobility: The Development of a Conservative Ideology: 1770-1848. Princeton: Princeton University Press, 1988.

Bessel, Richard. Political Violence and the Rise of Nazism: The Storm Troopers in Eastern Germany 1925-1934. New Haven \& London: Yale University Press, 1984.

Bracher, Karl Dietrich. Die Auflösung der Weimarer Republik: Eine Studie zum Problem des Machtverfalls in der Demokratie. Villingen/Schwarzwald: Ring-Verlag, 1964.

Bullock, Alan. "The Political Ideas of Adolf Hitler." The Third Reich. Ed. The International Council for Philosophy and Humanistic Studies. New York: Howard Fertig, 1975.

Craig, Gordon. The Politics of the Prussian Army: 1640-1945. New York and Oxford: Oxford University Press, 1956. 
Fetscher, Irving. "Zur Kritik des sowjetmarxistischen Faschismusbegriffs." Von Weimar zu Hitler 1930-1933. Ed. Gotthard Jasper. Köln und Berlin: Kiepenhauer \& Witsch, 1968. 163.

Goebbels, Joseph. Die Tagebücher von Joseph Goebbels: Sämmtliche Fragmente: Teil 1: Aufzeichnungen 1924-1941. Ed. Elke Fröhlich. München, New York, London, Paris: K.G. Saur, 1987.

Hannover, Heinrich and Elisabeth. Politische Justiz. Frankfurt: Fischer, 1966. Heiber, Helmut. The Weimar Republic. Trans. W.E. Yuill. Oxford, U.K. and Cambridge, U.S.A.: Blackwell Publishers, 1993.

Heiden, Konrad. Der Fuehrer : Hitler's Rise to Power. Trans. Ralph Manheim. Boston: Houghton Mifflin Company, 1944.

Hitler, Adolf. Mein Kampf. München: Zentralverlag der NSDAP, 1941.

Kater, Michael H. "Anti-Fascist Intellectuals and the Third Reich." Canadian Journal of History: Annales Canadiennes d'Histoire. 16.2 (1981): 263-77.

Kershaw, Ian. The 'Hitler Myth': Image and Reality in the Third Reich. Oxford: Clarendon Press, 1987.

Koch, H.W. In the Name of the Volk: Political Justice in Hitler's Germany. New York: St. Martin's Press, Inc., 1989.

Kramer, Gerhard F. "The Influence of National-Socialism on the Courts of Justice and the Police." The Third Reich. Ed. the International Council for Philosophy and Humanistic Studies. New York: Howard Fertig, 1975.

Krispyn, Egbert. Anti-Nazi Writers in Exile. Athens: The University of Georgia Press, 1978.

Müller, Ingo. Furchtbare Juristen: Die unbewältigte Vergangenheit unserer Justiz. München: Droemersche Verlagsanstalt Th. Knaur Nachf., 1989. 
Quigley, Hugh and Clark, R.T. Republican Germany: A Political and Economic Study. New York: Howard Fertig, 1968.

\section{RECEPTION OF THE PREMIERE AND LATER PERFORMANCES}

Goebbels, Joseph. Der Angriff: Das deutsche Abendblatt in Berlin. 12. März 1931:

1-2. Positive Microfilm. D-5300 Bonn: Mikropress GmbH, Baunscheidstraße 17; Tel. 0228-231688, January 29 - July 14, 1931.

Mews, Siegfried. Carl Zuckmayer: Der Hauptmann von Köpenick: Grundlagen und Gedanken zum Verständnis des Dramas. Frankfurt am Main, Berlin, München: Verlag Moritz Diesterweg, 1982.

Ruihle, Günther. Theater für die Republik im Spiegel der Kritik. Frankfurt am Main:

S. Fischer Verlag, 1988.

-.-. Theater in unserer Zeit. Frankfurt am Main: S. Fischer Verlag, 1976.

Scheible, Hartmut, ed. Erläuterungen und Dokumente: Carl Zuckmayer: Der

Hauptmann von Köpenick. Stuttgart: Philipp Reclam Jun., 1977.

Wille, Franz. "Zirkus Juhnke gibt nie auf." Der Spiegel. 5. 29 Jan. 96: 171-72.

\section{CRITICAL LITERATURE}

Adorno, Theodor W. Gesammelte Schriften, vol. 2. Ed. Rolf Tiedemann. Frankfurt am Main: Suhrkamp Verlag, 1974.

Aristoteles. Poetik: Griechisch/Deutsch. Trans. and Ed. Manfred Fuhrmann. Stuttgart: Philipp Reclam jun. GmbH, 1982. 
Ayck, Thomas. Carl Zuckmayer: in Selbstzeugnissen und Bilddokumenten. Reinbeck bei Hamburg: Rowohlt Taschenbuch Verlag, 1977.

Barthes, Roland. Essais Critiques. Paris: Éditions du Seuil, 1964.

Bauer, Arnold. Carl Zuckmayer. Berlin: Colloquium Verlag Otto H. Hess, 1970.

Benjamin, Walter. "Linke Melancholie." Gesammelte Schriften III. Frankfurt am Main: Suhrkamp Verlag, 1980. 279-83.

Bergson, Henri. Laughter: An Essay on the Meaning of the Comic. Trans. Cloudesley Brereton. New York: The Macmillan Company, 1917.

Berman, Russel A. "A Return to Arms: Käutner's The Captain of Köpenick (1956)." German Film and Literature: Adaptations and Transformations. New York: Methuen, 1986.

Bithell, Jethro. Modern German Literature: 1880-1950. London: Methuen \& Co. Ltd., n.d.

Bloch, Ernst. Erbschaft dieser Zeit: Erweiterte Ausgabe. Frankfurt am Main: Suhrkamp Verlag, 1962.

Engelsing-Malek, Ingeborg. "Amor Fati« in Zuckmayers Dramen. Berkeley and Los Angeles: University of California Press, 1960.

Freud, Sigmund. Jokes and their Relation to the Unconscious. Trans. James Strachey. New York: W.W. Norton \& Company Inc., 1960.

Freund, Winfried. "Einleitung." Deutsche Komödien: Vom Barock bis zur Gegenwart. München, Wilhelm Fink Verlag, 1988.

Frizen, Werner. Der Hauptmann von Köpenick. München: Oldenbourg, 1988.

Fromm, Erich. The Art of Loving. New York: Bantam Books, 1956.

Frye, Northrop. Myth and Metaphor: Selected Essays, 1974-1988. Ed. Robert D.

Denham. Charlottesville and London: University Press of Virginia, 1990. 
Glade, Henry. "Carl Zuckmayer's Theory of Aesthetics." Monatshefte. 52 (1960): 163-70.

Glauert, Barbara, ed. Carl Zuckmayer: Das Bühnenwerk im Spiegel der Kritik. Frankfurt am Main: S. Fischer Verlag, 1977.

-.-. Carl Zuckmayer: Ein Jahrbuch. Frankfurt am Main: S. Fischer Verlag, 1978.

Grimm, Reinhold. Nach dem Naturalismus: Essays zur modernen Dramatik. Frankfurt am Main: Athenäum Verlag, 1978.

Hein, Jürgen, ed. Theater und Gesellschaft : Das Volksstück im 19. und 20.

Jahrhundert. Ed. Jürgen Hein. Düsseldorf: Bertelsmann Universitätsverlag, 1973.

---. "Zuckmayer: Der Hauptmann von Köpenick." Die deutsche Komödie -- vom Mittelalter bis zur Gegenwart. Ed. Walter Hinck. Duisseldorf: August Bagel, 1977. 269-86.

Heizmann, Jürgen. Joseph Roth und die Ästhetik der Neuen Sachlichkeit. Heidelberg: Mattes Verlag GmbH, 1990.

Kaes, Anton, ed.Weimarer Republik: Manifeste und Dokumente zur deutschen Literatur 1918-1933. Stuttgart:J.B. Metzlersche Verlagsbuchhandlung, 1983. Jacobius, Arnold John. Motive und Dramaturgie im Schauspiel Carl Zuckmayers: Versuch einer Deutung im Rahmen des zwischen 1920 und 1955 entstandenen Gesamtwerkes. Frankfurt am Main: Athenäum Verlag, 1971. Kesting, Marianne. "Carl Zuckmayer - Zwischen Volksstück und Kolportage." Panorama des zeitgenössischen Theaters: 58 literarische Porträts: Revidierte und erweiterte Neuausgabe. Munich: Piper, 1969. 278-83. Koester, Rudolf. "The Ascent of the Criminal in German Comedy." German Quarterly. 43 (1970): 376-93. 
Kuckhoff, Armin G. Schriften zur Theaterwissenschaft. Vol. 2. Ed. Hochschule Leipzig. Berlin: Henschelverlag, 1960.

Mann, Otto. Deutsche Literatur im 20. Jahrhundert: Strukturen und Gestalten, Vol. 1, Strukturen. Bern und München: Franke Verlag, 1967.

Martin, Gerald P.R., ed. "Carl Zuckmayer und sein Bibliograph: Aus dem Briefwechsel mit Arnold J. Jacobius (1953-1976)." Blätter der Carl Zuckmayer Gesellschaft. 6.3 (1 August 1980): 117-57.

Mews, Siegfried. Carl Zuckmayer. Boston: Twayne, 1981.

-.-. Zuckmayer: Der Hauptmann von Köpenick. Frankfurt am Main: Diesterweg, 1978.

Paulsen, Wolfgang. "Carl Zuckmayer." Deutsche Literatur im 20. Jahrhundert: Strukturen und Gestalten. Bern: Francke, 1967. 1:302-22; 2:332-61.

Petersen, Klaus. “ ‘Neue Sachlichkeit’; Stilbegriff, Epochenbezeichnung, oder Gruppenphänomen?” Deutsche Vierteljahresschrift 56 (1982): 463-77.

Rilla, Paul. "Zuckmayer und die Uniform." Literatur, Kritik und Polemik. Berlin: Henschel, 1950. 7-27.

Rotermund, Erwin. "Zur Erneuerung des Volksstückes in der Weimarer Republik: Zuckmayer und Horváth." Volkskultur und Geschichte. Ed. Dieter Harmening, Gerhad Lutz, Bernhard Schemmel, Erich Wimmer. Berlin: Erich Schmidt Verlag, 1970. 612-33.

Ruihle, Gunter. Zeit und Theater: Von der Republik zur Diktatur: 1925-1933. Vol. 2. Berlin: Propyläen Verlag, n.d.

Sudhof, Siegfried. "Carl Zuckmayer." Deutsche Dichter der Gegenwart: Ihr Leben und Werk. Ed. Benno von Wiese. Berlin: Erich Schmidt Verlag, 1973. 6482. 
Wagener, Hans. "Mensch und Menschenordnung: Carl Zuckmayer's »deutsches Märchen« Der Hauptmann von Köpenick." Deutsche Komödien. Ed. Winfried Freund. München: Fink, 1988.

Wellwarth, George E. "Introduction." German Drama Between the Wars: an Anthology of Plays. Ed. George E. Wellwarth. New York: E,P. Dutton \& Co., Inc., 1972.

Wiese, Benno von, ed. Deutsche Dichter der Gegenwart: Ihr Leben und Werk. Berlin: Erich Schmidt Verlag, 1973.

\section{OTHER LITERARY WORKS}

Goethe, Johann Wolfang. Faust: Der Tragödie erster und zweiter Teil. Hamburg: Christian Wegner Verlag, 1963.

Grimm, Jacob and Wilhelm. "The Bremen Town Band." Jacob and Wilhelm Grimm: Selected Tales. Trans. Gilbert McKay and Philip Schofield. Harmondsworth: Penguin Books Ltd., 1982.

\section{REFERENCE WORKS}

Von Wilpert, Gero. Sachwörterbuch der Literatur. Stuttgart: Alfred Kröner Verlag, 1964. 